\title{
A (re)construção do SUS no Município de São Paulo (SP): uma avaliação sobre a incorporação da integralidade na política municipal de saúde
}

\author{
Nicanor Rodrigues da Silva Pinto
}

Tese apresentada ao Programa de Pós-Graduação em Saúde Pública da Faculdade de Saúde Pública da Universidade de São Paulo para a obtenção do título de Doutor em Saúde Pública

Área de Concentração: Serviços de Saúde Pública Orientador: Prof. Dr. Oswaldo Yoshimi Tanaka

São Paulo 
É expressamente proibida a comercialização deste documento, tanto na sua forma impressa como eletrônica. Sua reprodução total ou parcial é permitida exclusivamente para fins acadêmicos e científicos, desde que na reprodução figure a identificação do autor, título, instituição e ano da tese. 
"As contradições existem no processo de desenvolvimento de todos os fenômenos e penetram o processo de desenvolvimento de cada fenômeno, do começo ao fim. [...] Sem um conhecimento do que há de universal nas contradições, é impossível descobrir as causas gerais ou as bases gerais do movimento, do desenvolvimento dos fenômenos. Mas se não se estuda o que há de particular nas contradições, é impossível determinar essa essência específica que distingue um fenomeno dos outros, impossível descobrir as causas específicas ou as bases específicas do movimento, do desenvolvimento dos fenômenos e, em conseqüência, impossível distinguir os fenômenos e delimitar os domínios da investigação" Mao Tsé-tung ${ }^{1}$ (1937, p. 51 e 53).

\footnotetext{
${ }^{1}$ TSÉ-TUNG, M. Sobre a contradição. In: Sobre a prática e sobre a contradição. $2^{\mathrm{a}} \mathrm{ed}$. São Paulo: Editora Expressão Popular; 2001. p. 37-95.
} 


\section{AGRADECIMENTOS}

Ao professor e orientador Oswaldo Yoshimi Tanaka pela orientação dialógica e segura e pelos desafios propostos no processo de acompanhamento deste doutorado. Pelas críticas - duras e ternas -, pela franqueza, pela amizade...

A minha companheira de vida, trabalho e pesquisa Sandra Maria Spedo pelo prazer e cumplicidade do convívio. Pelas discussões, pelas críticas e por compartilharmos, ativamente, de mais este desafio não só acadêmico...

A todos os sujeitos "atores sociais" participantes desta pesquisa, identificados no texto apenas como informantes privilegiados - ou chaves - da gestão da saúde pela colaboração intencional, franca, crítica...

Aos pareceristas/revisores anônimos dos Cadernos de Saúde Pública da Fiocruz, Rio de Janeiro, que, ao aprovarem o primeiro artigo desta tese sem questionamentos, contribuíram para, indiretamente, credenciar o conjunto do trabalho...

Aos professores, membros da pré-banca, Regina Maria Giffoni Marsiglia (FCMSCSP), Antônio Carlos Gomes do Espírito Santo (UFPE), Eurivaldo Sampaio de Almeida (FSP-USP) e Francisco Antônio de Castro Lacaz (Unifesp) pelas críticas e valiosas contribuições à minuta de tese avaliada nessa fase...

Aos assistentes de pesquisa Alexandre F. Watanabe e Maíra S. Pinto pelas competentes transcrições das entrevistas e Gabriela S. Sanchez pelo apoio na versão do resumo de dois artigos para o inglês...

Ao pessoal de apoio técnico-administrativo do Departamento de Práticas de Saúde Pública da Faculdade de Saúde Pública, da Universidade de São Paulo (FSP-USP), Cidinha, Sandra, Sônia e Lívia por tornar nossas tarefas menos difíceis...

Ao pessoal de apoio técnico-administrativo do Departamento de Medicina Preventiva, da Universidade Federal de São Paulo (Unifesp) Odete, Lúcia, Luzia, Noélia, Selma e Inês pela solidariedade e pronto atendimento às nossas demandas...

Ao pessoal da Comissão de Pós-Graduação da FSP-USP, Cidinha, Vânia e Angela pelo apoio e orientações em relação aos procedimentos e normas da instituição...

Aos meus filhos Maíra e Rubens e aos filhos de minha companheira, Gabi e Daniel, pela torcida e solidariedade, bem como pela (in)compreensão das muitas ausências... 


\section{RESUMO}

Antecedentes. Alguns princípios e diretrizes organizativas do Sistema Único de Saúde (SUS) têm sido mais freqüentemente avaliados como a descentralização da gestão, a participação e controle sociais e a extensão de cobertura. A integralidade da atenção à saúde se destaca como um de seus princípios pouco estudado, particularmente no que se refere à sua dimensão sistêmica como a incorporação desse princípio na política e na gestão da saúde no âmbito municipal. Objetivo. Esta pesquisa foi desenvolvida com o objetivo de avaliar se e como a integralidade na assistência à saúde foi incorporada nas políticas de saúde priorizadas e implementadas no processo de (re)construção do SUS no Município de São Paulo (SP), no período de 2001 a 2008. Métodos. A estratégia metodológica utilizada foi a do estudo de caso, utilizando-se como dados e informações coletadas junto a distintas fontes de evidência: (a) atores sociais privilegiados, envolvidos no processo de gestão ("informantes-chaves"), por meio de entrevistas; (b) documentos de gestão (leis, decretos, portarias, normas técnicas, relatórios de gestão, atas de reunião); e (c) observação participante, desenvolvida em espaços institucionais e instâncias políticoadministrativas do SUS no município. A análise da incorporação da integralidade da assistência à saúde foi realizada prioritariamente nas dimensões da política de saúde e da gestão do sistema de saúde. Resultados. São apresentados três artigos formatados com recortes temáticos dos resultados da pesquisa e que pudessem ter consistência e densidade suficientes para serem submetidos a periódicos do campo da Saúde Pública/Coletiva. Os artigos elaborados são: (1) "Política de saúde e gestão no processo de (re)construção do SUS em município de grande porte: um estudo de caso de São Paulo, Brasil”. Cadernos de Saúde Pública, Rio de Janeiro, v.25, 2009 (No prelo); (2) "O desafio da direção única no Sistema Único de Saúde (SUS) em município de grande porte: o caso de São Paulo, Brasil”. Saúde e Sociedade, São Paulo (encaminhado - não avaliado); e (3) "AMA (assistência médica ambulatorial): uma 'inovação' assistencial ou uma estratégia para 'limpar filas' de portas de prontos-socorros?" (formatado visando a revista Physis - ainda não encaminhado).

Considerações finais. Espera-se que os resultados e sua divulgação possam contribuir para a análise crítica do SUS no Município de São Paulo e outros município de grande porte, bem como com a identificação de elementos de reflexão, de temas para novas pesquisas, ou fornecer subsídios para a (re)formulação teóricoconceituais sobre política e gestão de sistemas de saúde e o fortalecimento do SUS.

Palavras chave: Integralidade; Integração de Serviços de Saúde; Política de Saúde, Gestão em Saúde; Sistema Único de Saúde 


\section{ABSTRACT}

Background. Some principles and organizational guidelines of the Brazilian National Health System (SUS) have been evaluated more frequently such as decentralization of management, the participation and social control and the span of coverage. The integrality of attention to health is one of the issues less analyzed, especially in terms of systemic dimension as the incorporation of such principle in the policy and management in the city scope. Objective. This research was carried out aiming at evaluating if and how the global approach of health care was incorporated in prioritized health policies and executed in the process of (re)construction of the SUS in the City of São Paulo (SP), between 2001 and 2008.

Methods. The research was performed by utilizing the methodological strategy of case study derived from the following different sources of evidence: (a) social and institutional actors as privileged performers involved in management process ("keyinformers") by means of interviews; (b) management documents and papers (laws, decrees, plans, technical specifications, management reports, minutes of meetings); (c) active observation, developed in health services and political administrative areas of the SUS in the city. The analysis of the incorporation of the global approach of health care was made mainly under the aspects of health policy and health system management. Results. Three articles comprising theme excerpts of the research results which can have enough reliability and concentration to be submitted to journals in the field of Public Health. The articles written are: (1) Health policy and management in the (re)construction process of the Brazilian National Health System (SUS) in a large municipality: a case study of São Paulo city, Brazil. Cadernos de Saúde Pública, Rio de Janeiro, v.25, 2009 (in priting); (2) The challenge of the unified health services management in the Brazilian National Health System (SUS) in a large municipality: the case of São Paulo, Brazil. Saúde e Sociedade, São Paulo (submitted - not evaluated); (3) AMA (ambulatorial health care): an "innovation" in health care or a strategy to "empty lines" at hospital gates? (written for the magazine Physis - not submitted). Final Considerations. It is expected that these results and their presentation may contribute to a significant analysis of SUS in the São Paulo city and other large municipalities, as well as identifying the elements of consideration, of subjects for new researches or provide subsidies for the theoretical and conceptual (re)organization on the policy and management of health systems and the strengthening of SUS.

Key words: Integrality; Health Services Integration; Health Management; Health Policy; Single Health System 


\section{ÍNDICE}

RESUMO 5

ABSTRACT 6

APRESENTAÇÃO 8

1. INTRODUÇÃO 14

1.1. Descentralização do SUS: avanços e insuficiências 19

1.2. Integralidade como princípio estratégico do SUS 22

1.3. Por que avaliar a integralidade no Município de São Paulo? 25

2. OBJETIVOS 30

2.1. Objetivo Geral 31

2.2. Objetivos Específicos 31

3. MÉTODOS 32

3.1. Atividades para explorar dimensões da integralidade 36

3.1.1. Política de saúde 36

3.1.2. Gestão do sistema de saúde 37

3.1.3. Organização de serviços de saúde 38

3.2. Aspectos éticos 38

4. RESULTADOS 40

4.1. Artigo 1: submetido ao periódico Cadernos de Saúde Pública 41

4.2. Artigo 2: submetido ao periódico Saúde e Sociedade 71

4.3. Artigo 3: formatado visando o periódico Physis 105

5. CONSIDERAÇÕES FINAIS 138

$\begin{array}{lr}\text { 6. REFERENCIAS } & 149\end{array}$ 


\section{APRESENTAÇÃO}

Julgo importante iniciar esta apresentação da tese com um breve registro das implicações históricas deste autor com o tema. Sou médico de formação e sanitarista por opção. Desde o início de 1985, final de minha residência médica, venho atuando profissionalmente na área de formação de pessoal da saúde em serviços públicos de saúde, seja preceptorando médicos residentes, seja supervisionando alunos de graduação. Sempre trabalhei em instituições públicas e estatais, articulando a atividade de ensino, extensão e pesquisa, na então Escola Paulista de Medicina (EPM), com a atividade de sanitarista na rede de serviços de saúde da região sudeste do Município de São Paulo. Inicialmente, na Secretaria de Estado da Saúde e, desde 1992, na Secretaria Municipal de Saúde de São Paulo, sendo que parte importante desse período com o vínculo à disposição da EPM, atual Universidade Federal de São Paulo (Unifesp).

Na graduação, realizada na então EPM, iniciei minha iniciação científica associada com o trabalho que essa instituição desenvolvia entre os povos indígenas do Parque Indígena do Xingu, Mato Grosso. Nesse período, como pesquisador de campo, cheguei a desenvolver uma observação participante com o povo Kamaiurá, o que implicou em minha permanência nessa aldeia por período de pouco mais de um mês. Embora tenha tido sucesso na tarefa para a qual tinha sido designado, não fui “convertido" - nem me tornei índio, nem tampouco antropólogo - continuo médico e sanitarista. 
Como sanitarista, de 1985 a 1992, da SES-SP e, desde 1992, da SMS-SP, sempre com um pé na Unifesp e sempre trabalhando com índios e trabalhadores - pobres, mal remunerados, desempregados e, alguns, muito organizados e combativos -, no Brasil central ou nas periferias do Município de São Paulo, acompanhei e participei de algumas lutas que resultaram no SUS. Esse povo, suas dificuldades e sua luta me fizeram acreditar, defender seu ideário e lutar mais e sempre pelo SUS. Esse foi um dos motivos consciente que me direcionaram ao doutorado e esta pesquisa no SUS, no Município de São Paulo.

Nosso processo iniciou com um desafio do orientador para negociarmos nosso préprojeto com minha companheira de doutorado, a Sandra, devido à proximidade do objeto e do campo, e formatássemos um projeto de pesquisa único para buscarmos apoio financeiro junto à Fapesp. Assim, nasceu o projeto " $O$ Processo de (Re)Construção do Sistema Único de Saúde no Município de São Paulo. Uma avaliação sobre a incorporação do princípio da integralidade na política municipal de saúde”, que foi encaminhado para a Fapesp, em junho de 2005. A partir de então, iniciamos um difícil processo de negociação de acesso ao campo, no Gabinete da SMS-SP. No meio desse processo, iniciamos outra imersão no projeto para escrevermos novos subprojetos, para o exame de qualificação de projeto, que ocorreu em fevereiro de 2006.

E, até março de 2008, imaginávamos que iríamos produzir uma tese tradicional, mas a Comissão de Pós-Graduação (CPG) do Programa de Pós-Graduação da Faculdade de Saúde Pública estava discutindo a incorporação do "novo" formato de tese, com a possibilidade de organizar os resultados em três "manuscritos". Nosso orientador, que participava desse fórum da CPG, nos colocou o desafio de apresentarmos nossa 
tese no novo formato. Aceitamos, mas como seriam as regras? Estas foram aprovadas em junho de 2008. Os "manuscritos" poderiam ter a formatação de capítulos de livro ou artigos - de revisão, inclusive, ou produto de recortes de material original da pesquisa -, desde que tivessem consistências para serem submetidos à apreciação dos "pares" e, depois, com, pelo menos, dois submetidos. E a introdução, a metodologia, as considerações finais. Poderia ser o projeto submetido ao exame de qualificação de projeto, para situar os membros da banca. Procuramos membros e trabalhadores da CPG, da Biblioteca, outras teses semelhantes. Poucas referências, nenhum modelo. Assim, foi.

No capítulo da Introdução, são contextualizados o desenvolvimento do Sistema Único de Saúde (SUS), algumas avaliações que fazíamos, orientados por nossos incômodos e explorando os problemas que nos dirigiam a dirigir nossa investigação para um princípio do sistema pouco investigado. Assim, na época, fizemos uma revisão de caráter mais instrumental para avaliar quais os pilares do sistema estavam sendo mais frequientemente avaliados. E a integralidade da atenção à saúde, que se destacava como um de seus princípios menos estudado, particularmente no que se refere à sua dimensão sistêmica como a incorporação desse princípio na política e na gestão da saúde no âmbito municipal. Por que fazer esse trabalho no Município de São Paulo? Os objetivos foram destacados, como um quase capítulo.

No capítulo dos Métodos, explicitamos um pouco nossas referências à época da formatação do projeto de pesquisa, portanto, necessariamente antes de enfrentarmos o campo, as dificuldades e resistências da gestão municipal em facilitar nossa entrada ao "campo da gestão" desse município complexo. Incorporamos pequenas modificações ao projeto inicial, para esclarecer algumas dúvidas, imprecisões ou, 
mesmo, porque tinham sido organizadas antes de enfrentarmos "a vida como ela é". Isso nos redirecionou. Algumas referências teóricas "novas", outras nem tanto, foram sendo incorporadas no processo, e isso estava aparecendo na produção dos próprios artigos. Dessa forma, a principal estratégia metodológica utilizada foi a do estudo de caso, utilizando-se distintas fontes de evidência: (a) atores sociais e institucionais privilegiados, envolvidos no processo de gestão (“informantes-chaves”), por meio de entrevistas; (b) documentos de gestão (leis, decretos, portarias, normas técnicas, relatórios de gestão e de conferência, atas de reunião, folder institucional); e (c) observação participante, desenvolvida em espaços institucionais e instâncias políticoadministrativas do SUS no município. A análise da incorporação da integralidade da atenção à saúde foi realizada prioritariamente em duas dimensões: a política de saúde e a gestão do sistema de saúde.

No capítulo dos Resultados, encontram-se os três artigos, que foram formatados com recortes temáticos dos resultados da pesquisa e que pudessem ter consistência e densidade suficientes para serem submetidos a periódicos reconhecidos do campo da Saúde Pública/Coletiva. Optamos por apresentar cada um a um periódico, desde que sua publicação estivesse saindo com regularidade. Assim, estão apresentados os três artigos produzidos, seguindo a ordem cronológica de sua finalização. O processo de (re)construção do SUS no Município de São Paulo, Brasil, foi analisado, no período de 2001 a 2008, por meio de estudo de caso, utlizando-se distintas fontes: documentos; entrevistas com informantes-chave e observação participante. O primeiro artigo intitulado "Política de saúde e gestão no processo de (re)construção do SUS em município de grande porte: um estudo de caso de São Paulo, Brasil” foi organizado visando identificar e analisar as políticas de saúde priorizadas na gestão 
2001-2004 e que tiveram sustentação política na gestão seguinte. Este artigo foi submetido aos editores do periódico Cadernos de Saúde Pública, da Fiocruz, RJ, tendo sido aprovado para publicação em 2009 (no prelo). O segundo artigo intitulado “O desafio da direção única no Sistema Único de Saúde (SUS) em município de grande porte: o caso do Município de São Paulo, Brasil” foi organizado visando avaliar movimentos, estratégias e ações dos atores institucionais, SMS-SP e SES-SP, com referência na "imagem objetivo" da integralidade, no sentido da construção de uma direção única do SUS no município. Este artigo foi submetido aos editores do periódico Saúde e Sociedade, da FSP-USP e da APSP, SP, encontra-se em processo de avaliação. O terceiro artigo intitulado "AMA (assistência médica ambulatorial): 'inovação' assistencial ou estratégia para 'limpar fila' de porta de prontosocorros?" foi organizado visando avaliar o processo de implantação do projeto de unidades de AMA e, na medida em a maioria delas foi acoplada a UBSs préexistentes, discutir essa integração de serviços de saúde na lógica da integralidade do SUS, no Município de São Paulo, no período da gestão 2005-2008. Este artigo foi formatado tendo como referência o periódico Physis, do IMS-UERJ, RJ, porém ainda não foi encaminhado.

No capítulo das Considerações Finais, busca-se percorrer as principais questões suscitadas pelos achados da pesquisa, problematizando sua consistência empírica e conceitual. Foram organizadas de forma a resgatar os recortes temáticos que nortearam e subsidiaram a elaboração dos três artigos apresentados nesta tese, bem como as principais questões problematizadas. Assim, foram problematizados problemas, insuficiências e desafios do SUS, levantados pela pesquisa no Município de São Paulo, mas que podem ser comuns a outros municípios de grande porte. 
Espera-se que os resultados e sua divulgação possam contribuir para a análise crítica do SUS no município, bem como com a identificação de elementos de reflexão, de temas para novas pesquisas, ou fornecer subsídios para a (re)formulação teóricoconceituais sobre a política e a gestão de sistemas de saúde, bem como para o próprio fortalecimento do SUS. 


\section{INTRODUÇÃO}




\section{INTRODUÇÃO}

A construção da política de saúde que resultou no delineamento do Sistema Único de Saúde (SUS) buscava a superação de problemas identificados na estrutura e na organização das ações e serviços de saúde vigentes, até a década 1980. As principais críticas às práticas hegemônicas na saúde da época podem ser assim sintetizadas: acesso restrito, na assistência médica e hospitalar, só para trabalhadores da economia formal; dicotomia institucional e de práticas, preventivo versus curativo ou rede básica versus hospital, com ações concentradas em distintos ministérios; deficiências da estrutura de financiamento; corrupção gerada pela forma pagamento, por produção (US - unidade de serviço); avaliação e controle de serviços contratados inadequados; assistência médica em crescente privatização; planejamento centralizado e restrito à tecno-burocracia (CASTRO, 1999; CARVALHO e col., 2001; SILVA, 2003).

Nesse sentido, a essência da proposta de reforma de Estado, no setor saúde, conhecida como a Reforma Sanitária brasileira, foi pactuada na $8^{\mathrm{a}}$ Conferência Nacional de Saúde e os princípios e diretrizes fundamentais do SUS foram elaborados como uma possível solução para os problemas acima referidos. A luta pela institucionalização desses princípios e diretrizes logrou êxitos importantes, com a incorporação de parte substancial do ideário dessa Conferência no texto da Constituição Federal (BRASIL, 1988) e na legislação específica, representada pelas 
denominadas "Leis Orgânicas da Saúde", a Lei nº 8.080 e a Lei no 8.142 (BRASIL, 1990a; 1990b).

São reconhecidos outros importantes avanços no processo de construção do SUS, que incluem: a incorporação do direito à saúde na legislação, a descentralização da gestão, a ampliação do acesso, a extensão da cobertura de serviços e a participação e controle sociais, que vêm ocorrendo de forma mais intensa a partir da metade da década de 1990 (LEVCOVITZ e col., 2001; CORDONI JR, 2001; CNS, 2002; BARATA e col., 2004a; SILVA, 2003).

Mas, se por um lado, foram logrados avanços institucionais significativos, por outro, também é importante reconhecer que sempre existiu resistência organizada à incorporação dessa política social pelo Estado brasileiro. Prontamente, em 1987, economistas do Banco Mundial, refletindo uma conjuntura internacional hegemonicamente neoliberal, já desqualificavam o conteúdo e a estratégia dessa política (MATTOS, 2001). Esse autor reproduz um pequeno trecho do relatório do Banco, que ele classifica de "provocativo", onde fica clara sua posição:

“(...) a abordagem mais comum para os cuidados de saúde nos países em desenvolvimento tem sido tratá-lo como um direito do cidadão e tentar prover serviços gratuitos para todos. Essa abordagem geralmente não funciona" (WORD BANK, 1987 apud MATTOS, 2001, p.40).

No Brasil, essa (re)discussão do papel do Estado atingiu, na prática, várias políticas sociais e, particularmente, a da saúde (ELIAS, 1997; COHN, 1999; COHN e col. 2002). As leis, federal e do Estado de São Paulo, que regulamentam as Organizações Sociais, inclusive na saúde, bem como as propostas do extinto Ministério da 
Administração Federal e Reforma do Estado para a gestão da saúde formulam e introduzem mudanças substanciais no SUS (BRASIL.MARE, 1998; ALMEIDA, 2000). O Plano de Assistência à Saúde (PAS), implementado no Município de São Paulo, durante o período de 1996 a 2001, também deve ser reconhecido como outra forma importante de resistência ao SUS e mesmo de contra-reforma da política de saúde brasileira (COHN e ELIAS, 1999).

Desde o início da década de 1990, o país vinha apresentando um agravamento de seu quadro de desigualdades e exclusão sociais. Nessas situações, o que geralmente se observa é uma maior demanda por serviços do campo da proteção social e da saúde, em particular. Contudo, nessa década, o que se registrou foi uma progressiva diminuição dos recursos federais destinados ao financiamento das políticas de saúde (GERSCHMAN, 2000). Nesse contexto, o recém criado SUS encontrou um terreno bastante desfavorável para sua efetivação, devendo ser considerado como um projeto ainda em construção e disputa. Alguns pesquisadores caracterizaram o contexto desse período, nos seguintes termos:

“(...) a agenda da reforma sanitária brasileira é construída na contra-corrente das tendências hegemônicas de reforma dos Estados nos anos 80, e sua implementação nos anos 90 se dá em uma conjuntura bastante adversa. Face ao novo cenário político nacional, a construção do SUS expressa essas tensões, sendo observados tanto avanços como dificuldades nos diversos âmbitos estratégicos para a implantação do SUS" (LEVCOVITZ e col., 2001, p.270).

O alinhamento do Brasil às "recomendações" do FMI e Banco Mundial tem repercutido diretamente na política de saúde. Os relatórios de avaliação e as 
propostas do Banco Mundial para o setor saúde são antagônicos à proposta do SUS. Para MATTOS (2001), era “(...) evidente o contraste entre a posição brasileira e a posição defendida, por exemplo, pelo Banco Mundial”. No entanto, o autor destacou que, mesmo com um antagonismo de fundo, essas propostas deveriam partilhar de:

“(...) algumas diretrizes comuns: a defesa da descentralização e da participação popular. O que nos leva a pensar que muitas das suas diferenças girem em torno da adesão ou não ao princípio da integralidade” (MATTOS, 2001, p.40).

Cabe registrar aqui que "descentralização" não é um conceito de consenso na literatura. Em algumas tipologias, além de "desconcentração" da gestão, esse conceito também pode assumir outros significados como "delegação" ou mesmo "privatização" direta de serviços e estabelecimentos públicos e estatais para empresas privadas (ARRETCHE, 1996; UGALDE e HOMEDES, 2005). Por outro lado, é importante ressaltar que as experiências de "participação popular" latinoamericanas, incluindo entre estas as brasileiras, não têm representado apenas democracia direta. Pelo contrário, algumas experiências têm possibilitado a cooptação de lideranças e, inclusive, de movimentos sociais por governos de distintas composições partidárias e político-ideológicas (CORREIA, 2000; GUIMARÃES, 2001). Como destaca uma das autoras, em uma breve revisão sobre o tema:

“(...) La capacidad tanto del gobierno cuanto de la participación ciudadana, frente a las responsabilidades descentralizadas, es un processo que se construye $y$ no que se adquiere automáticamente. Aún con la descentralización, el poder puede volver a las oligarquias locales; la ejecución de nuevas responsabilidades puede ser perjudicada por la carencia de 
capacidad técnica; y la participación puede ser manipulada en su capacidad de decidir y de ejercitar el control" (GUIMARÃES, 2001, p.6).

\subsection{Descentralização do SUS: avanços e insuficiências}

Dada a abrangência do conceito de acesso à saúde e suas múltiplas dimensões, alguns autores consideram que o processo de descentralização da gestão da saúde é condição necessária e impulsionadora para facilitar a acessibilidade da população aos serviços (HORTALE e col., 2000).

No Brasil, o processo de descentralização da saúde foi implementado de forma gradual e consistente na década de 1990, apoiado nas Leis Orgânicas de Saúde (BRASIL, 1990a; 1990b). Assumindo a descentralização em saúde como o processo de constituição de Sistemas Locais de Saúde, que respondam adequadamente à demanda da população e que, ao invés de se caracterizarem como sistemas isolados e autônomos, sejam elementos e elos dinâmicos de articulação regional e com o Sistema Nacional (SCATENA e TANAKA, 2001).

A concretização da diretriz da descentralização da saúde em um país, com dimensões continentais e tantas desigualdades regionais, implica em grandes desafios, tais como: não perder a unicidade de uma política de caráter nacional e respeitar a diversidade do contexto sócio econômico bem como a conformação da oferta de serviços como construção social. Nesse sentido, as Normas Operacionais Básicas (NOBs) e a Norma da Atenção à Saúde (NOAS) do SUS foram consideradas instrumentos estratégicos e fundamentais, por possibilitarem a regulação do processo 
de descentralização, tratando de aspectos relacionados a: divisão de responsabilidades, relações entre gestores, critérios e mecanismos de transferência de recursos federais para estados e municípios (LEVCOVITZ e col., 2001).

Contudo, é importante registrar também que a garantia de acesso per se, embora necessária, não é condição suficiente para garantir a resolutividade do serviço e/ou do sistema de saúde. A qualidade e a resolutividade da atenção à saúde e não apenas da atenção básica, são ainda desafios a serem enfrentados e superados no processo de implementação do SUS (LEVCOVITZ e col., 2001; SANTOS, 2004). Nesse sentido, um aumento real da resolutividade no âmbito da atenção básica, apesar de necessário, não é suficiente para melhorar a resolutividade da atenção à saúde. São necessárias também ações complementares nos níveis de maior complexidade do sistema.

Uma avaliação desse processo, no estado de São Paulo, constatou que a descentralização “(...) não tem, por si só, conseguido determinar transformações significativas no modelo assistencial existente nas regiões, repetindo, na escala municipal, erros já existentes anteriormente” (BARATA e col., 2004b). E ressaltam que, apesar da expansão de cobertura da atenção básica, por meio da implementação da estratégia do Programa de Saúde da Família, os serviços continuam apresentando baixa capacidade resolutiva, não atendendo às necessidades de saúde da população.

O processo de descentralização de gestão da saúde, em curso, tem propiciado um campo fértil à experimentação prática e instrumental em planejamento e organização de serviços de saúde. Buscam-se novos modelos e práticas que possam dar conta das diversidades presentes nos vários municípios e regiões do país. Esse cenário tem 
demandado esforços constantes no sentido do desenvolvimento e aperfeiçoamento das práticas de planejamento e programação de serviços, buscando coletivamente a construção de alternativas para operar e organizar os serviços de saúde no nível local. Novamente, o principal limite que se percebe é a ênfase, quase exclusiva, na atenção básica.

Nesse sentido, o SUS trouxe para a agenda das políticas públicas um projeto de sistema de proteção social que consagra o direito universal à saúde. Este direito, se implementado como incorporado na Constituição Federal brasileira, tenta superar a situação anterior de acesso limitado a parcelas restritas da população (BRASIL, 1988). No processo de construção do SUS, a universalização da atenção à saúde foi um dos primeiros princípios que se tentou operacionalizar para ampliar o acesso da população às ações e aos serviços de saúde. Considera-se que esse acesso, ainda que de forma diferenciada, vem sendo ampliado para parcelas significativas da população brasileira (LEVCOVITZ e col., 2001; ALMEIDA e col., 2002). Mas, para suprir serviços de saúde para a população, de forma a responder ao déficit histórico de oferta, a principal estratégia vem sendo via a expansão de serviços da atenção básica, principalmente por meio do programa de saúde da família.

Por outro lado, deve-se considerar que, embora o princípio da universalidade tenha operado mudanças importantes no plano do direito à saúde, concretamente, a universalização do acesso ainda é insuficiente e incompleta, constituindo-se em um grande desafio para o SUS, principalmente quanto a mecanismos de avaliação da resolutividade que possam desencadear estratégias alternativas de organização do sistema de saúde, seja ao nível local ou regional (ALMEIDA e col., 2002). 


\subsection{Integralidade como princípio estratégico do SUS}

Em que pesem os avanços significativos na implementação do SUS, a integralidade se destaca como sendo um princípio que não foi efetivamente incorporado na organização dos serviços e no cotidiano da atenção; provavelmente, o mais ausente ou implementado em menor grau segundo vários autores (CORDONI JR, 2001; GIOVANELLA e col., 2002; MATTOS, 2004) e destacada como um dos principais problemas do SUS, pelos gestores municipais (CONASEMS, 2005).

A integralidade constitui um dos princípios finalísticos do SUS. A Constituição Federal, em seu artigo 198, estabelece que as ações e serviços de saúde devem ser organizados de acordo com algumas diretrizes, dentre as quais o "atendimento integral” (BRASIL, 1988). E a Lei nº 8.080, em seu capítulo II, estabelece que o SUS deve ser organizado obedecendo a alguns princípios, dentre eles o da integralidade da assistência, entendido como um: “(...) conjunto articulado e contínuo das ações e serviços preventivos e curativos, individuais e coletivos, exigidos para cada caso em todos os níveis de complexidade do sistema” (BRASIL, 1990a).

Por outro lado, é importante considerar que o princípio da integralidade está intimamente articulado com os princípios da universalidade e da eqüidade. Inclusive, essa relação de indissociabilidade ou entrelaçamento entre eles, já foi caracterizada como um "tríplice signo da Reforma Sanitária” (CECILIO, 2001). Para esse autor, "não há integralidade e eqüidade possíveis sem a universalidade do acesso garantida" e, ainda, se a integralidade fosse incorporada na rede de serviços de 
saúde, em todas as suas dimensões, teria o potencial de "subsumir a eqüidade" (CECILIO, 2001).

Dado o significado do termo integralidade, a dimensão que esse princípio pode assumir na organização das ações e serviços é bastante ampla e complexa. Assim, apesar de um núcleo comum, observa-se uma variação na profundidade com que diversos autores abordam esse tema.

Um trabalho acadêmico, centrado no tema da integralidade em saúde, situa seus antecedentes na discussão dos modelos de organização das práticas em saúde. Nesse sentido, a integralidade da atenção estaria incorporada no movimento histórico das concepções do processo saúde-doença, na concepção integral da saúde. Em sua sistematização sobre o tema, essa autora identifica cinco dimensões conceituais de integralidade: a apreensão do coletivo, a concepção da abordagem da totalidade biopsicossocial do indivíduo, a integração sanitária, a apreensão do conjunto de problemas de saúde de uma população definida e o compromisso com a intervenção sobre os determinantes dos processos de saúde e doença (KEHRIG, 2001).

Para outros, a integralidade seria mais do que um princípio do SUS é uma "bandeira de luta", uma "imagem objetivo", ou seja, tem um objetivo de referência onde se deseja chegar, é polissêmica e indica a necessidade de transformação da realidade. Esse autor destaca três sentidos da integralidade: traço de uma boa medicina, como atributos das práticas de saúde; modo de organizar os serviços de saúde; e orientadora de políticas de saúde ou de respostas governamentais a certos problemas de saúde (MATTOS, 2001). 
Outro autor atribui à integralidade a importância do princípio que poderia ser uma estratégia de se contrapor às dicotomias ou separações entre ações de promoção da saúde e preventivas versus ações curativas e reabilitadoras, que seriam a base da justificação técnica do projeto neoliberal para a saúde (MENDES, 1993). Para esse autor, a aplicação do princípio da integralidade da atenção à saúde implica, necessariamente, no reconhecimento da:

“(...) unicidade institucional dos serviços de saúde para o conjunto de ações promocionais, preventivas, curativas e reabilitadoras e que as intervenções de um sistema de saúde sobre o processo saúde-doença conforma uma totalidade que engloba os sujeitos do sistema e suas inter-relações com os ambientes natural e social” (MENDES, 1993, p.149-50).

Considerando o caráter polissêmico do termo, a integralidade também é conceituada como sendo uma:

“(...) ação social resultante da permanente interação dos atores na relação demanda e oferta, em planos distintos de atenção à saúde (plano individual onde se constroem a integralidade no ato da atenção individual e o plano sistêmico - onde se garante a integralidade das ações na rede de serviços), nos quais os aspectos subjetivos e objetivos sejam considerados" (PINHEIRO, 2001, p.65).

Dessa forma, para essa autora, uma dimensão estaria relacionada ao "cuidado", considerando a incorporação de tecnologias assistenciais, e outra ao "sistema", enquanto política. 
A importância de se identificar e trabalhar a integralidade em distintas dimensões é fundamental para uma discussão no âmbito do planejamento e da organização das práticas e serviços de saúde. Nesse sentido, CECÍlIO (2001) caracteriza essas dimensões, denominando-as de "integralidade focalizada" e "integralidade ampliada”. A primeira delas se daria no espaço singular de cada serviço de saúde, através do esforço da equipe de saúde de traduzir e atender às necessidades de saúde de uma dada população. E, a segunda, a integralidade em sua dimensão "macro", seria fruto da articulação de cada serviço com uma rede mais complexa, incluindo outros serviços, instituições e setores.

\subsection{Por que avaliar a integralidade no Município de São Paulo?}

Em revisão bibliográfica realizada, foram encontrados poucos estudos abordando a questão da integralidade. Além da produção teórico-conceitual do grupo do LAPPISLaboratório de Pesquisa sobre Práticas de Integralidade em Saúde, a maioria dos estudos é constituída por dissertações e teses acadêmicas. Essa produção tem enfatizado temáticas distintas envolvendo a discussão teórico-conceitual e aspectos específicos da integralidade (FURTADO, 1995; JULIANI, 1996; LOPES, 1996; KEHRIG, 2001; MAEDA, 2002). Poucos estudos têm abordado a integralidade em seu plano sistêmico (FERREIRA, 2003; SILVA, 2004).

Devem-se considerar alguns estudos que, embora desenhados para caracterizar a descentralização e/ou a municipalização da saúde em municípios brasileiros selecionados, fornecem indicações sobre possíveis condicionantes do processo de 
construção do SUS no país. Um desses condicionantes é relacionado à autonomia financeira e de pessoal qualificado no município para que este incorpore, além da atenção básica, a integralidade da atenção à saúde em sua dimensão sistêmica (VIANA e col., 2002). São identificados, ainda, outros condicionantes relacionados com o porte do município, bem como sua capacidade de investimento (arrecadação tributária) (ARRETCHE e MARQUES, 2002; VIANA e col., 2002).

Alguns trabalhos têm centrado a discussão da integralidade restrita ao âmbito da atenção básica. Essa ênfase parece estar associada à política implementada pelo Ministério da Saúde, na última década, de priorizar a atenção básica. Essa avaliação foi expressa por alguns autores de outra forma: “(...) o princípio da integralidade, que garante o acesso da população a todos os níveis de atenção à saúde, não pode em nome da universalidade da Atenção Básica, ser 'esquecido'” (MARQUES e MENDES, 2002).

Nesse sentido, parece-nos importante e oportuno realizar novos estudos sobre a integralidade no SUS, em suas distintas dimensões. Destacamos a necessidade de se abordar a integralidade em sua dimensão "ampliada", aspecto ainda pouco estudado. Compartilhamos com a preocupação expressa por alguns autores de que precisamos “(...) deslocar nosso foco de atenção da 'atenção primária’ como lugar privilegiado da integralidade. Aliás, integralidade não se realiza nunca em um serviço: integralidade é objeto de rede" (CECÍLIO, 2001).

Quando se propôs a realização desta pesquisa no Município de São Paulo (SP), advogava-se que esse município reunia as condições básicas e necessárias para tanto. Em 2001, com uma nova gestão municipal, São Paulo tinha retomado o processo de 
(re)construção do SUS; no início, na condição de gestão plena da atenção básica e, desde junho de 2003, sendo habilitado na condição de gestão plena do sistema municipal de saúde (BRASIL.MS, 2003).

Desde então, a SMS-SP passou a ser gestora única ou exclusiva de cerca de $92 \%$ de um total de 648 estabelecimentos de saúde públicos e estatais sediados na capital. A maioria dos demais, embora estivessem sob regime formal de gestão compartilhada com a SES-SP, foram mantidos sob a gerência estadual, inclusive alguns serviços e estabelecimentos de saúde de média e de alta complexidades tecnológicas (Departamento de Informática do SUS. Cadastro Nacional de Estabelecimentos de Saúde. http://www.cnes.datasus.gov.br, acessado em 15 set. 2005).

Essa situação possibilitava a oportunidade de se investigar o processo de municipalização em curso nesse município, com foco no referencial do princípio da integralidade e sua articulação com o princípio da universalidade do SUS, como sugeriram alguns autores (BARATA e col., 2004a).

Nesse contexto, a realização da pesquisa no Município de São Paulo foi considerada importante, viável e estratégica. Mas, foram ponderados também os desafios e os riscos para se desenvolver uma pesquisa, com forte componente qualitativo, envolvendo as áreas da política de saúde e da gestão do SUS, nessa cidade. Isso, em razão das características superlativas de São Paulo, como: ser o maior município do país, a maior capital de estado e sede da maior região metropolitana; possuir a maior rede de estabelecimentos e serviços de saúde do país; ter uma Secretaria Municipal de Saúde grande, complexa, portadora de estrutura administrativa com história e cultura organizacional. Somava-se a essas singularidades, o fato da rede municipal de 
saúde ter experimentado montagens e desmontagens de distintos modelos assistenciais e de gestão em saúde, desde 1989, incluindo o extinto PAS.

Por outro lado, a existência - em quantidade e diversidade - de serviços e estabelecimentos públicos de saúde, com os mais variados perfis de complexidade assistencial, ainda que, historicamente, desarticulados ou não integrados, foram consideradas condições necessárias para a pesquisa. Sem elas, poder-se-ia advogar que a integralidade seria apenas mais um objeto de desejo idealizado, mas sem viabilidade por não dispor dos serviços mínimos necessários para torná-la realidade. Dispondo dessas condições mínimas e a partir delas, a gestão municipal da saúde comprometida com o ideário do SUS - e os próprios pesquisadores -, poderiam explorar várias possibilidades de políticas, arranjos assistenciais ou de gestão, referenciados no princípio da integralidade. Por fim, um argumento econômico favorável aos defensores de políticas públicas como o SUS, São Paulo continuava sendo um importante centro comercial e industrial, com grande capacidade fiscal e, conseqüentemente, de investimento e com relativa autonomia financeira em relação à parcela do financiamento do Ministério da Saúde.

Outro aspecto relevante para a realização da pesquisa proposta, no Município de São Paulo, tinha a ver com seu potencial de chamar a atenção dos gestores municipais para a questão estratégica da integralidade no processo de (re)construção do SUS no município. Dessa forma, esperava-se que seus achados e discussões pudessem contribuir para o aprofundamento da reflexão, na intervenção propriamente dita e mesmo em uma potencial "correção de rumos", como sugerido por alguns autores (GIOVANELLA e col., 2002). 
Mesmo considerando a polissemia do termo, bem como a interdependência de ações para a efetivação do princípio da integralidade no SUS, assumimos, neste estudo, um conceito operacional de integralidade, relacionado ao modo de organizar serviços de saúde. Dessa forma, optamos por trabalhar com a integralidade da assistência à saúde como a continuidade do cuidado em saúde, garantida pelo acesso a serviços, que incorporam distintas densidades tecnológicas, também classificados por alguns autores como de distintos níveis de complexidade do sistema de saúde.

Nessa perspectiva, também foi usado o conceito de "integração sanitária", que diz respeito a ações e serviços do setor saúde e consiste em “agrupar órgãos díspares dentro de um plano e um programa de ação comuns; e reuní-los em um serviço que funcione como um todo harmônico sob uma chefia única” (RAMOS, 1972, p. 6). Destaca-se que há afinidade conceitual entre este e o princípio da integralidade do SUS, expresso no artigo $7^{\circ}$, inciso II da Lei n ${ }^{\circ} 8.080$ (BRASIL.MS, 1990a).

Por fim, vale registrar, e antes da primeira negociação visando o acesso dos pesquisadores ao campo - espaços de gestão - com interlocutores da Secretaria Municipal de Saúde de São Paulo (SMS-SP), as questões que norteavam o processo avaliativo, deste projeto/pesquisa, eram assim formuladas: “A política municipal de saúde tem estimulado e/ou facilitado a incorporação da integralidade da atenção nas ações e serviços de saúde do SUS, no Município de São Paulo?" e "Como o princípio da integralidade vem sendo incorporado na gestão do sistema municipal de saúde, em um município de grande porte como o Município de São Paulo?” 


\section{OBJETIVOS}




\section{OBJETIVOS}

\subsection{Geral}

- Identificar e avaliar a incorporação da integralidade na assistência à saúde em políticas de saúde priorizadas e implementadas, no processo de (re)construção do SUS, no Município de São Paulo (SP).

\subsection{Específicos}

Os objetivos específicos da pesquisa são avaliar:

- coerência entre o princípio da integralidade do SUS e políticas implementadas na gestão da saúde, no Município de São Paulo;

- estruturas, estratégias e movimentos utilizados na gestão da saúde, no Município de São Paulo, que estimulam e/ou facilitam a incorporação da integralidade do SUS, no âmbito da política municipal de saúde. 


\section{MÉTODOS}




\section{MÉTODOS}

O delineamento deste estudo foi o de uma pesquisa avaliativa, tendo como referência teórica a avaliação de processo, particularmente de uma política pública (WEISS, 1998; DRAIBE, 2001). Desde seu início, foi assumido como um estudo de caráter, interesse, objeto, métodos e prazos acadêmicos. Dessa forma, se pretendeu diferenciá-la de uma avaliação típica, com as características de: caráter permanente, envolvimento direto dos serviços e gestores do Sistema, métodos e prazos mais flexíveis ou negociados.

Nesse sentido, pretendeu-se entender e explicar as relações entre as "intenções", construídas e expressas na fase da formulação das políticas, e as "ações", que são expressão da vida real e estão presentes na fase de implementação das políticas (VIANA, 1996).

O objeto da pesquisa foi uma avaliação de políticas de saúde no Município de São Paulo (SP), no período de 2001 a 2008, com ênfase na análise se e como a integralidade da assistência à saúde vinha sendo incorporada na política municipal de saúde. Dessa forma, foram contempladas as experiências de duas gestões municipais: a primeira (2001-2004), que desencadeou o processo de (re)construção do SUS nesse município, e a segunda (2005-2008), que trazia propostas de novas mudanças na gestão da política municipal de saúde. 
Optou-se por desenvolver a pesquisa usando a estratégia do "estudo de caso", que é caracterizado como um estudo empírico que investiga um fenômeno contemporâneo complexo, em seu contexto, especialmente quando os limites entre o fenômeno e o contexto não estão claramente definidos (MINAYO, 1996; DENIS e CHAMPAGNE, 1997; YIN, 2005). O estudo de caso tem como objetivos, de um lado, a tentativa de compreender o fenômeno em estudo e, por outro, a tentativa de desenvolver teorias mais gerais; nesse sentido, articula questões empíricas e teórico-conceituais (DESLANDES e GOMES, 2004). Em função dessas características, essa estratégia tem sido freqüentemente utilizada em pesquisas sobre política e administração públicas e, em particular, no campo da saúde (GODOY, 1995; VIANA, 1996; WEISS, 1998; DESLANDES e GOMES 2004; YIN, 2005).

Para a exploração do objeto de estudo, foram utilizadas as seguintes fontes de evidência: (a) atores sociais e institucionais privilegiados do processo de gestão (“informantes-chaves"), por meio de entrevistas; (b) documentos de gestão; e (c) observação participante de autores/pesquisadores. Foram realizadas reuniões com gestores/assessores da Secretaria Municipal de Saúde de São Paulo (SMS-SP), com o objetivo de apresentar a proposta da pesquisa, identificar interlocutores e solicitar documentos, dados e relatórios existentes.

Os entrevistados foram: três gestores da SMS-SP; quatro assessores técnicos de Gabinete da SMS-SP e um da SES-SP; dois coordenadores regionais; e um supervisor técnico. Essas entrevistas foram individuais de tipo não-estruturadas, com uso de roteiro básico [com cinco temas para serem explorados]. Os objetivos da pesquisa eram apresentados aos entrevistados, que falavam livremente sobre os mesmos por cerca de 40 minutos. Quando temas de interesse eram abordados nessa 
fala inicial, os autores presentes estimulavam o tema explorando detalhes. As entrevistas foram realizadas por, pelo menos, dois dos autores, sendo que todas foram gravadas e, posteriormente, transcritas.

Os documentos de gestão analisados foram: documentos oficiais (leis, decretos, portarias, relatórios de gestão e de conferências, atas de reuniões) publicados ou disponibilizados em: Diários Oficiais; sítios institucionais; documentos internos, mesmo que em versões preliminares; e publicações de sujeitos da pesquisa.

A observação participante foi desenvolvida, com implicação de tipo "periférico" (LAPASSADE, 2005), por dois pesquisadores/autores (NRSP e SMS) em reuniões plenárias do Conselho Municipal de Saúde, em Conferências Municipais de Saúde, em visitas a serviços e estabelecimentos de saúde da SMS-SP e em conversas com gestores e técnicos da gestão. As informações obtidas por meio dessa técnica foram usadas como forma diferenciada, nos artigos, tanto destacando algumas como "frases", quanto apenas para de validar informações das outras fontes de evidência, em uma triangulação de fontes e técnicas.

Foram considerados alguns critérios propostos por GIOVANELLA e col. (2002) para a avaliação da integralidade na gestão de sistemas municipais de saúde, bem como outras propostas para a avaliação de serviços e programas de saúde (MERHY, 1994; TANAKA e MELO, 2001). Os atributos necessários selecionados foram organizados em duas dimensões de integralidade priorizadas: política de saúde e gestão do sistema de saúde (Quadro 1). 
Quadro 1. Dimensões da integralidade e atributos necessários selecionados.

\begin{tabular}{|c|c|}
\hline DIMENSÃO & ATRIBUTOS NECESSÁRIOS \\
\hline $\begin{array}{l}\text { Política de saúde } \\
\text { orientação para o setor saúde e a } \\
\text { participação social }\end{array}$ & $\begin{array}{l}\text { - fóruns ou instâncias intra-setoriais } \\
\text { - instâncias de controle social do SUS-SP }\end{array}$ \\
\hline $\begin{array}{l}\text { Gestão do sistema de saúde } \\
\text { articulação entre distintos campos } \\
\text { de ação (dimensão assistencial) }\end{array}$ & $\begin{array}{l}\text { - instâncias de articulação e/ou integração entre a } \\
\text { SMS-SP e a SES-SP } \\
\text { - desenho estrutural, organizacional e de regulação } \\
\text { do SUS-SP } \\
\text { - instrumentos de gestão do SUS-SP }\end{array}$ \\
\hline
\end{tabular}

\subsection{Atividades para explorar dimensões da integralidade}

$\mathrm{Na}$ etapa exploratória das dimensões da integralidade da atenção à saúde, inicialmente, foi proposta uma seqüência lógica de atividades visando o desenvolvimento de algumas variáveis.

\subsubsection{Política de saúde}

Para se avaliar a incorporação da integralidade em um sistema de saúde, era importante considerar também que a percepção dos distintos atores implicados no processo político-institucional podia ajuda a estimar o "grau de implantação" dessa política (HARTZ e CONTANDRIOPOULOS, 2004).

As instâncias de participação e controle social do SUS-SP (Conselho e Conferência Municipais de Saúde) foram avaliadas, inicialmente, por meio de atas, documentos e relatórios do período 2001 a 2008. Essa etapa permitiu a seleção de atributos/variáveis para o momento seguinte: observação direta de reuniões dessas instâncias, durante o ano de 2006-2007. 


\subsubsection{Gestão do sistema de saúde}

Esta dimensão foi avaliada por meio de atributos necessários que permitiram identificar a integração organizacional e programática entre os campos de ação, concentrando-se na dimensão assistencial do sistema. Para tanto, foram considerados preferencialmente a organização da assistência médica (com a possibilidade de funcionamento hierarquizado e de trabalho em rede) e os mecanismos de regulação do sistema. Considerava-se, ainda, que o SUS-SP era composto por uma rede de serviços de saúde de todos os níveis de complexidade sob a gestão da SMS-SP e, também, da SES-SP.

No componente das instâncias de articulação elou integração entre a SMS-SP e a SES-SP, os dados necessários foram coletados a partir de: atas e documentos existentes, do período 2001 a 2008.

A estrutura organizacional de SMS-SP, bem como todas as organizações vinculadas ao SUS-SP foram avaliadas a partir de dados coletados em: documentos oficiais (leis, decretos, portarias, resoluções, comunicados e normas técnicas) obtidos no Diário Oficial do Município de São Paulo, na página institucional da SMS-SP disponível na rede web e em arquivos públicos.

O plano e a agenda municipais de saúde foram pesquisados para avaliar ações e projetos efetivamente implementados. Os dados necessários para essa avaliação foram coletados por meio de: documentos oficiais (portarias, resoluções e normas técnicas) obtidos no Diário Oficial do Município de São Paulo, na página institucional da SMS-SP na rede web e em arquivos públicos; e entrevistas com atores institucionais. 


\subsubsection{Organização de serviços de saúde}

Esta dimensão foi operacionalizada prioritariamente no âmbito de um território selecionado (subprojeto específico - SMS), visando avaliar a questão da garantia de acesso adequado e oportuno a recursos tecnológicos necessários para a resolução dos problemas de saúde desse território. Para tanto, a referência utilizada foi a existência de oferta organizada de ações e serviços de saúde, por vezes contempladas em documentos da área da regulação da atenção à saúde, prevendo a garantia de referência e contra-referência entre os serviços ambulatoriais e hospitalares; e incluindo procedimentos nos distintos níveis de complexidade, com fluxos e percursos definidos.

\subsection{Aspectos éticos}

Considerando-se que o objeto da presente pesquisa foi uma avaliação de processo da política de saúde no município de São Paulo e, embora com potencial de desvelar e expor posições e/ou referenciais conflitantes entre os vários atores sociais atuantes na política de saúde do município, a pesquisa não apresentava riscos para seus participantes.

As principais fontes de evidência e informação utilizadas foram documentos de gestão, observação direta e participante e entrevistas de agentes vinculados ao Estado brasileiro, nesse sentido em função pública, no SUS e no município. 
Previamente à realização das entrevistas com informantes-chaves, representantes de instâncias de formulação e controle da política de saúde (gestores, trabalhadores da saúde, usuários), foi fornecida uma declaração específica - o Termo de Responsabilidade -, assegurando seu anonimato e que as informações fornecidas seriam utilizadas exclusivamente em trabalhos de cunho acadêmico vinculados à pesquisa. Os atores sociais privilegiados do processo de gestão ("informanteschaves") selecionados para as entrevistas individuais foram devidamente esclarecidos sobre os objetivos da pesquisa e convidados a participar. Aos que aceitaram, foi solicitado seu consentimento para o uso das informações fornecidas, por intermédio de formulário específico - o Termo de Consentimento Livre e Esclarecido.

$\mathrm{O}$ projeto de pesquisa, ao qual este subprojeto estava vinculado, intitulado “ $O$ processo de (re)construção do Sistema Único de Saúde no município de São Paulo. Uma avaliação sobre a incorporação do princípio da integralidade na política municipal de saúde” já foi submetido aos Comitês de Ética em Pesquisa: (a) da Faculdade de Saúde Pública (COEP/FSP-USP - parecer favorável em 10/8/2005); e (b) da Secretaria Municipal de Saúde de São Paulo (CEP/SMS - parecer favorável em 27/9/2005). 
4. RESULTADOS 


\section{RESULTADOS}

\subsection{Artigo 1: submetido ao periódico Cadernos de Saúde Pública}

O artigo "Política de saúde e gestão no processo de (re)construção do SUS em município de grande porte: um estudo de caso de São Paulo (SP), Brasil” foi formatado e apresentado aos editores do periódico Cadernos de Saúde Pública, que é uma publicação da Escola Nacional de Saúde Pública 'Sérgio Arouca', da Fundação Osvaldo Cruz, Rio de Janeiro (RJ).

\section{Referências editoriais do periódico e comunicação autor(es) - editor}

- Artigos

a) Texto e referências - máximo de 6.000 palavras

b) Referências - numeradas consecutivamente, sobrescrito, em arábico e em ordem de citação no manuscrito

c) Resumo - máximo de 180 palavras

d) Palavras chave -3 a 5

- Envio do artigo para o periódico

15 de agosto de 2008

- Situação que se encontra o artigo

4 de novembro de $2008 \rightarrow$ Manuscrito - Aprovado

12 de janeiro de $2009 \rightarrow$ Prova de Prelo-Aprovada 
Política de saúde e gestão no processo de (re)construção do SUS em município de grande porte: um estudo de caso de São Paulo, Brasil

Health policy and management in the (re)construction process of the Brazilian National Health System (SUS) in a large municipality: a case study of São Paulo city, Brazil

Nicanor R. S. Pinto ${ }^{1,2}$; Oswaldo Yoshimi Tanaka ${ }^{1}$; Sandra Maria Spedo ${ }^{1,2}$

${ }^{1}$ Faculdade de Saúde Pública, Universidade de São Paulo

${ }^{2}$ Departamento de Medicina Preventiva, Universidade Federal de São Paulo

\section{Correspondência:}

Nicanor R. S. Pinto

Departamento de Medicina Preventiva - Universidade Federal de São Paulo Rua Botucatu 740

São Paulo, SP

04023-062, Brasil

nicanor@medprev.epm.br 


\section{Resumo}

O processo de (re)construção do SUS no Município de São Paulo, Brasil, foi analisado, no período de 2001 a 2008, por meio de estudo de caso, utlizando-se distintas fontes: documentos; entrevistas com informantes-chaves e observação participante. Os conceitos de política de saúde e de gestão em saúde foram utilizados na qualidade de categorias analíticas. Foram selecionadas e analisadas apenas políticas priorizadas pela gestão iniciada em 2001 e que tiveram sustentação até 2008. Discutem-se desafios para a (re)construção do SUS no município relacionados com o contexto político-institucional e com mudanças de estrutura implementadas. As reorganizações da Secretaria Municipal de Saúde de São Paulo propiciaram a constituição e manutenção de dois subsistemas municipais, um hospitalar e outro ambulatorial. Negociações entre os governos municipal, estadual e federal não avançaram para que o município assumisse a gestão de fato de todo sistema de saúde, constatando-se a coexistência de três subsistemas públicos de saúde paralelos: dois municipais e um estadual. A sustentação política do Programa Saúde da Família foi associada ao fato de que esse programa não se constituiu como marca da primeira gestão municipal e, ainda, de ser política prioritária e estimulada pelo governo federal.

Palavras chave: Política de Saúde; Gestão em Saúde; Sistemas de Saúde; Sistema Único de Saúde 


\begin{abstract}
The Unified National Health System (SUS) was analyzed in São Paulo city from 2001 to 2008 by a case study method. The main analytical variables were: health policy and management. The priority policies implemented in 2001 with sustainability until 2008 were the analytical focus in this study. The challenge to (re)construct the SUS in the city was the main stream of the analysis and it was done in relation to the political context, organizational and functional changes. The city health secretariat reorganization resulted in two different health subsystem: one hospital based and another in ambulatory and primary care. The commitment of the city, state and national government levels were not enough to the municipal level to assume the management of the city health system as a whole. The lack of negotiation among government levels resulted in three health subsystem almost autonomous: two on municipal and one on state responsibility. One of the main strategies, the Family Health Program, was sustained mainly as a national policy and strengthened by the federal government and for not being a municipal government trade mark.
\end{abstract}

Key words: Health Policy; Health Management; Health Systems; Unified Health System in Brazil 


\section{Introdução}

No Brasil, a implantação do Sistema Único de Saúde (SUS) em municípios de grande porte continua representando um complexo desafio. Embora o Município de São Paulo tenha iniciado um processo de alinhamento ao ideário do SUS no final da década de 1980, este foi interrompido no início da década seguinte, diferentemente do que ocorreu em outras capitais e municípios de grande porte. Portanto, pode-se afirmar que São Paulo não se integrou ao SUS durante a maior parte da década de 1990; somente a partir de 2001 evidenciou-se a retomada do sistema nessa cidade.

A implantação tardia do SUS, por si só, já representa um desafio, que é ainda maior em decorrência das características do Município de São Paulo, que tem uma população residente estimada em 10,88 milhões de habitantes ${ }^{1}$, é sede da maior região metropolitana do país. Além disso, é uma das principais referências nacionais para saúde por causa da grande quantidade e complexidade de serviços e estabelecimentos de saúde instalada em seu território.

É importante ressaltar, também, que, considerando-se os gastos realizados pelas três esferas de governo (federal, estadual e municipal), o Município de São Paulo, entre os entes federados do país, detém o terceiro maior gasto público em ações, serviços e estabelecimentos de saúde, atrás apenas dos gastos totais do Ministério da Saúde e do Estado de São Paulo (Departamento de Informática do SUS. Sistema de Informações sobre Orçamentos Públicos em Saúde. http://siops.datasus.gov.br, acessado em 25/Abr/2008).

Para uma melhor compreensão do contexto local e do que ocorreu na saúde nesse município nos últimos anos, é necessário resgatar o processo histórico da gestão municipal, em particular, a partir do período 1989-1992, no qual se identifica a 
primeira tentativa de implantar uma política de saúde alinhada ao SUS. Essa política foi implementada concomitantemente ao processo de institucionalização do próprio SUS no país. Vale lembrar que a legislação que regulamentou o SUS - Leis Federais $\mathrm{n}^{\mathrm{o}} 8.080^{2}$ e $\mathrm{n}^{\mathrm{o}} 8.142^{3}$ - foi promulgada entre setembro e dezembro de 1990 . Foi nesse contexto, com uma base de sustentação jurídico-legal ainda frágil e em uma situação política complexa e desfavorável na sua relação com as esferas federal e estadual de governo, que a gestão municipal de São Paulo implantou uma política de saúde orientada pelos princípios e diretrizes constitucionais do SUS.

Até 1988, a organização político-administrativa da Secretaria Municipal de Saúde (SMS-SP) era centrada em duas estruturas departamentais: o Departamento de Saúde da Comunidade, que coordenava postos de atendimento médico; e a Superintendência Médico-Hospitalar de Urgência, que coordenava prontos-socorros e hospitais. A gestão 1989-1992 promoveu uma reorganização da SMS-SP, descentralizando suas atribuições político-administrativas em dez Administrações Regionais de Saúde e 32 Distritos de Saúde, que, em virtude da concomitante descentralização orçamentária e financeira, ganharam relativa autonomia e agilidade para gastos, incluindo-se contratação de pessoal ${ }^{4,5,6}$. Ao final dessa gestão, todos os estabelecimentos de saúde do município - hospitais, prontos-socorros, ambulatórios de especialidades e UBS (unidades básicas de saúde) - encontravam-se subordinados a e coordenados pelos Distritos de Saúde de sua região; estes, por serem unidades orçamentárias ${ }^{4}$, tinham inclusive mais autonomia.

Concomitantemente ao rearranjo de sua estrutura organizacional, a direção da SMSSP buscou abrir um processo de negociação com a Secretaria de Estado da Saúde de São Paulo (SES-SP), visando a iniciar a municipalização das UBS estaduais e a 
construção de um comando único da rede básica no município. Contudo, devido a contradições e conflitos político-partidários, essa política ficou limitada à transferência para o município de cerca de 50 UBS estaduais ${ }^{4}$, que representavam aproximadamente $18 \%$ das que estavam em atividade no Município de São Paulo.

No período 1993-1996, com uma forte orientação gerencialista ${ }^{7}$, foi implementada uma nova política de gestão pública justificada pelo argumento da necessidade de aumentar a eficiência da máquina pública. Um novo modelo assistencial e de gestão da saúde - o Plano de Atendimento à Saúde - foi implantado no último ano dessa gestão ${ }^{4,8}$, após três anos de conflitos e embates políticos no legislativo que contribuíram para postergar sua institucionalização. Nesse período, a maioria dos serviços e estabelecimentos de saúde, de caráter assistencial, vinculados a SMS-SP 16 hospitais, 16 prontos-socorros, 14 ambulatórios de especialidades e 99 UBS -, foi cedida para cooperativas privadas de profissionais de saúde, organizadas exclusivamente para esse fim, à exceção das 50 UBS municipalizadas ${ }^{4,8,9}$.

Submetida ao Plano de Atendimento à Saúde, a assistência à saúde no Município de São Paulo foi organizada em 14 módulos assistenciais regionais. Cada módulo coordenava de 7 a 14 UBS e, pelo menos, um hospital e um pronto-socorro, os quais funcionavam como referência regional. O Plano foi financiado com recursos da SMS-SP, alocados a cada módulo por mecanismo de capitação: inicialmente, por população coberta estimada, que, depois, deveria evoluir para população efetivamente cadastrada, com um valor fixo per capita por ano ${ }^{4,8,9}$. É importante ressaltar que, após denúncia e pressão do Conselho Municipal de Saúde junto ao Conselho Nacional de Saúde, o Ministério da Saúde suspendeu seus repasses financeiros para o município. A partir desse momento, os recursos que financiaram o 
Plano de Atendimento à Saúde eram oriundos quase exclusivamente da receita do próprio município.

Esse modelo assistencial e de gestão, além de não respeitar princípios constitucionais do SUS, aprofundou contradições e conflitos entre a política do Município de São Paulo e as políticas estadual e nacional de saúde. Nesse contexto, a gestão que iniciou em 2001 assumiu o compromisso político de extinguir o Plano de Atendimento à Saúde e reconstruir o SUS no Município de São Paulo.

Neste artigo, buscou-se explorar a continuidade das políticas implementadas, por duas gestões municipais de distintas frentes partidárias. Deve-se considerar que, em democracias representativas, com a possibilidade de alternância de partidos políticos nos governos, pode haver mudanças de políticas ou de prioridades.

Assim, os objetivos centrais deste estudo foram identificar e avaliar as políticas de saúde priorizadas pelo Município de São Paulo, no processo de reconstrução do SUS, que tiveram sustentação política nas gestões posteriores a 2001.

\section{Métodos}

Este estudo abarcou duas administrações do Município de São Paulo, no período 2001 a 2008. A primeira desencadeou o processo de reconstrução do SUS nesse município; a segunda manteve o município no SUS, mas apresentou propostas de mudanças na gestão da política municipal de saúde.

Optou-se pela estratégia metodológica do estudo de caso, que é caracterizado como uma investigação empírica sobre um fenômeno contemporâneo complexo, em seu contexto, especialmente quando os limites entre o fenômeno e o contexto não estão

claramente definidos ${ }^{10}$. Em face dessas características, essa estratégia tem sido 
utilizada em pesquisas sobre política e administração públicas, particularmente, no setor saúde ${ }^{10,11}$.

O trabalho de campo foi desenvolvido entre julho de 2005 e junho de 2008, tendo contemplado a identificação e a coleta de dados por meio de distintas fontes e estratégias: entrevistas com informantes privilegiados, documentos de gestão e observação participante. Nesse percurso, foram enfrentadas dificuldades para o acesso a alguns documentos internos de gestão e para a realização de entrevistas com gestores e técnicos em situação de gestão. A obtenção de informações da administração 2005-2008 foi mediada por interlocutor da assessoria do gabinete do secretário, estrutura de nível central da SMS-SP.

O material analisado constava de documentos oficiais publicados ou disponibilizados em meios oficiais - diário oficial do município e sítio da SMS-SP na rede web - e aqueles publicados, de forma autoral, por atores institucionais da gestão, ou ainda aqueles não publicados fornecidos por técnicos e assessores da SMS-SP.

Foram realizadas entrevistas semi-estruturadas, utilizando-se para tanto um roteiro básico com pontos considerados centrais, em torno dos quais os autores exploraram questões mais relevantes, o que permitiu detalhar temas de interesse. Essas entrevistas, realizadas no período entre março de 2006 e julho de 2007, foram conduzidas por, pelo menos, dois dos autores; um ex-gestor não foi entrevistado pelo fato de existirem informações impressas e autorais de seu período de gestão. Todas foram gravadas e, posteriormente, transcritas por um assistente de pesquisa. A duração variou entre 60 até cerca de 100 minutos.

A observação participante foi desenvolvida em reuniões do Conselho Municipal de Saúde de São Paulo, em Conferências Municipais de Saúde e em encontros com 
gestores e técnicos da gestão do período estudado. Essa atividade foi complementada pelo registro sistemático das informações.

Com o apoio dessas técnicas, buscou-se compreender as relações entre "intenções", construídas e expressas na formulação das políticas, e "ações", que são expressão da vida real e estão presentes na fase de implementação dessas políticas ${ }^{11}$.

Para tanto, duas categorias analíticas centrais foram consideradas: política de saúde e gestão em saúde. O conceito de política de saúde adotado abrange questões relativas tanto ao poder propriamente dito, envolvendo processos eminentemente contraditórios e conflituosos, quanto ao estabelecimento de diretrizes, planos e programas de saúde. O conceito de gestão em saúde contempla questões de criação e de utilização de meios para concretizar os princípios de organização da política ${ }^{12}$.

A identificação e a eleição das políticas priorizadas pela SMS-SP, no período estudado, foram realizadas por meio de recortes temáticos sobre o conteúdo dos dados coletados e com base em três critérios centrais: destaque no discurso de gestores ou em documentos de gestão, continuidade nas duas gestões analisadas e concordância de escolha entre os autores.

O projeto da pesquisa, que gerou os dados analisados neste artigo, foi aprovado pelos Comitês de Ética em Pesquisa da Faculdade de Saúde Pública, Universidade de São Paulo (FSP/USP) e da SMS-SP (Processo CEP/SMS Nº 0084.0.162.207-05), com base na Resolução 196/96 do Conselho Nacional de Saúde.

\section{Resultados}

No período 2001-2004, a SMS-SP teve dois secretários titulares, cada um com período médio de gestão de 24 meses. No período 2005-2008, quatro secretários 
alternaram-se na direção da SMS-SP, com períodos de gestão que variaram entre cinco e 17 meses. Considerando-se todo o período estudado, a duração média dos gestores da saúde foi de aproximadamente 13 meses, variando de cinco até 24 meses. O perfil profissional e uma breve trajetória da vida pública desses gestores da saúde municipal encontram-se relacionados na Tabela 1.

Tabela 1. Perfil profissional e trajetória pública dos titulares da Secretaria Municipal de Saúde. São Paulo (SP): 2001 a 2008.

\begin{tabular}{|c|c|c|}
\hline Gestor & Perfil profissional & Trajetória pública \\
\hline $\mathbf{A}$ & $\begin{array}{l}\text { Médico, com especialização em } \\
\text { Saúde Pública } \\
\text { Médico sanitarista (SES-SP) }\end{array}$ & $\begin{array}{l}\text { Deputado Estadual (SP) (1983-87) } \\
\text { Deputado Federal (SP) (1988-2003) } \\
\text { Secretário - SMS de município de grande porte } \\
\quad \text { (SP) (1989-90) } \\
\text { Secretário - SMS-SP (2001-02) }\end{array}$ \\
\hline $\mathbf{B}$ & $\begin{array}{l}\text { Médico, com especialização e } \\
\text { mestrado em Administração } \\
\text { Hospitalar } \\
\text { Professor (universidade pública) } \\
\text { e administrador hospitalar } \\
\text { (hospitais público e privados) }\end{array}$ & $\begin{array}{l}\text { Chefe de Gabinete - SMS de município de } \\
\text { grande porte (SP) (1993-94) } \\
\text { Diretor Superintendente de Hospital de Clínicas } \\
\text { em município de grande porte (SP) (1997-98) } \\
\text { Diretor-Presidente de Agência Nacional da área } \\
\quad \text { de Regulação da Saúde (1999-2002) } \\
\text { Secretário - SMS-SP (2003-04) }\end{array}$ \\
\hline $\mathbf{C}$ & $\begin{array}{l}\text { Médico, com especialização, } \\
\text { mestrado e doutorado em } \\
\text { Oftalmologia } \\
\text { Médico e administrador } \\
\text { hospitalar (hospital privado) e } \\
\text { professor (universidade pública) }\end{array}$ & $\begin{array}{l}\text { Presidente de Sociedade Beneficiente } \\
\text { mantenedora de Hospital Privado (2000-atual) } \\
\text { Secretário - SMS-SP (2005) }\end{array}$ \\
\hline $\mathbf{D}$ & $\begin{array}{l}\text { Médica, com especialização e } \\
\text { doutorado em Pediatria } \\
\text { Professor (universidade privada) } \\
\text { e médico (SES-SP) }\end{array}$ & $\begin{array}{l}\text { Diretor de Faculdade de Medicina (1995-atual) } \\
\text { Diretor-Superintendente de Hospital Geral de } \\
\quad \text { tipo OSS da SES-SP (1998-atual) } \\
\text { Secretário - SMS-SP (2005-06) }\end{array}$ \\
\hline $\mathbf{E}$ & $\begin{array}{l}\text { Médica, com especialização em } \\
\text { Direito Sanitário } \\
\text { Médico (MS) }\end{array}$ & $\begin{array}{l}\text { Diretor de Departamento Nacional do MS da área } \\
\text { de Avaliação e Controle do SUS (1999-2002) } \\
\text { Coordenador de Programa de Atenção Específico } \\
\text { da SMS de município de grande porte (SP) } \\
\text { (2005-06) } \\
\text { Secretário - SMS-SP (2006-07) }\end{array}$ \\
\hline $\mathbf{F}$ & $\begin{array}{l}\text { Administrador de empresas } \\
\text { Administrador (empresa pública } \\
\text { da área de Energia Elétrica) }\end{array}$ & $\begin{array}{l}\text { Secretário - Municipal de Recursos Humanos e } \\
\text { da Administração de município de grande } \\
\text { porte (SP) (1993-99) } \\
\text { Diretor-Presidente de Agência Nacional da área } \\
\text { de Regulação da Saúde (1999-2003) } \\
\text { Secretário - Municipal da Gestão Pública de } \\
\text { município de grande porte (SP) (2005-07) } \\
\text { Secretário - SMS-SP (2007-08) }\end{array}$ \\
\hline
\end{tabular}


Com base nos critérios citados anteriormente, foram identificadas as principais políticas priorizadas pelas duas gestões municipais estudadas: (a) reincorporação do Município de São Paulo ao SUS; (b) reorganização administrativa da SMS-SP; e (c) expansão do Programa de Saúde da Família (PSF) no município (Tabela 2).

Tabela 2. Políticas identificadas como prioritárias e seus eixos principais. São Paulo (SP): 2001 a 2008.

\begin{tabular}{|c|c|}
\hline Política (período) & Eixo \\
\hline $\begin{array}{l}\text { Reincorporação do MSP ao SUS } \\
(2001-2008)\end{array}$ & $\begin{array}{l}\text { - reorganização e manutenção das instâncias de } \\
\text { participação e controle sociais } \\
\text { - extinção do PAS } \\
\text { - municipalização de } 200 \text { UBSs estaduais: } \\
141 \text { (2001); } 59 \text { com PSF/Qualis (2002) } \\
\text { - habilitação do MSP: na GPAB (fev/2001); na } \\
\text { GPSMS (jun/2003) }\end{array}$ \\
\hline $\begin{array}{l}\text { 1 }^{\text {a }} \text { Reorganização administrativa } \\
\text { da SMS-SP } \\
(2001-2004)\end{array}$ & $\begin{array}{l}\text { - distritalização dos serviços ambulatoriais: } \\
\text { criação de } 41 \text { DSs (2001); redimensionados } \\
\text { para } 31 \text { Coordenadorias de Saúde, vinculadas } \\
\text { às Subprefeituras (2002) } \\
\text { - autarquização dos hospitais e PSs municipais: } \\
\text { criação de } 5 \text { Autarquias Hospitalares }\end{array}$ \\
\hline $\begin{array}{l}2^{\text {a }} \text { Reorganização administrativa } \\
\text { da SMS-SP } \\
(2005-2008)\end{array}$ & $\begin{array}{l}\text { - extinção das } 31 \text { Coordenadorias de Saúde } \\
\text { - criação de } 5 \text { Coordenadorias Regionais de } \\
\text { Saúde (CRSs) } \\
\text { - criação de } 24 \text { Supervisões Técnicas de } \\
\text { Saúde (STSs), subordinados a } 5 \text { CRSs } \\
\text { - manutenção das } 5 \text { Autarquias Hospitalares; } \\
\text { reorganizadas funcionalmente em } 2 \text { (uma } \\
\text { assistencial; outra administrativa) (2007-08) }\end{array}$ \\
\hline $\begin{array}{l}\text { Expansão do PSF } \\
(2001-2008)\end{array}$ & $\begin{array}{l}\text { - } 159 \text { equipes implantadas do PSF/Qualis } \\
\text { (dez/2000) expandidas para } 850 \text { equipes do } \\
\text { PSF (jun/2008) } \\
\text { - parceria da SMS-SP com entidades privadas: } \\
\text { gestão de pessoal do PSF (seleção, contratação } \\
\text { e capacitação) e contratação de serviços de } \\
\text { apoio diagnóstico (2001); ampliação para a } \\
\text { gerência de estabelecimentos (hospitalares e } \\
\text { ambulatoriais) (2006-07) }\end{array}$ \\
\hline
\end{tabular}




\section{Reincorporação do Município de São Paulo ao SUS}

Esta pode ser caracterizada como política prioritária da gestão municipal, iniciada em 2001, que foi implementada por meio de três eixos principais: a reorganização das instâncias de participação e controle sociais, a extinção do antigo Plano de Atendimento à Saúde e a municipalização da rede básica estadual.

A participação social foi implementada, desde 2001, por meio da reinstitucionalização das instâncias formais de controle social do SUS no município: Conselho Municipal de Saúde, Conferências Municipais de Saúde e Conselhos Gestores de Unidades. Esse processo foi destacado pelo gestor do período como:

"A democratização partiu dos sobreviventes/resistentes do Conselho Municipal de Saúde [...] que haviam sido esmagados nos anos anteriores. [...] De trinta conselheiros fomos para mais de 4000, [...] com dezenas de cursos de formação sobre o SUS” ${ }^{13}$ (p.27).

As duas gestões municipais mantiveram essa política e suas instâncias formais. No período, foram realizadas quatro Conferências Municipais de Saúde, duas por cada gestão, e reuniões do Conselho Municipal de Saúde com relativa regularidade. Não sem conflitos, como a crise instalada com o questionamento da SMS-SP sobre a representatividade de parte do segmento dos usuários, que quebrou a institucionalidade do Conselho Municipal de Saúde por aproximadamente quatro meses, no início de 2008. Essa crise só foi superada após a intermediação do Ministério Público Estadual ${ }^{14}$.

A extinção do Plano de Atendimento à Saúde, que foi concluída em junho de 2001, e os esforços despendidos nesse processo foram caracterizados nos seguintes termos:

"No ano de 2001, primeiro ano de governo, a capital paulista passa a integrar-se, finalmente, junto a tantos outros municípios brasileiros no esforço 
nacional de construção do Sistema Único de Saúde. Tarefa árdua, desafiadora e prioridade n ${ }^{o} 1$ na Área da Saúde no Governo da Reconstrução” (Relatório de Gestão SMS-SP 2002).

No mesmo Relatório, a situação e dificuldades encontradas, bem como a transição implementada, foram caracterizadas pelo gestor municipal da época com as seguintes palavras:

“A SMS encontrava-se fraturada em três segmentos [...]: 17 mil trabalhadores do Plano de Atendimento à Saúde divididos entre 12 mil contratados em situação trabalhista irregular perante a lei e 5 mil funcionários estáveis da Prefeitura; 13 mil trabalhadores da saúde que restaram [...]; 10 mil trabalhadores da saúde 'exilados' da Secretaria Municipal de Saúde [...] nos diversos cantos da máquina administrativa” (Relatório de Gestão SMS-SP 2002).

Nesse contexto e associado ao compromisso de extinguir o Plano de Atendimento à Saúde, impôs-se o desafio de regularizar a situação funcional desse contingente de pessoal, o que exigiu "uma megamovimentação de pessoal feita com o máximo de prudência e tolerância. [...] Uma transição respeitando a lei municipal e os prazos dos contratos das cooperativas" ${ }^{13}$ (p.12).

O reconhecimento do Município de São Paulo como gestor único da atenção básica foi outro eixo dessa política, que imprimiu marca e identidade com o SUS, e foi expresso pelo rápido processo de negociação política com a SES-SP e o MS, habilitando o município na condição de Gestão Plena da Atenção Básica, já em fevereiro de $2001^{15}$.

Como desdobramento desse processo, foi implementada a municipalização da rede básica estadual, em dois momentos distintos: no período entre junho e dezembro de 2001, foram municipalizados 141 UBS e 12 ambulatórios de saúde mental; em abril 
de 2002, foram municipalizadas outras 59 UBS, com cerca de 200 equipes do PSF/Qualis ${ }^{15}$. Com base nesse quadro, o gestor da época avaliou que:

“O diálogo rompido foi retomado e [...] todas as unidades básicas estaduais sediadas na capital (200) estão funcionando articuladas com as unidades básicas municipais (150) sob a gerência unificada de SMS” ${ }^{13}$ (p.13).

Após a municipalização da rede básica estadual, essa gestão pleiteou a habilitação do município na condição de gestão plena do sistema municipal de saúde.

“Em novembro de 2002, a Secretaria deu entrada no pedido de gestão plena. Estão em andamento as negociações do repasse para a nossa gerência dos quarenta hospitais estaduais e outros tantos serviços especializados estaduais sediados na capital e também o acompanhamento dos serviços de saúde privados, filantrópicos e lucrativos, conveniados com o SUS na cidade" 13 (p.13).

No entanto, a habilitação do Município de São Paulo na condição de gestão plena do sistema municipal de saúde só foi viabilizada em $2003{ }^{16}$, após a mudança do gestor da saúde municipal. Em que pese a complexidade da rede pública estadual de saúde e dos prestadores privados no município, em virtude de limitações orçamentárias e financeiras, a SMS-SP pactuou uma gestão plena do sistema municipal de saúde que teve precária participação financeira da SES-SP, como se percebe no relato do gestor do período:

"Nós entramos na batalha da municipalização [...], de certa maneira, sozinhos. O Estado, num primeiro momento topou entrar, mas não queria rediscutir nenhuma distribuição de recursos. [...] Falaram: 'Olha, vocês chegaram por último. E quem chega por último (na festa), come o que tem'. [...] 'O que sobrou da Programação Pactuada Integrada do Estado é isso [...]'. O secretário executivo do Ministério conseguiu minimizar esse impasse [...] retirou recursos de outros locais do país e alocou em São Paulo" (gestor B). 
Nesse sentido, o mesmo gestor apresentou a fragilidade da gestão plena assumida, nos seguintes termos:

"Como é que dá pra discutir a questão da integralidade, se uma parte da rede ambulatorial especializada não tem nada a ver com a prefeitura? [...] Se meu acesso hospitalar não tem nenhum nexo com o processo de atenção à saúde? Quero dizer, se a porta de entrada à dimensão hospitalar é o prontosocorro?" (gestor B).

Uma variável conjuntural importante, identificada no contexto político da época, foi que "Na hora que o movimento da eleição começou, azedou tudo! [...] A partir de abril/maio de 2004, essas coisas foram congeladas e não avançamos mais, praticamente, nada” (gestor B).

Com base nesses depoimentos, pode-se observar que o Município de São Paulo teve que assumir uma gestão plena do sistema municipal de saúde sem lograr qualquer avanço na gestão ou municipalização dos serviços de saúde de média e alta complexidades estaduais ou outros prestadores sob gestão estadual.

\section{$\underline{\text { Reorganização administrativa da SMS-SP }}$}

Cada gestão analisada implementou uma reestruturação administrativa na Secretaria, visando à adequação da estrutura existente para a implementação dos projetos prioritários de governo.

A primeira reorganização da SMS-SP teve início em 2001 e sua implantação compreendeu dois eixos principais: a descentralização administrativa da rede ambulatorial; e uma nova conformação da rede de hospitais e de prontos-socorros municipais.

A descentralização da gestão da rede ambulatorial foi implementada por meio da criação de 41 Distritos de Saúde, por ato do secretário, em janeiro de 2001. A gestão 
municipal justificou a necessidade desse processo, caracterizado na época como “distritalização", por avaliar que:

“Não é possível uma operação de municipalização [...] mantendo as atuais estruturas dos cinco núcleos em que se divide a Administração Estadual aqui na capital e as dez Administrações Regionais de Saúde [...], levando-se em conta os limites dos 96 Distritos Administrativos da cidade [...] para compatibilizar os nossos 41 Distritos nos limites das futuras prefeituras regionais" 17 (p.10-1).

Em 2002, como desdobramento da descentralização político-administrativo da prefeitura de São Paulo com a criação de 31 Subprefeituras, os 41 Distritos de Saúde iniciais foram reorganizados em 31 Coordenadorias de Saúde e vinculados às novas Subprefeituras ${ }^{18,19}$. As competências dessas instâncias eram limitadas à coordenação das UBS e dos ambulatórios de especialidades.

Em 2004, na tentativa de superar críticas sobre uma potencial duplicidade de comando entre o gestor municipal da saúde (SMS) e o gestor regional do município (Subprefeitura), foi promulgado um decreto específico, determinando que " $O$ Secretário Municipal da Saúde é o dirigente único do Sistema Único de Saúde no Município de São Paulo, cabendo-lhe manter a unicidade conceitual e política do Sistema” ${ }^{19}$ (p.1).

Paralelamente à distritalização, foram criadas cinco autarquias hospitalares ${ }^{21}$. Uma das justificativas para tanto, foi a situação encontrada em 2001, refletida nas dificuldades relatadas por um informante privilegiado da área de gestão hospitalar, no trecho que segue: "Com a extinção do Plano de Atendimento à Saúde e a demissão do pessoal contratado irregularmente, o hospital X não tinha o pessoal mínimo necessário para mantê-lo em funcionamento”. Já o gestor municipal do 
período avaliou essa reforma da SMS-SP como o resultado da "coragem de inventar novas formas ou reinventar velhas formas adaptando-as a nossa realidade", caracterizando-a como uma "Modernização da Gestão" 13 (p.13-14).

A segunda reorganização administrativa da SMS-SP foi implementada como uma das primeiras medidas do novo governo municipal eleito, iniciado em 2005. Com uma justificativa racionalizadora para a mudança, o gestor do período relatou sua avaliação sobre a estrutura administrativa da saúde encontrada no município:

“Na Secretaria, [...] secretário da saúde lidera um grupo de cinco autarquias. Essas autarquias têm um grupo de 15 hospitais e alguns prontos-socorros. [...] Cada subprefeitura tinha um coordenador de saúde que, ao invés de se reportar ao secretário da saúde, se reportava ao subprefeito. [...] Sob o sentido da racionalização de recursos, é absolutamente fora de propósito! [...] Não poderia existir um coordenador de saúde que trabalha longe do secretário da saúde. E, pior, um sistema ambulatorial que não conversa com o sistema hospitalar!" (gestor C).

E, em face da situação encontrada, o mesmo gestor justifica as medidas adotadas:

"Vamos acabar com essa história de ter um subsecretário para cada região. [...] Daí, a razão de acabarmos com as coordenadorias e criar cinco coordenadorias regionais. [...] Eram cinco autarquias hospitalares. [...] Vou acabar com essa história de um ambulatório separado do hospital e vou criar essa integração!” (gestor C).

Dessa forma, sem fazer uma reforma administrativa formal, a nova gestão nomeou apenas cinco coordenadores de saúde, em uma estrutura que previa 31 cargos de coordenadores. Na prática, foi implementada uma reforma funcional, ampliando-se a responsabilidade de cada coordenador para um território abrangendo de quatro até sete subprefeituras ${ }^{22}$. Em outubro de 2005 , um decreto transferiu as coordenadorias das subprefeituras para a SMS-SP, oficializando as cinco Coordenadorias Regionais 
de Saúde, e criando 24 Supervisões Técnicas de Saúde subordinadas às primeiras ${ }^{23}$. Contudo, essa gestão manteve as competências dessas instâncias limitadas à coordenação dos serviços ambulatoriais.

Apesar do discurso manifesto, as autarquias hospitalares foram mantidas. Em março de 2006, outro decreto alterou sua denominação e instituiu a integração formal das cinco Coordenadorias Regionais de Saúde com a Rede Hospitalar Municipal, de acordo com sua localização geográfica ${ }^{24}$. Por fim, em 2008, essas instâncias foram reorganizadas, funcionalmente, em apenas duas autarquias: uma de caráter administrativo e outra de coordenação técnica dos hospitais municipais.

\section{Expansão do PSF no município}

Em dezembro de 2000, o Município de São Paulo tinha 159 equipes de saúde da família cadastradas e uma cobertura populacional estimada em $5,5 \%{ }^{25}$. Todas estavam sob gestão da SES-SP e eram denominadas PSF/Qualis. A partir de 2001, com a municipalização das UBS estaduais, a expansão do PSF foi assumida pela gestão como prioridade e principal estratégia de mudança do modelo assistencial do SUS na cidade (Figura 1). A relevância dessa política pode ser observada no discurso do gestor do período:

“Nossa opção para o modelo de atenção foi apostar alto no potencial revolucionário do Programa de Saúde da Família. [...] Adesão dos usuários, sua capacidade de humanizar as relações profissional de saúde/cidadão usuário, sua força racionalizadora da rede hospitalar e especializada com a rede básica, mostraram o acerto de nossa escolha política e orçamentária" 13 (p.28). 
Figura 1. Evolução trimestral das equipes de saúde da família (ESF) implantadas. São Paulo (SP): 2000 a 2008.

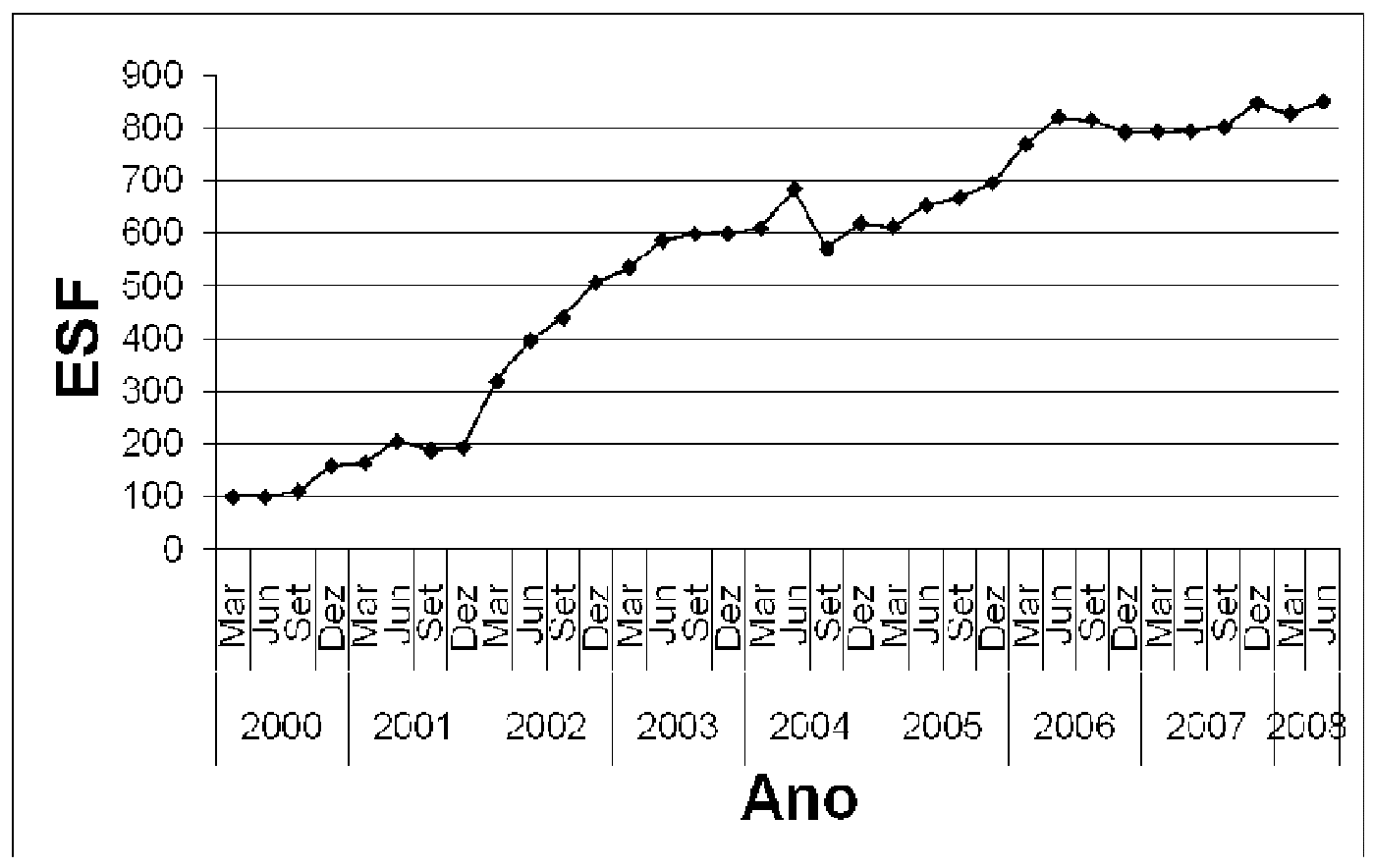

Fonte: MS.DAB ${ }^{24}$

A prioridade dada a essa política por esse gestor pode ser identificada no relato de um informante privilegiado, do gabinete da SMS-SP, que o caracterizou como um secretário que "transpirava PSF por todos os poros! Era PSF, PSF... Tudo era $P S F !$ ”. O caráter e a importância dados ao PSF por essa gestão foram documentados da seguinte forma:

“A SMS terá sua rede básica gradativamente transformada pela estratégia da Saúde da Família nos próximos quatro anos. [...] É diretriz da SMS implantar a estratégia da Saúde da Família nas UBS, com meta de cobertura de $60 \%$ da população" 26 .

A institucionalização desse programa se deu por meio da Portaria $n^{o} 3.822^{27}$, segundo a qual a meta de cobertura especificada foi a implantação de 1.749 equipes até 2004. Apesar dos esforços para implementar essa política, a meta estabelecida 
mostrou-se difícil de ser atingida. Na prática, o Ministério da Saúde registrava um total de 619 equipes de saúde da família implantadas no Município de São Paulo, em dezembro de 2004, e estimava sua cobertura populacional em $20,0 \%{ }^{25}$.

A gestão municipal do período 2005-2008 continuou expandindo o PSF, atingindo um total de 850 equipes de saúde da família implantadas até junho de 2008, o que representava $26,6 \%$ de cobertura populacional ${ }^{25}$. Pode-se observar que o ritmo de implantação do PSF no município não foi regular, apresentando variações entre as duas gestões estudadas (Figura 1).

Uma das estratégias utilizadas para a expansão do PSF, no Município de São Paulo foi instalar as equipes de saúde da família nas UBS municipais ou municipalizadas, transformando esses estabelecimentos, seja em unidades de saúde da família, seja em unidades “mistas”. Nestas, as equipes de saúde da família passaram a conviver com equipes ditas "tradicionais", compostas por médicos pediatras, ginecologistas e clínicos; algumas com médicos sanitaristas, psiquiatras, psicólogos, fonoaudiólogos, fisioterapeutas. Contudo, essa estratégia não conseguiu expandir a implantação do programa e ampliar o acesso em áreas descobertas de serviços, como se pode deduzir do comentário de um dos gestores do período:

“A instalação dos PSF na cidade, apesar de ter sido concentrada na periferia, tem três equipes aqui, tem uma lá na Vila Madalena, tem uma do lado da Escola Paulista de Medicina. Enfim, houve uma expansão, não totalmente crítica do PSF na cidade. [...] Não conseguiu saturar áreas porque abriu tantas frentes, no início. Isso transformou muitas regiões da cidade num ‘queijo suiço'”' (gestor B).

Outra estratégia adotada pelas duas gestões municipais para a implementação dessa política foi a manutenção das mesmas parcerias com entidades privadas, que 
intermediaram a gestão de pessoal do programa, tanto para seleção e contratação, quanto para sua capacitação. Assim, a SMS-SP manteve as quatro entidades parceiras da SES-SP, para a implantação do PSF/Qualis, e ampliou esse número para 12, ainda em $2001^{28}$. Todas foram mantidas pela gestão 2005-2008, exceto uma que atingiu situação falimentar em 2007 e foi substituída. Neste último período, a coordenação das equipes do PSF deixou de ser atribuição de pessoal de carreira da SMS-SP e foi transferida para as entidades parceiras.

\section{Discussão}

Desde 2001, o Município de São Paulo vem implementando políticas de saúde que respeitam os princípios constitucionais da universalidade, particularmente de acesso à atenção básica, e da participação e controle social do SUS. Em relação à integralidade, na sua dimensão sistêmica, em que pese o fato de o município ter uma relevante quantidade de serviços e equipamentos instalados em seu território, é fundamental que sejam superadas as precárias condições nas quais o município foi habilitado como gestão plena do sistema municipal de saúde, para que possa assumir a gestão de todas as ações e serviços de fato.

Uma das variáveis intervenientes relaciona-se com a política municipal de saúde das gestões 1993-2000 que criou o Plano de Atendimento à Saúde como um sistema assistencial paralelo que não respeitava os princípios do SUS. Concomitante, foi implementada uma progressiva desestruturação da SMS-SP, em particular dos antigos distritos de saúde. Nesse sentido, a mera extinção do Plano de Atendimento à Saúde não foi suficiente para resgatar a estrutura organizacional anterior à sua implantação. 
Em relação ao pessoal técnico da SMS-SP, não houve o retorno ou reposição daqueles que haviam sido absorvidos por outras secretarias, principalmente em áreas como a jurídico-legal e financeiro-contábil. O depoimento de um dos gestores do período corrobora essa análise:

"A melhor estrutura gerencial das três esferas de governo era a estrutura do município. Na saúde, ela foi destruída. Quem foi embora, com o Plano de Atendimento à Saúde, voltou quando era da área fim. Os da área meio nunca mais voltaram. [...] A burocracia não voltou mais. [...] A secretaria, até hoje, não se recuperou. [...] Aquele departamento de apoio técnico, [...] pode ser dito que era um relógio. Barulhento, atrasava um pouco, mas era um relógio" (gestor B).

Não foi possível identificar, nas duas gestões estudadas, qualquer movimento a fim de resgatar as atribuições e competências dos distritos de saúde organizados na gestão 1989-1992. Observou-se que o processo de reestruturação da SMS-SP não avançou no sentido de superar os entraves existentes para uma efetiva articulação entre distintos serviços públicos de saúde instalados no município. Por um lado, foram estruturadas instâncias administrativas locorregionais, com atribuições e competências limitadas à coordenação e controle das atividades dos estabelecimentos ambulatoriais sob gestão municipal. Por outro lado, a reorganização dos hospitais e prontos-socorros municipais foi implementada por meio da criação de outra estrutura administrativa. E, ainda, foram mantidos diversos serviços estaduais sob gestão, de fato, da SES-SP.

Embora as duas gestões estudadas tenham priorizado e implementado políticas de reestruturação da SMS-SP, o SUS no município ficou fragmentado em três segmentos de estabelecimentos público-estatais, com estruturas de coordenação próprias: (a) os estabelecimentos ambulatoriais sob gestão municipal: ambulatórios 
de especialidades, UBS e serviços de pronto atendimento tipo AMA (Atendimento Médico Ambulatorial); (b) os estabelecimentos hospitalares e de urgência e emergência sob gestão municipal: hospitais e prontos-socorros; e (c) os estabelecimentos sob gestão estadual: ambulatórios e hospitais de especialidades. Na prática, constatou-se a coexistência de três subsistemas da saúde paralelos, o que representa um importante obstáculo para uma melhor articulação entre serviços de distintas densidades tecnológicas. Nesse contexto, fica comprometida a efetiva implementação da integralidade da atenção no SUS, no Município de São Paulo. É importante considerar, ainda, que outro fator que fragiliza essa integralidade está relacionado com a tradição, o papel e o poder das instituições presentes nessa arena política, particularmente dos hospitais, por sua relação com o poder médico, por sua relativa autonomia funcional e pela possibilidade de constituir clientelas próprias ${ }^{29}$. Uma variável que deve ser considerada na análise das reorganizações implementadas está relacionada com o perfil profissional e a trajetória pública dos gestores. No período estudado, constatou-se que, dos seis secretários que se alternaram na direção da SMS-SP, apenas três tinham formação profissional na área da saúde pública/coletiva e/ou trajetória vinculada ao processo de construção do SUS no país. Esse fato impõe a necessidade de se aprofundar a discussão sobre a relevância desta variável, na medida em que o conhecimento e o entendimento dos gestores sobre o SUS, enquanto política pública, podem qualificar e fortalecer sua capacidade de governo, conforme identificado por outros autores ${ }^{30}$.

Outra constatação importante deste estudo relaciona-se com a alta rotatividade observada entre os gestores da saúde. Embora possa ter alguma particularidade, essa problemática parece não ser específica das capitais. Assim, avaliamos que essa 
rotatividade compromete a sustentação das políticas de saúde que fortaleçam o SUS, mesmo em contextos favoráveis com gestores de saúde qualificados e com alta capacidade de governo.

O PSF foi identificado como uma das políticas priorizadas e que teve continuidade nas duas gestões, inclusive, com a manutenção da mesma denominação “genérica”. É importante considerar que essa sustentação política pode estar relacionada com o fato de esse programa ser uma prioridade do Ministério da Saúde, com estímulo financeiro vinculado, e, também, por não ter se constituído como uma marca política da primeira gestão municipal. A indução dessa política pelo Ministério da Saúde, por meio de estímulos financeiros aos municípios, configura uma forma de (re)modelar a atenção básica com uma única estratégia em todo o país e pode ser caracterizada como um tipo de isomorfismo institucional ${ }^{31}$.

Apesar dos esforços despendidos, a SMS-SP conseguiu atingir 48,5\% da meta proposta, implantando 850 equipes de saúde da família com uma cobertura populacional de 26,6\%. Ainda assim, o programa do Município de São Paulo é o maior do país. Para se ter a dimensão das dificuldades em atingir a meta proposta, deve-se considerar que mesmo capitais que alcançaram altos níveis de cobertura populacional, como Belo Horizonte, Minas Gerais, com 68,6\% de cobertura, tem um total de 477 equipes de saúde da família implantadas. Por outro lado, o PSF no Município de Fortaleza, Ceará, que é a capital do estado que iniciou a implantação desse programa no país, tem uma cobertura de apenas 25,7\%, com 180 equipes de saúde da família ${ }^{25}$, refletindo em boa medida as dificuldades operacionais de implantação do programa em grandes municípios. 
A estratégia de (re)modelagem da atenção básica, substituindo as equipes "tradicionais" das UBS pelas equipes de saúde da família, não foi suficiente para proporcionar cobertura à população sem acesso ou com acesso precário a esse nível de atenção. Esses espaços geográficos ou núcleos populacionais desassistidos configuram o que um dos gestores do período caracterizou como buracos do "queijo suíço". Essa situação foi detectada e relatada em outro estudo, que avaliou o PSF no Município de São Paulo ${ }^{32}$.

A implantação do PSF por meio de parcerias com entidades privadas, justificada como forma para agilizar a implementação do programa, criou importante contradição. Deve-se considerar que o fundamento da agilidade para a contratação de pessoal, compras e manutenção serve tanto para justificá-las, quanto para agilizar demissões dessa força de trabalho, numa lógica de caráter gerencialista e com critérios que não respeitam o que se convencionou denominar de interesse do bem comum ${ }^{7,33}$. Logo, relações trabalhistas precárias ou não estáveis fragilizam o componente da força de trabalho que, no setor saúde, é estratégico e tem potência para dar continuidade e sustentação às políticas, no que se refere à sua configuração como política de Estado.

Para Di Pietro ${ }^{34}$, parceria e terceirização são velhas estratégias, com caráter fortemente ideológico, que contribuem para a mudança do papel do Estado e da Administração Pública. Dessa forma, o Estado não teria mais o papel de prestador direto de serviços, sendo necessário limitar suas competências e diminuir seu tamanho, para transformá-lo num Estado cujo papel principal seria o de estimular, apoiar e subsidiar a iniciativa privada ${ }^{34}$. 
Portanto, apesar das distintas orientações político-partidárias das gestões estudadas, observou-se que a terceirização de serviços e de estabelecimentos de saúde esteve presente desde o início da primeira gestão, inicialmente centrada no gerenciamento de pessoal para o PSF e na contratação de serviços de apoio diagnóstico. Na segunda gestão, constatou-se um aprofundamento dessa política chegando à terceirização da gerência de estabelecimentos e até mesmo de regiões de saúde.

\section{Referências}

1. Instituto Brasileiro de Geografia e Estatística. Cidades@: São Paulo (SP). http://www.ibge.gov.br/cidadesat/ (acessado em 25/Jul/2008).

2. Brasil. Lei $\mathrm{n}^{\circ} 8.080$ de 19 de setembro de 1990. Dispõe sobre as condições para a promoção, proteção e recuperação da saúde, a organização e o funcionamento dos serviços correspondentes e dá outras providências. Diário Oficial da União 1990; 20 set.

3. Brasil. Lei no 8.142 de 28 de dezembro de 1990. Dispõe sobre a participação da comunidade na gestão do Sistema Único de Saúde (SUS) e sobre as transferências intergovernamentais. Diário Oficial da União 1990; 31 dez.

4. Junqueira V. Saúde na cidade de São Paulo (1989 a 2000). 2a ed. São Paulo: Instituto Pólis/Pontifícia Universidade Católica de São Paulo; 2002.

5. Neder C. Organização do SUS em São Paulo: breve histórico. http://www.carlosneder.org.br/CN02/especiais/ (acessado em 20/Jun/2008).

6. Furtado LAC, Tanaka OY. Processo de construção de um distrito de saúde na perspectiva de gestores e médicos: estudo de caso. Rev Saúde Pública 1998; 32:587-95.

7. Paula APP. Administração pública brasileira: entre o gerencialismo e a gestão social. RAE Revista de Administração de Empresas 2005; 45:36-49.

8. Cohn A, Elias PEM, organizadores. O público e o privado na saúde: o PAS em São Paulo. São Paulo: Editora Cortez/Centro de Estudos de Cultura Contemporânea; 1999. 
9. Keinert TMM. Política pública de saúde, inovação e o Plano de Atendimento à Saúde do Município de São Paulo. RAE Revista de Administração de Empresas 1997; 37:78-85.

10. Yin RK. Case Study Research: design and methods. 2nd ed. Thousand Oaks: Sage; 1994.

11. Viana AL. Abordagens metodológicas em políticas públicas. Revista de Administração Pública 1996; 30(2):5-43.

12. Paim JS, Teixeira CF. Política, planejamento e gestão em saúde: balanço do estado da arte. Rev Saúde Pública 2006; 40 N Esp:73-8.

13. Sobrinho EJMA. Prefácio; São Paulo de volta ao Brasil e à Constituição. In: Sousa MF, Mendes A, organizadores. Tempos radicais da saúde em São Paulo: a construção do SUS na maior cidade brasileira. São Paulo: Editora Hucitec; 2003. p. $11-15$; p. 25-30.

14. Plenária Municipal de Saúde. Despacho da justiça a favor do Conselho. $\mathrm{http} /$ plenariamunicipalsaudesp.blog.terra.com.br/?m=200803\&page=3 (acessado em 25/Jul/2008).

15. Donnini OA. A reorganização da gestão de saúde em São Paulo. In: Sousa MF, Mendes A, organizadores. Tempos radicais da saúde em São Paulo: a construção do SUS na maior cidade brasileira. São Paulo: Editora Hucitec; 2003. p. 31-42.

16. Brasil. Portaria MS/GM no 1.399. Habilita o Município de São Paulo conforme o Anexo desta Portaria, na Gestão Plena do Sistema Municipal. Diário Oficial da União 2003; 23 jul.

17. São Paulo. Comunicado SMS nº 01. Diretrizes gerais para Secretaria Municipal de Saúde - documento 1. Diário Oficial do Município 2001; 25 jan.

18. São Paulo. Lei ${ }^{\circ}$ 13.399. Dispõe sobre a criação de Subprefeituras no município de São Paulo. Diário Oficial do Município 2002; 02 ago.

19. São Paulo. Comunicado SMS no 87. Adequação do sistema municipal de saúde às Subprefeituras. Diário Oficial do Município 2002; 15 ago.

20. São Paulo. Decreto $n^{\circ}$ 45.037. Dispõe sobre a organização do Sistema Único de Saúde no Município de São Paulo. Diário Oficial do Município 2004; 21 jul. 
21. São Paulo. Lei ${ }^{\circ}$ 13.271. Dispõe sobre a descentralização das ações e serviços de saúde no Município de São Paulo, com a criação de entidades autárquicas hospitalares de regime especial. Diário Oficial do Município 2002; 05 jan.

22. São Paulo. Portaria SMSP n ${ }^{\circ} 11$. Atribui responsabilidade pelo expediente das Coordenadorias de Saúde nas Subprefeituras satélite das regiões centro, leste, oeste e sul. Diário Oficial do Município 2005; 18 jan.

23. São Paulo. Decreto no 46.209 de 15 de agosto de 2005. Dispõe sobre a transferência das Coordenadorias de Saúde das Subprefeituras que especifica para a Secretaria Municipal da Saúde. Diário Oficial do Município 2005; 16 ago.

24. São Paulo. Decreto ${ }^{\circ} 47.107$ de 22 de março de 2006. Dispõe sobre a integração das Coordenadorias Regionais de Saúde com a rede hospitalar municipal, para gestão da rede de serviços de saúde. Diário Oficial do Município 2006; 23 mar.

25. Ministério da Saúde. Departamento de Atenção Básica. Evolução do credenciamento e implantação da estratégia saúde da família. http://dtr2004.saude.gov.br/dab/localiza_cadastro.php (acessado em 28/Jul/2008).

26. São Paulo. Comunicado SMS n ${ }^{\circ}$ 04. Diretrizes gerais para SMS - documento 2: implantação do Programa de Saúde da Família. Diário Oficial do Município 2001; 27 jun.

27. São Paulo. Portaria SMS no 3.822 de 15 de outubro de 2002. Aprova o Documento Norteador à organização da atenção básica na Cidade de São Paulo Programa de Saúde da Família - PSF. Diário Oficial do Município 2002; 16 out.

28. Sousa MF. O PSF na cidade de São Paulo trabalhando em parceria: o compromisso possível. Sousa MF, Mendes A, organizadores. Tempos radicais da saúde em São Paulo: a construção do SUS na maior cidade brasileira. São Paulo: Editora Hucitec; 2003. p. 91-4.

29. Carapinheiro G. Saberes e Poderes no Hospital. $2^{\mathrm{a}}$ ed. Porto: Afrontamento; 1993.

30. Vieira-da-Silva LM, Hartz ZMA, Chaves SCL, Silva GAP, Paim JS. Análise da implantação da gestão descentralizada em saúde: estudo comparado de cinco casos na Bahia, Brasil. Cad Saúde Pública 2007; 23:355-70. 
31. DiMaggio PJ, Powell WW. The iron cage revisited: institutional isomorphism and collective rationality in organizational fields. Am Sociol Rev 1983; 48(2):147-60.

32. Bousquat A, Cohn A, Elias PE. Implantação do Programa de Saúde da Família e exclusão sócio-espacial no Município de São Paulo, Brasil. Cad Saúde Pública $2006 ; 22: 1935-43$.

33. Chalant JF. O gerencialismo e a ética do bem comum: a questão da motivação para o trabalho nos serviços públicos. In: VII Congreso Internacional del CLAD sobre la Reforma del Estado y de la Administración Pública. http://unpan1.un.org/intradoc/groups/public/documents/CLAD/clad0043316.pdf (acessado em 20/Jun/2008).

34. Di Pietro MSZ. Parcerias na Administração Pública. $2^{\mathrm{a}}$ ed. São Paulo: Editora Atlas; 1997.

\section{Colaboradores}

N.R.S.Pinto contribuiu na elaboração dos métodos, na análise temática, na discussão dos resultados e na redação final deste artigo. S.M.Spedo e O.Y.Tanaka colaboraram na discussão dos resultados e na redação do artigo. N.R.S.Pinto, S.M.Spedo e O.Y.Tanaka participaram de todas as etapas da pesquisa.

\section{Agradecimentos}

A pesquisa que gerou os dados analisados neste artigo foi parcialmente financiada, na modalidade apoio à pesquisa, pelo Conselho Nacional de Desenvolvimento Científico e Tecnológico (Processo CNPq n ${ }^{\circ}$ 401903/2005-2) e pela Fundação de Amparo à Pesquisa do Estado de São Paulo (Processo Fapesp nº 2005/53846-8). 


\subsection{Artigo formatado para a revista Saúde e Sociedade}

O artigo “O desafio da direção única no Sistema Único de Saúde (SUS) em município de grande porte: o caso do Município de São Paulo, Brasil" foi formatado para ser apresentado aos editores do periódico Saúde e Sociedade, que é uma publicação da Faculdade de Saúde Pública, da Universidade de São Paulo, e da Associação Paulista de Saúde Pública, São Paulo (SP).

\section{Referências editoriais do periódico e comunicação autor(es) - editor}

- Artigos

a) Texto e referências - máximo de 20 páginas (incluindo referências, gráficos e tabelas)

b) Referências - em ordem alfabética (ABNT) e citação no manuscrito, entre parêntesis, pelo nome do(s) autor(es) em letras minúsculas

c) Resumo - máximo de 250 palavras

d) Palavras chaves -3 a 6

- Envio do artigo para o periódico

2 de fevereiro de 2009

- Situação que se encontra o artigo

$\rightarrow$ EM AVALIAÇÃO - SEM RESPOSTA 


\section{O desafio da direção única no Sistema Único de Saúde (SUS) em município de grande porte: o caso do Município de São Paulo, Brasil ${ }^{2}$ \\ The challenge of unified health services management in the Brazilian National Health System (SUS) in a large municipality: the case of São Paulo city, Brazil}

\section{Nicanor R. S. Pinto}

Médico Sanitarista do Departamento de Medicina Preventiva (Unifesp), Doutorando em Saúde Pública (Faculdade de Saúde Pública da USP), Mestre em Ciências (Unifesp-EPM)

End.: Rua Botucatu 740, Vila Clementino, CEP 04123-062, São Paulo, SP, Brasil E-mail: nicanor@medprev.epm.br

\section{Sandra Maria Spedo}

Médica Sanitarista do Departamento de Medicina Preventiva (Unifesp), Doutoranda em Saúde Pública (Faculdade de Saúde Pública da USP), Mestre em Saúde Coletiva (Unicamp)

End.: Rua Botucatu 740, Vila Clementino, CEP 04123-062, São Paulo, SP, Brasil E-mail: smspedo@medprev.epm.br

\section{Oswaldo Yoshimi Tanaka}

Professor Titular da Faculdade de Saúde Pública (USP)

End.: Av. Dr. Arnaldo 715, Cerqueira César, CEP 01246-904, São Paulo, SP, Brasil E-mail: oytanaka@usp.br

\footnotetext{
${ }^{2}$ A pesquisa que gerou os dados trabalhados neste artigo foi financiada, parcialmente, pelo CNPq (Processo CNPq No 401903/2005-2) e pela FAPESP (Processo Fapesp No 2005/53846-8).
} 


\section{Resumo}

A construção da direção única na saúde constitui-se um desafio para a gestão local do SUS, particularmente, para municípios de grande porte. Este artigo analisou o processo de implementação do SUS no Município de São Paulo, visando identificar estratégias para viabilizar uma direção única, no período de 2001 a 2008. Com base em um estudo de caso, foram utilizados dados obtidos principalmente de informantes privilegiados da gestão e de documentos de gestão. $O$ conceito de integração sanitária foi utilizado como categoria analítica. Foram analisados movimentos e estratégias dos atores institucionais envolvidos diretamente na gestão do SUS, os gestores municipal e estadual. Observaram-se avanços institucionais como a municipalização das unidades básicas de saúde estaduais e a habilitação do município na gestão plena do sistema municipal. Apesar dessa condição de gestão e da identidade político-partidária entre os governos municipal e estadual desde 2005, constatou-se a coexistência de dois subsistemas públicos de saúde pouco integrados. Um municipal, que concentrava os serviços de atenção básica; outro estadual, que concentrava parte considerável dos serviços de média e alta complexidades. Instrumentos de gestão adotados, como o sistema de regulação, mostraram-se frágeis para superar a falta de integração entre os referidos subsistemas. Como implementar a direção única no SUS, implica em uma (re)divisão de recursos e poder, discute-se que não bastam normas nem instrumentos de gestão para viabilizá-la. É um desafio estratégico para o SUS implementar processo de negociação, envolvendo os atores institucionais e políticos, visando a pactuação de um projeto político na saúde.

Palavras chave: Direção Única; Gestão em Saúde; Integralidade; Integração de Serviços de Saúde; Política de Saúde; Sistema Único de Saúde 


\begin{abstract}
The construction of the unified health management is a challenge for the local Brazilian National Health System (SUS) management, specialy in large cities. This article analised the implementation process of the SUS in São Paulo city. Its objective was to identify strategies to implement the unified health management, in the period from 2001 to 2008 . The method used was a case study and data collection was based on management documents and interviews. The concept of health services integration was used as analytical category. Movements and strategies of the SUS institutional actors in São Paulo city were analised. There were institutional improvements registered like the municipalization of the state health centers and the habilitation of São Paulo on the SUS total municipal health system management status. Besides this SUS management status and the political party identity between state and city governments since 2005, there were two public health subsystems apart with litle integration between them. The city one, wich gathered primary health care services, and the state one, gathering most of the secondary and tertiary health services. The management tools used, such as regulation system, proved to be fragile to overcome the lack of integration among those health subsystems. Since the implementation of a unified health management on SUS implicates in a (re)division of resources and power, rules and management tools are not enough to make it feasible. To implement a negotiation process between the institutional and political actors envolved of a common political project on health is a strategic challenge.
\end{abstract}

Key words: Unified Health Management; Health Management; Integrality; Health Services Integration; Health Policy; Single Health System 


\section{Introdução}

Viabilizar uma "direção única", em cada esfera de governo, continua sendo um grande desafio para a efetiva implementação do Sistema Único de Saúde (SUS) no Brasil. Em termos práticos, esse desafio se coloca de forma mais contundente para municípios de grande porte, motivado pelo fato de que a maior parte dos serviços de média e alta complexidade (MAC), tanto públicos, quanto privados, vinculados ao SUS, está concentrada nesses municípios e, particularmente, nas capitais de estado. O conceito da direção única no SUS foi incorporado na Constituição Federal de 1988, em seu artigo 198, que criou o sistema de saúde brasileiro e delineou suas principais diretrizes político-institucionais, sendo associado à diretriz da descentralização das ações e serviços de saúde. Além da Constituição, esse conceito foi retomado na legislação que regulamentou e institucionalizou o SUS no país, sendo incorporado em vários artigos da Lei $\mathrm{n}^{\circ}$ 8.080/90. Enquanto competência atribuída a cada esfera de governo, a direção única foi identificada com o Ministério da Saúde, no âmbito da União, e com as respectivas Secretarias de Saúde ou estruturas equivalentes, no âmbito dos Estados, Municípios e Distrito Federal (Brasil, 1990).

Para facilitar o entendimento desse processo, vale fazer um breve resgate do contexto histórico e institucional do período pré-constituinte. Nesse sentido, nas décadas de 1970 e 1980, a organização das ações e serviços públicos de saúde brasileiros estava centralizada - política, administrativa e financeiramente - no governo federal e fragmentada em dois subsistemas principais. Um deles era vinculado ao Ministério da Previdência Social e o outro era vinculado ao Ministério da Saúde e, de forma 
diferenciada, às Secretarias de Saúde dos estados (Mendes, 1993; Arretche, 1999; Gerschman e Santos, 2006).

Outra questão relevante a ser incorporada à discussão sobre o tema da direção única no SUS se refere ao federalismo. Assim, deve-se considerar que de 1964 a 1985, no período da ditadura militar, o federalismo brasileiro podia ser caracterizado como de tipo hegemonicamente competitivo, onde, além da centralização do governo federal, havia o predomínio de disputas dos governos estaduais e municipais por projetos e outros recursos, em particular, os financeiros. Nesse contexto, o processo de redemocratização do país pode ser caracterizado como uma luta para superar a ditadura militar e seu modelo de federalismo, também identificado como sendo autoritário, centralizado, burocrático. Na época, associava-se a idéia de que a nova democracia devia, necessariamente, descentralizar poder e garantir mais autonomia política, administrativa e financeira - para estados e municípios. Em função da presença e importância do movimento municipalista no processo constituinte, o conceito de descentralização foi deslocado e, na prática, identificado com o de municipalização. Um dos resultados desse processo foi que os municípios brasileiros ganharam a condição de entes federados, de forma semelhante aos estados e a União, o que, no cenário internacional, constitui-se uma singularidade do federalismo brasileiro (Mendes, 1998; Arretche, 1999; Viana e col., 2002; Arretche, 2003; Abrucio, 2005).

No período que se estendeu do início da década de 1980 até pouco depois do processo constituinte, foram implementadas duas reformas do modelo assistencial vigente, as Ações Integradas de Saúde (AIS) e, na sequência, o Sistema Unificado e Descentralizado de Saúde (SUDS). Embora delineadas para racionalizar recursos 
face à crise da Previdência, foram consideradas estratégicas para o processo de reforma sanitária e do próprio SUS (Paim, 1986; Arouca, 1988). Ressalte-se o fato que, ambas experiências seguiram diretrizes, posteriormente, incorporadas à base jurídico-legal que criou o SUS, como a descentralização e a integração de serviços de saúde, envolvendo serviços e estabelecimentos de saúde dos ministérios da Previdência e da Saúde, bem como das Secretarias de Saúde estaduais e algumas municipais.

A implementação do SUS vem sendo orientada e sustentada por meio de instrumentos normativos do MS, que com a incorporação do antigo Instituto Nacional de Assistência Médica da Previdência Social (INAMPS), assumiu a condição de gestor único, de fato, do sistema, na esfera federal de governo. $\mathrm{Na}$ década de 1990, foi registrado um intenso processo de descentralização da política de saúde e da parcela federal de seu financiamento, de forma direta - "fundo a fundo" para os municípios, induzida por meio de Normas Operacionais Básicas (NOBs). Esses instrumentos de gestão e regulação do processo incorporaram mecanismos de habilitação dos municípios a determinadas condições de gestão, desde que fossem preenchidos alguns critérios. Em avaliação sobre o papel das três NOBs editadas nessa década sobre a extensão da descentralização, registrou-se um aumento considerável na porcentagem de municípios que "aderiram" ao SUS - inicialmente por convênio e, depois, por habilitação em distintas condições de gestão -, saindo de um patamar de 22\%, nos anos de vigência da NOB de 1991, e atingindo o de 99,6\% com a NOB de 1996 (Levcovitz e col., 2001; Souza, 2003; Oliveira, 2003; Arretche, 2003). 
Paralelamente ao movimento de descentralização e municipalização da política de saúde registrado no país, essa década também registrou dois fatos marcantes para o SUS e para o MSP, no âmbito da integração dos serviços de saúde. O primeiro, de caráter nacional, foi a extinção do INAMPS, com a proposta de que as suas "funções, competências, atividades e atribuições [...] [fossem] absorvidas pelas instâncias federal, estadual e municipal gestoras do Sistema Único de Saúde” e que seus serviços de saúde fossem "doados ou cedidos a municípios, estados e Distrito Federal” (Brasil, 1993). O segundo, de caráter local, foi a não adesão ao SUS e a subsequente criação de um Plano de Atendimento à Saúde (PAS) como uma política própria e alternativa ao mesmo, no Município de São Paulo, durante os períodos das gestões municipais 1993-1996 e 1997-2000 (Cohn e Elias, 1999). O PAS pode ser caracterizado como uma das primeiras experiências de gestão não estatal da saúde, de lógica gerencialista, implementada em município de grande porte no país. A implementação do PAS, além de desorganizar a estrutura administrativa da secretaria municipal de saúde (SMS-SP), organizou um modelo assistencial baseado em cooperativas de profissionais de saúde organizadas exclusivamente para essa finalidade (Pinto e col., 2009).

Em um contexto de disputa entre várias forças políticas e partidárias, implicando em alternância no poder com distintas prioridades políticas, a partir da gestão 20012004, foi registrado o início do processo de (re)construção e institucionalização do SUS no Município de São Paulo. No plano da gestão do SUS na capital, marcaram o período a habilitação do município na gestão plena da atenção básica, bem como a subsequente municipalização das unidades básicas de saúde (UBSs) e centros de saúde (CSs) vinculados até então à secretaria de estado da saúde (SES-SP). Nesse 
sentido, pode-se configurar a construção de um comando único da atenção básica no município, sob gestão de fato e de direito da SMS-SP. Em julho de 2003, o município foi habilitado na condição de gestão plena do sistema municipal, de acordo com a Norma Operacional da Assistência à Saúde (NOAS-SUS) de 2002 (Pinto e col., 2009).

Essa Norma retomou a idéia da direção única, por esfera de governo, expressa nas diretrizes político-institucionais do SUS, com o conceito de comando único ao tratar da regulação e programação dos serviços de média e alta complexidades (MAC). As funções de organização e regulação destes serviços, em municípios habilitados na gestão plena do sistema municipal de saúde, deveriam ser da competência do município.

Nesse contexto, o objetivo deste estudo foi avaliar movimentos e ações realizados pelos atores institucionais, a SMS-SP e a SES-SP, com referência na "imagem objetivo" da integralidade, no sentido da construção de uma direção única do SUS no Município de São Paulo.

\section{Métodos}

O objeto da pesquisa foi uma avaliação de políticas de saúde do Município de São Paulo (SP), no período de estudo foi de 2001 a 2008, com referência na incorporação da integralidade da assistência à saúde no sistema. Foram contempladas experiências de duas gestões municipais, as dos períodos 2001-2004 e 2005-2008.

O desenho deste estudo foi baseado em uma avaliação de processo (Weiss, 1998; Walt e col., 2008). A estratégia metodológica adotada foi a do estudo de caso, que pode ser caracterizada como uma investigação empírica sobre um fenômeno 
contemporâneo e complexo, realizada em seu contexto e com limites imprecisos, entre fenômeno e contexto (Yin, 1994). Em função dessas características, esse método tem sido aplicado por distintos pesquisadores em estudos sobre políticas e gestão públicas (Yin, 1994; Walt e col., 2008).

Os dados coletados tiveram como principais fontes de evidência: (a) informantes privilegiados ou "chaves" do processo de gestão - por meio de entrevistas -; (b) documentos de gestão; e (c) observação participante.

Aos gestores, da SMS-SP, e assessores técnicos, da SMS-SP e da SES-SP, selecionados foram aplicados entrevistas individuais de tipo não-estruturadas. Os objetivos da pesquisa eram apresentados aos entrevistados, que falavam livremente sobre os mesmos por cerca de 40 minutos. Quando temas de interesse eram abordados nessa fala inicial, os autores estimulavam o tema explorando detalhes. As entrevistas foram realizadas por, pelo menos, dois dos autores, sendo que todas foram gravadas e, posteriormente, transcritas.

Os documentos de gestão analisados foram: documentos oficiais (decretos, portarias, relatórios, atas de reuniões) publicados ou disponibilizados em: Diários Oficiais; sítios institucionais; documentos internos, mesmo que em versões preliminares; e publicações de sujeitos da pesquisa.

A observação participante foi desenvolvida, com implicação de tipo periférico (Lapassade, 2005), por dois dos autores (NRSP e SMS) em reuniões plenárias do Conselho Municipal de Saúde, em Conferências Municipais de Saúde, em visitas a serviços e estabelecimentos de saúde da SMS-SP e em conversas com gestores e técnicos da gestão. Neste artigo, as informações obtidas por essa técnica foram 
usadas como forma de validar informações das outras fontes de evidência, em uma triangulação de fontes e técnicas.

O conceito de "integração sanitária”, em sua dimensão intra-setorial, foi escolhido como categoria analítica. Esse conceito diz respeito a ações e serviços do setor saúde e consiste em "agrupar órgãos díspares dentro de um plano e um programa de ação comuns; e reuní-los em um serviço que funcione como um todo harmônico sob uma chefia única” (Ramos, 1972, p. 6). Destaca-se que há afinidade conceitual entre este e o princípio da integralidade do SUS, expresso no artigo $7^{\circ}$, inciso II da Lei ${ }^{\circ} 8.080$ (Brasil.MS, 1990).

O material empírico foi analisado, tendo como referência a técnica da análise temática (Bardin, 2004). A identificação de temas sobre estratégias e movimentos da SMS-SP, e sua relação com a SES-SP, foi realizada a partir do material coletado pelas fontes de evidência e utilizando os seguintes critérios: destaque no discurso dos atores em entrevistas ou em documentos de gestão; e concordância de escolha entre os autores. Buscou-se respeitar a cronologia e a historicidade dos fatos e evidências, mas o eixo norteador principal desses achados foi seu conteúdo temático. São apresentadas seleções de trechos significativos dos discursos, editados pelos autores e, para preservar a identidade dos entrevistados, as seleções reproduzidas estão identificadas apenas com a função pública do entrevistado.

A análise buscou compreender, ainda, as relações entre "intenções", construídas e expressas na formulação das políticas, e "ações", que expressam a vida real e podem estar presentes na fase de implementação dessas políticas.

O projeto da pesquisa, que gerou os dados analisados neste artigo, foi aprovado pelos Comitês de Ética em Pesquisa da Faculdade de Saúde Pública (FSP-USP) e da SMS- 
SP (Processo CEP/SMS No 0084.0.162.207-05), respeitando os preceitos da Resolução 196/96 do Conselho Nacional de Saúde.

\section{Resultados}

O Município de São Paulo possui uma rede pública de serviços de saúde grande e bastante diversificada que, a partir de 2001, incorporou mais cerca de 200 unidades ambulatoriais com a municipalização dos CSs estaduais. Aquelas com espaço físico e estrutura melhores, foram transformadas em ambulatórios de especialidades (AEs); outras, incorporaram equipes do Programa de Saúde da Família (PSF); e a partir de 2005, outras, incorporaram um serviço de pronto atendimento denominado AMA (assistência médica ambulatorial). Esse movimento contribuiu para um aumento considerável desses dois tipos de estabelecimentos de saúde, entre aqueles vinculados diretamente à SMS-SP (Figura 1).

Desde 2003, a SMS-SP vem assumindo a gestão de MAC da rede privada contratada ou conveniada com o SUS, vinculados a 144 hospitais gerais e de especialidades, bem como aqueles vinculados a 1.849 ambulatórios e clínicas de especialidades (AEs e CEs). Mas, não conseguiu negociar e assumir a gestão da maioria dos serviços de MAC, vinculados aos 35 hospitais e 28 ambulatórios de especialidades que continuavam sob gestão exclusivamente estadual ou compartilhada entre a SES-SP e a SMS-SP (Tabela 1). Destacam-se a magnitude e a relevância da "rede" privada de hospitais e clínicas ambulatoriais - historicamente constituída - na conformação do SUS no município. 
Figura 1. Estabelecimentos de saúde ${ }^{(a)}$ vinculados à SMS-SP, por tipo e anocalendário selecionado. São Paulo (SP): 1992 a 2008.

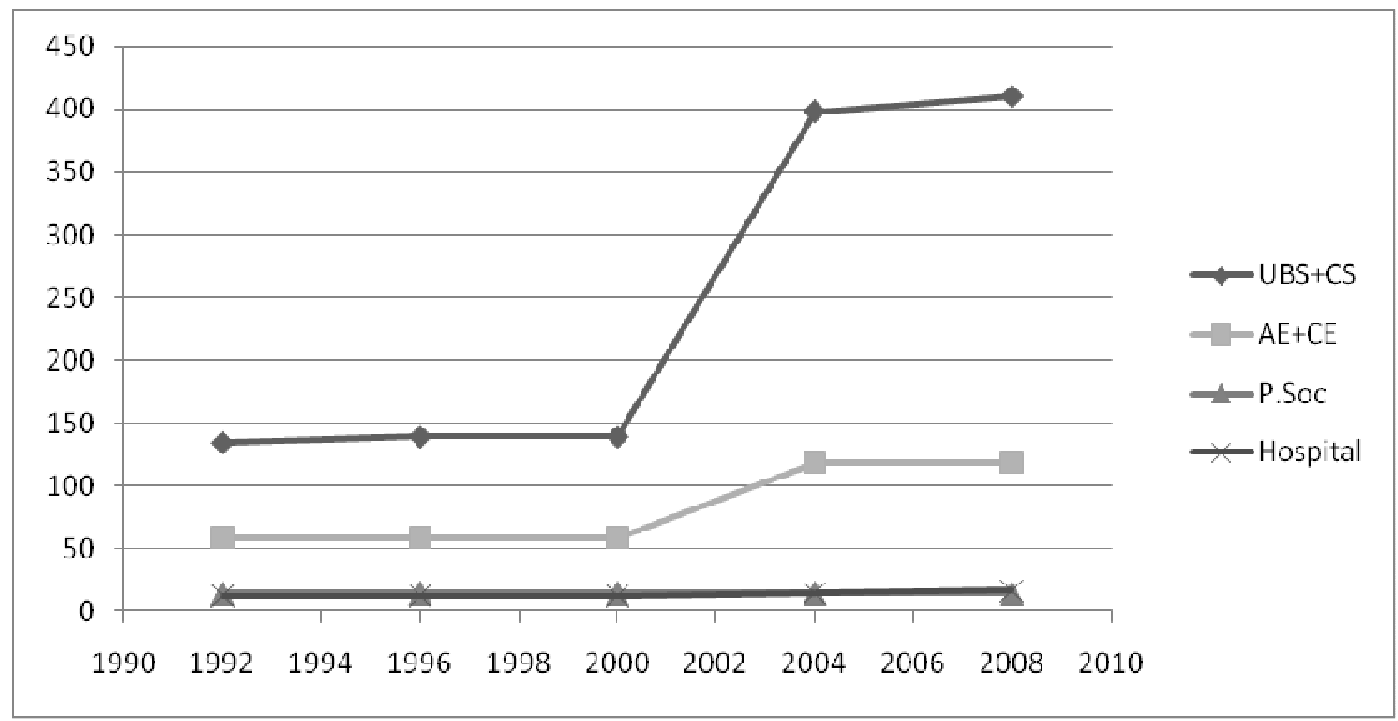

Fontes: Ceinfo (SMS-SP, 2008); Junqueira (2002); Cohn, Elias (1999).

(a) não inclui unidades AMA (Assistência Médica Ambulatorial), implantadas no período 20052008, porque a maioria delas estava acoplada a outros estabelecimentos: UBSs, CSs, AEs e P.Soc.

Tabela 1. Estabelecimentos de saúde instalados no município de São Paulo, por característica e esfera administrativa. São Paulo (SP): julho de 2008.

\begin{tabular}{lcccc}
\hline \multicolumn{1}{c}{ Característica } & \multicolumn{4}{c}{ Esfera Administrativa } \\
\cline { 2 - 5 } & Municipal & Estadual & Federal & Privada \\
\hline Tipo de Estabelecimento & 1 & 13 & - & 37 \\
• Hospital de Especialidades & 16 & 22 & 3 & 107 \\
- Hospital Geral & 115 & 19 & 1 & 1.849 \\
- Amb. e Clín. de Especialidades & 452 & 9 & - & 4 \\
- UBSs/CSs/Postos & & & & \\
Tipo de Gestão & 584 & 8 & 2 & 1.995 \\
- Municipal (SMS-SP) & - & 8 & 1 & 1 \\
- Estadual (SES-SP) & - & 44 & 1 & 1 \\
- Dupla & Fonte: CNES (Brasil.MS.Datasus, 2008). & & &
\end{tabular}


Nesse contexto, foram identificados movimentos e ações dos principais atores institucionais, relacionados com a conformação de uma direção única do SUS nessa capital: (a) construir a direção única do SUS sob gestão da SMS-SP; (b) manter todos os serviços estaduais de MAC sob gestão da SES-SP; e (c) implementar um Sistema de Regulação do SUS sob gestão da SMS-SP.

\section{- Construir a direção única do SUS sob a gestão da SMS-SP}

Na gestão municipal de 2001-2004, a municipalização dos serviços de MAC vinculados à SES-SP parece ter sido uma das principais estratégias para a construção da integralidade no sistema municipal. O gestor municipal do período 2001-2002, embora priorizasse a atenção básica (AB) e o PSF, assumia, pelo menos no discurso, que a integralidade da atenção era dependente de uma maior oferta de retaguarda hospitalar e de serviços de apoio diagnóstico e terapêutico (SADT), bem como da ordenação do sistema sob a direção única do município. Essa expectativa pode ser observada no trecho em que esse gestor relata o movimento da SMS-SP na busca de sua habilitação na condição de gestão plena do sistema municipal: "Estão em andamento as negociações, do repasse para a nossa gerência, dos quarenta hospitais estaduais e outros tantos serviços especializados estaduais sediados na capital e também o acompanhamento dos serviços de saúde privados, filantrópicos e lucrativos, conveniados com o SUS na cidade” (Sobrinho, 2003, p. 13).

A Secretaria baseava seu argumento na necessidade de melhorar a resolutividade dos serviços de saúde vinculados à $\mathrm{AB}$, sob gestão municipal, e enfatizava a sua participação na articulação com os serviços de MAC, sob gestão estadual, como identificado no trecho a seguir: "[Para] garantir uma maior resolutividade da rede básica [...] é fundamental garantir a retaguarda de especialidades, de SADT ou de 
internações hospitalares. [...] Apesar da SMS não ser gestora da maior parte dos mesmos, é imperativa sua participação na definição das referências e contrareferências para efetivamente garantir uma assistência integral" (Relatório de Gestão SMS-SP, 2002).

Contudo, até o final de 2002, quando a SMS-SP ainda encontrava-se habilitada na gestão plena da atenção básica, não havia uma proposta concreta para a negociação da municipalização dos serviços de MAC. Apenas em meados de 2003, após troca do gestor municipal da saúde, o município foi habilitado na gestão plena do sistema municipal. Mas, sem a esperada municipalização dos serviços estaduais de MAC. O secretário municipal da saúde desse período argumentou sobre a dificuldade de se garantir a integralidade sistêmica sem a direção única do SUS no município, nos seguintes termos: "Como dá pra discutir a questão da integralidade, se uma parte da rede ambulatorial especializada não tem nada a ver com a prefeitura? [...] Se o estoque de consultas que tenho para oferecer para a atenção básica ocorre de maneira aleatória? Se meu acesso hospitalar não tem nenhum nexo com o processo de atenção básica à saúde? Se a porta de entrada à dimensão hospitalar é o prontosocorro?" (gestor B).

Uma das dificuldades presentes na negociação com a SES-SP, desde seu início, foi associada com o contexto político e eleitoral, particularmente as eleições de 2004, envolvendo a disputa das administrações municipais. Nesse sentido, embora legítimos e democráticos, os distintos interesses político-partidários em jogo na disputa pela prefeitura do Município de São Paulo tiveram um importante papel para a suspensão dessa pactuação, como avaliou o gestor municipal do período: “Caminhou relativamente bem, até começar a eleição. [...] A partir de abril/maio de 
2004, essas coisas foram congeladas e nós não avançamos mais praticamente nada" (gestor B).

Outra dificuldade observada nessa negociação entre a SMS-SP e a SES-SP era atribuída à falta de recursos financeiros novos e ao próprio fato de que o município teria aderido ao SUS tardiamente, em relação aos demais municípios do estado, como relatou o gestor municipal da época: “O Estado, num primeiro momento topou entrar, mas não queria rediscutir nenhuma distribuição de recursos. [...] Falaram: 'Olha, vocês chegaram por último.' [...] 'O que sobrou da PPI [Programação Pactuada e Integrada] do Estado é isso!'” (gestor B).

Constatou-se que essa imagem objetivo de construção de uma direção única do SUS no MSP, sob a direção da SMS-SP, prevaleceu como uma das principais estratégias da gestão municipal até o final da administração 2001-2004 (Plano de Ação SMS-SP, 2004).

No período da gestão 2005-2008, com a mudança do governo municipal, detectou-se uma concordância dos três primeiros secretários com a tese da necessidade de construção de uma direção única do SUS na capital. Mas, para alcançar essa imagem-objetivo, a estratégia parece ter sido redirecionada. Entre 2005 e 2006, constatou-se que a principal estratégia adotada pela SMS-SP foi tentar construir uma direção única do SUS, por meio da implementação de instâncias de pactuação regionais, conforme pronunciamento do gestor ao Conselho Municipal de Saúde: "Estamos em parceria com a Secretaria de Saúde do Estado para que os Hospitais [sob sua gestão] entrem nessa composição, dessas microrregiões, para que a gente possa organizar e, de fato, regular [o SUS] São Paulo" (São Paulo.CMS, 2005, p. 8). 
Cabe destacar que a estratégia não estava mais centrada na municipalização dos estabelecimentos e serviços da MAC vinculados à SES-SP como na gestão anterior. Por outro lado, foi possível identificar que a SES-SP, não compartilhava com o diagnóstico e o projeto defendidos por SMS-SP, como evidenciado no trecho da entrevista: "Uma instância nova ou uma CIR efetiva, prefeitura e estado, que haja representantes, representantes representativos das duas partes não tem ainda. Mesmo depois de 2003, [...] é muito independente" (assessor de gabinete - CSS da SES-SP).

Foi possível identificar um processo de integração político-institucional entre a SMSSP e a SES-SP, iniciado em 2006, para viabilizar um programa de atenção maternoinfantil, incluindo o acesso regulado ao parto, denominado de Rede de Proteção à Mãe Paulistana, conforme o seguinte trecho: "Na relação com o Estado, não temos problema! [...] O melhor exemplo é o 'Mãe Paulistana'. [...] Todas as maternidades municipais, públicas ou federais, privadas contratadas do município ou do estado. Todas elas têm seus leitos disponibilizados para o município. Sob gestão do município!” (gestor E).

\section{- Manter todos os serviços estaduais de MAC sob gestão da SES-SP}

Desde a década de 1990, o acesso aos serviços de MAC era organizado por meio de uma central de vagas para consultas em ambulatórios de especialidades isolados, sob gestão estadual, como pode ser observado no seguinte trecho: "A integração Município-Estado, [...] se baseia naquela famosa grade, que está sendo praticada há mais de 10 anos. [...] O Estado dispunha de um contingente grande de consultas para serem oferecidas pra população. [...] Criou-se, então, a lógica do 'call center', que é a central de regulação para todos esses ambulatórios e alguns hospitais. [...] 
Hoje, a unidade básica de saúde tem dois caminhos para encaminhar os pacientes [...]: um é o 'call center', outro é os acordos regionais" (assessor de gabinete - CSS da SES-SP).

A oferta de consultas especializadas através do call center foi organizada, de forma centralizada e informatizada em que eram disponibilizadas para as distintas regiões do município, por meio de cotas. Embora tivesse uma lógica de funcionamento de caráter racionalizador em função de sua dimensão e conseqüentes dificuldades de acesso, no Município de São Paulo esse mecanismo apresentou um paradoxo operacional em sua gestão. Apesar da dificuldade de acesso a serviços de MAC no município, as consultas especializadas agendadas pelo call center apresentavam porcentagens altas de "perdas" ou "faltas", como relatou o assessor do gestor estadual: “ $O$ 'call center' foi tentado, inicialmente, como uma solução para agendamento do ambulatório. [...] O paciente vai até o balcão e apresenta a solicitação do médico. Como o 'call center' não dá resposta imediata, o usuário é orientado a ir para casa e voltar depois de um tempo para saber quando foi agendada a consulta dele. Se ele não volta, essa consulta é reagendada e perdida. [...] [A taxa dessa perda] na primeira consulta, [era] em torno de 40\%; e nas consultas de retorno, em torno de 20\%. Em algumas unidades, teve até $60 \%$ na primeira consulta" (assessor de gabinete - CSS da SES-SP).

Por outro lado, alguns hospitais estaduais que dispunham de ambulatórios de especialidades realizavam acordos regionais, envolvendo instâncias de coordenação ou supervisão regionais da SMS-SP. Esses acordos eram possíveis tendo em vista os excedentes de serviços de MAC mais do que por um planejamento para responder a necessidades do sistema de saúde, sendo que, por vezes, esses acordos produziam 
contradições entre uma lógica centrada nos interesses dos hospitais e as necessidades das UBSs, que o assessor entrevistado caracterizou: "Nos acordos regionais, $[. .$.$] o$ raciocínio é sempre com a economia interna da unidade [hospital]. Acaba sendo disponibilizado o excedente. O excedente nem sempre é necessidade da rede básica. [...] Os cirurgiões da especialidade [P] tinham interesse e abriam possibilidade de consulta ambulatorial e não era nada ocupado. Mas, a rede básica não tem demanda! [...] Não tinha necessidade!” (assessor de gabinete - CSS da SES-SP).

Em 2005, coincidindo com o início da nova gestão no Município de São Paulo, com o argumento de era "papel do Estado identificar estabelecimentos hospitalares de referência e gerir sistemas públicos de alta complexidade, de referência estadual e regional, [...] e gerir as unidades que permaneçam em sua organização administrativa” o governo do Estado implementou, por meio do Decreto $\mathrm{n}^{\circ} 49.343$, uma grande reorganização da estrutura administrativa da SES-SP. Nessa reforma, uma antiga Coordenadoria de Saúde da Região Metropolitana da Grande São Paulo foi transformada em uma nova Coordenadoria de Serviços de Saúde (CSS), na qual foram vinculados e subordinados todos os estabelecimentos e serviços assistenciais da SES-SP sediados na capital (São Paulo, 2005). No final de 2006, por meio de outro Decreto, o governo do Estado fortaleceu a estrutura da nova coordenadoria, reorganizando suas competências e reafirmando o vínculo e a subordinação institucionais dos estabelecimentos e serviços de saúde, contemplados no decreto anterior, à CSS da SES-SP e dos "Prontos-Socorros e outros serviços do Sistema Único de Saúde - SUS/SP, criados por lei ou decreto e não mencionados expressamente neste decreto, que estão ou vierem a estar sob gestão da Secretaria da Saúde” (São Paulo, 2006). 
Nesse contexto, o que se pode evidenciar foi um movimento, por parte da gestão estadual, delineando e consolidando um projeto institucional para a SES-SP e para seus serviços de MAC. Apesar da eleição da mesma frente político-partidária do governo estadual no Município de São Paulo em 2004, a questão da construção da direção única do SUS no município ou mesmo da criação de mecanismos ou instâncias para apoiar um processo de integração entre a SMS-SP e a SES-SP não foram implementadas de forma semelhante aos avanços logrados com programa “Mãe Paulistana". Dessa forma, a implementação dessa reforma administrativa na SES-SP institucionalizou seu papel de gestora, de fato e de direito, de todos os serviços de MAC vinculados a ela e sediados na capital.

\section{- Implementar um Sistema de Regulação do SUS sob gestão da SMS-SP}

Considerando os problemas relatados para se construir uma direção única do SUS na capital, por meio da municipalização dos serviços de MAC vinculados à SES-SP, a SMS-SP buscou construí-la por meio da negociação de uma regulação do sistema, em que a gestão (única) do SUS ficasse sob a direção da SMS-SP, como se evidenciou na entrevista: "A negociação com a Secretaria Estadual de Saúde para assumir não a gestão das unidades ambulatoriais do Estado, mas as agendas das unidades ambulatoriais. Era esse o projeto: aquela história de gerência e gestão. Não quero fazer a gerência! Quero a gestão dos serviços!” (gestor B).

No início de 2003, no processo de negociação para a habilitação do Município de São Paulo na gestão plena do sistema municipal, foi considerada prioridade a implementação de um sistema de regulação do SUS na capital, pela SMS-SP. Essa política ganhou expressão material através da criação de uma Central de Regulação Municipal e de cinco Centrais de Regulação Regionais (São Paulo.SMS, 2003). Na 
busca de viabilizar a gestão do acesso a exames, a consultas de especialidades e a leitos hospitalares, a direção da SMS-SP mobilizou os recursos necessários para organizar um sistema informatizado que pudesse avaliar, em tempo próximo ao real, a disponibilidade de acesso a esses recursos de MAC no município.

Essa proposta de regulação era fundamentada na visão de que, em termos macroestruturais, não havia falta de leitos hospitalares no Município de São Paulo. Segundo o gestor que desencadeou esse processo, o que poderia haver era uma certa irracionalidade em seu uso ou, no máximo, uma falta de leitos localizados, em algumas regiões: “Leito, na cidade, não falta! [...] É só uma questão de conforto, por redirecionamento do fluxo de atendimento. [...] Mas, não falta leito. Falta racionalidade no atendimento. Tirar da porta quem não tinha que estar no hospital. Tirar da porta do hospital" (gestor B).

Nesse sentido, o gestor municipal conseguiu negociar diretamente com o gestor federal, mobilizando recursos financeiros próprios e do Ministério da Saúde, para desenvolver um programa informatizado, a partir de um software do ministério: “Tínhamos um sonho, [...] um 'software' gerenciando tudo isso. Fizemos um convênio com o Ministério e assumimos o 'software' de regulação do ministério. [...] A implantação começou e o prefeito $[\mathrm{S}]$ deu continuidade. Informatiza $100 \%$ da rede e das relações da rede com o sistema” (gestor B).

O novo software foi denominado Sistema Integrado de Gestão Assistencial (SIGA), que ainda precisava ser aprimorado e implantado nos estabelecimentos e serviços de saúde da capital. No final desse período de gestão, uma nova portaria propiciou um desenho organizacional mais articulado desse Sistema, criando inclusive uma Coordenação de Integração e Regulação do Sistema (São Paulo.SMS, 2004). 
Esse processo foi finalizado em meados de 2007, quando a SMS-SP institucionalizou a obrigatoriedade de uso do SIGA Saúde, como o programa foi denominado, por todas as unidades de saúde municipais (São Paulo.SMS, 2007). Ao final do período de estudo, em julho de 2008, o que se pode constatar foi a coexistência dos dois mecanismos para agendar consultas especializadas: o call center, sob gestão da SESSP; e o SIGA Saúde, sob gestão da SMS-SP. Nessa época, os serviços que concentravam atividades da atenção básica, vinculados à SMS-SP, conseguiam acessar diretamente a agenda disponibilizada pelo call center.

Apesar da implantação do novo sistema de regulação do SUS, o gestor municipal da saúde do Município de São Paulo continuava tendo dificuldades concretas para fazer a gestão e regular de fato o acesso aos serviços de MAC, mesmo a serviços sob gestão formal isolada ou compartilhada da SMS-SP, como expressou o gestor desse período: "Grandes hospitais, que já vinham com uma história com o Estado, que são os grandes prestadores de alta complexidade, estamos passando, pouco a pouco, a regular tudo. [...] Queremos chegar a regular! [...] A maior dificuldade é a tal da alta complexidade!" (gestor E).

\section{Discussão}

O caso do Município de São Paulo é singular e, em alguma medida, paradoxal no cenário nacional. No contexto do novo federalismo brasileiro, esse município, além da autonomia política respaldada constitucionalmente, tem autonomia administrativa e fiscal que possibilitaram-no, em passado recente, implementar uma política de nítida confrontação com o SUS, como foi a experiência do PAS. 
A partir de 2001, quando priorizou a implementação do SUS, teve autonomia política, administrativa e técnica para, rapidamente, ser habilitado na gestão plena da atenção básica e, na seqüência, assumir a gerência e a gestão de um conjunto de cerca de 200 CSs estaduais. Desde 2003, após ter sido habilitada na gestão plena do sistema municipal, a SMS-SP vem assumindo a gestão da quase totalidade dos serviços de MAC da rede privada contratada ou conveniada com o SUS. Mas, o pacto negociado com a SES-SP só garantiu a condição de co-gestão na rede estadual de MAC. Não conseguiu negociar um pacto com a SES-SP para assumir a gestão sequer dos serviços estaduais de média complexidade vinculados, tanto a ambulatórios, como a hospitais gerais ou especializados não-universitários.

Foi possível identificar evidências que a SMS-SP, para ser habilitada na gestão plena do sistema municipal, teve que abrir mão da gerência dos serviços de MAC estaduais na negociação com a SES-SP e o Ministério da Saúde. Manteve-se a gerência da rede de estabelecimentos hospitalares e ambulatoriais especializados estaduais com a SES-SP, ainda que alguns sob gestão compartilhada com a SMS-SP. Dessa forma, para garantir a integralidade sistêmica na assistência, a gestão municipal do SUS no Município de São Paulo, em alguma medida, ficou dependente da SES-SP - que possui e organiza a maioria dos recursos de MAC públicos - e do setor privado - que deveria atuar de forma complementar -, mas é estratégico para sua viabilidade.

A estratégia de se construir um sistema de regulação que ampliasse a capacidade de gestão da SMS-SP sobre os serviços de MAC vinculados ao SUS mostrou-se limitada. É importante considerar que, na década de 1990, a regulação do SUS no município foi criada e implementada, na SES-SP. Seja porque o PAS, enquanto foi mantido, se organizava de forma independente e paralela ao SUS, seja porque a rede 
estadual de estabelecimentos de saúde era maior do que a municipal, tanto em UBSs, quanto em hospitais e ambulatórios de especialidades.

Cabe lembrar que, mesmo na referida prática dos "acordos regionais", os hospitais estaduais tinham autonomia e poder para ofertar - ou não - serviços para as regionais da SMS-SP. Nesse sentido, o relato do assessor da SES-SP, que inclusive tinha uma função gestora, de direção e coordenação formais, sobre os referidos hospitais e, conseqüentemente, sobre o papel e a lógica de funcionamento dos hospitais estaduais pode servir como um bom analisador desse tema: "O hospital não se sente responsabilizado, do ponto de vista de instância secundária da região. Hospital tem um papel de hospital! [...] A porta do hospital é sua grande motivação! [...] A responsabilidade do hospital é dar conta do pronto-socorro. [...] Boa parte dos nossos hospitais se tornaram grandes retaguardas de pronto-socorro" (assessor de gabinete - CSS da SES-SP).

Há que se reconhecer que a fragilidade dessa estratégia não estava no instrumento de gestão implementado em si, que era necessário e que teve sustentação técnica e política por duas gestões. O SIGA Saúde pode, inclusive, ser destacado como um exemplo da capacidade da gestão municipal, que mobilizou recursos e implementou um programa consistente de controle, monitoramento e oferta de consultas e exames especializados e leitos hospitalares. Sua fragilidade pode estar associada mais ao fato de não ter e não elaborar um projeto para lidar com o poder institucional e histórico dos hospitais, bem como sua grande autonomia em relação ao restante da rede de serviços de saúde do SUS.

Outra fragilidade dessa estratégia que deve ser considerada está relacionada ao fato de que um sistema informatizado, por melhor que seja, não consegue garantir o 
acesso a serviços gerenciados por outros - SES-SP e prestadores privados -, sem o concurso de um processo de negociação em que se superem os problemas de fluxo e as divergências. Assim, o gestor municipal da saúde teve que normatizar, por meio de portaria específica, uma determinação visando a "obrigatoriedade do uso do Sistema de Informação SIGA Saúde - Módulos Agenda Local e Regulada por todas as Unidades de Saúde, sejam próprias e municipalizadas” (São Paulo.SMS, 2007). Contudo, essa norma não tinha poder sobre os ambulatórios e hospitais estaduais, que concentravam os serviços de MAC. Em junho de 2007, esse gestor reconhecia a necessidade da SMS-SP negociar um processo articulado ou integrado com a SES-SP para viabilizar a regulação do SUS no município, bem como seu potencial: “Na hora que tivermos a regulação na mão da gente, evidentemente o SUS passa a existir! [...] Estamos negociando, e vamos fazer, a nossa regulação junto com o Estado! [...] Se conseguir montar essa regulação, vou ficar muito orgulhosa! [...]Se São Paulo conseguir uma regulação junto com o Estado, isso pode facilitar a vida de todo mundo, principalmente do usuário!” (gestor E).

Contudo, esse processo parece ser mais complexo, como foi evidenciado posteriormente. Em 2008, após longo processo de negociação entre gestores, baseado em novo instrumento de descentralização e regulação do SUS - o Pacto pela Saúde envolvendo o Ministério da Saúde, a SES-SP e as SMSs -, destacava-se o fato de São Paulo ser o único município, entre os de grande porte, que ainda não tinha assinado o "Termo de Compromisso de Gestão Municipal”.

No plano mais político, em que pese o fato de, desde o início de 2005, as duas gestões - estadual e municipal - serem da mesma frente político-partidária, não houve evidências de qualquer progresso em termos de negociação e construção de 
uma direção única do SUS no município. Deve-se considerar que, no início da gestão 2005-2008, a estratégia da SMS-SP esteve centrada em viabilizar mecanismos interinstitucionais regionais para integrar suas instâncias regionais com serviços da SES-SP. Essa iniciativa visava uma melhor articulação e integração entre os gestores dos dois subsistemas para facilitar e racionalizar o acesso da população atendida na rede básica municipal ou municipalizada aos estabelecimentos de MAC sob gestão estadual. Mas, essa estratégia de regionalização da saúde enfrentou resistências e foi redirecionada no processo.

Nesse contexto, o governo do Estado consolidou na saúde um projeto político distinto daquele negociado com a SMS-SP e o Ministério da Saúde, em 2003, no processo de habilitação do município na gestão plena do sistema municipal. Esse movimento pode ser evidenciado tanto na entrevista com o assessor da SES-SP, que apontou a fragilidade do processo de negociação entre a SES-SP e a SMS-SP naquele período, quanto pelo processo de reforma administrativa implementado na SES-SP, entre 2005 e 2006.

É importante considerar, como já discutido por outros autores, que processos similares ao registrado no caso do Município de São Paulo, que implicam em mudanças nas relações de poder no setor saúde, resultam em resistência das SESs e até de governadores, que lutam para manter seu poder de mando sobre serviços ou funções tradicionalmente vinculados ao estado (Oliveira, 2003). Outra questão a ser considerada, nesses conflitos entre gestores municipais e estadual, também pode estar refletindo a falta de definição do papel do gestor estadual no SUS (Levcovitz e col., 2001; Barata e col., 2004). 
Mesmo com identidade político-partidária entre os governos do município e do estado, ainda não foi possível identificar movimento entre esses entes federados no sentido de uma real integração entre a SMS-SP e a SES-SP, no Município de São Paulo. Essa situação se expressou a manutenção de dois subsistemas públicos funcionando em paralelo, um estadual e outro municipal, o que dificulta a incorporação da integralidade da assistência à saúde. Nesse contexto, um dos principais problemas para a gestão do SUS no município, que foi apontado de forma quase consensual pelos distintos atores sociais envolvidos, relacionava-se com a dificuldade de organizar e garantir o acesso a serviços de média complexidade, paradoxalmente, existentes. A manutenção desses dois subsistemas públicos de saúde configura-se em uma fragmentação do SUS, com as conseqüências e ineficiências associadas - atenção descontínua, forte polarização entre hospital e ambulatório e ausência de integração -, como caracterizado e discutido por outros (Mendes, 2001). Nesse contexto, não se pode abstrair a existência de um projeto de "reforma administrativa" do SUS, na agenda pública brasileira, que propõe sua reorganização em dois subsistemas. Um de "entrada e controle", concentrando os serviços da atenção básica, e outro de "referência ambulatorial e hospitalar", concentrando os serviços especializados (Brasil.Mare, 1998), e cujos principais problemas e riscos já foram devidamente discutidos (Almeida, 1999).

\section{Considerações Finais}

É importante destacar que os elementos e evidências do contexto anterior ao SUS mostraram que a integração sanitária, mesmo na sua dimensão intra-setorial da integração de ações e serviços de saúde, continua sendo uma possibilidade concreta a 
alimentar a imagem objetivo da integralidade sistêmica no SUS. Cabe lembrar que a prática de integração de serviços de saúde já foi implementada no país, com distintos matizes, sendo que sua maioria constituiu-se de experiências isoladas ou localizadas (Ramos, 1972; Tanaka e Rosenburg, 1990). No entanto, algumas eram relacionadas com a implementação de programas mais complexos, envolvendo várias instituições, como no caso das AIS e do SUDS (Paim, 1986; Tanaka e col., 1992; Gerschman e Santos, 2006). A própria integração do INAMPS ao Ministério da Saúde e sua, posterior, extinção podem representar uma forma e primeiro exemplo concreto de como se poderia implementar a direção única no SUS, superando a fragmentação do sistema.

Em sentido contrário, a criação e implementação do PAS no Município de São Paulo na década de 1990, mostrou uma nova forma de confrontar a política nacional de saúde e fragmentá-la novamente, reafirmando a autonomia política do município, respaldada no novo federalismo pós-Constituinte. No contexto do novo federalismo brasileiro, a autonomia política de estados e municípios representam um contrapeso à concentração de poder e recursos na União, podendo inclusive vetar a implementação de políticas federais. Um risco desse novo modelo reside no potencial de captura dos governos municipais por interesses privados (Arretche, 2003). Contudo, deve-se considerar esse tipo de risco também existe em relação às outras esferas de governo.

Outra questão estratégica para o futuro do SUS e que este estudo detectou encontrase relacionado com a dinâmica dos hospitais, seu poder e sua grande autonomia em relação ao restante do sistema e que não é uma particularidade do caso de São Paulo. Embora esse tema tenha sido estudado na literatura, seja na área da sociologia das 
instituições, seja na área da gestão de sistemas (Carapinheiro, 1993; Mendes, 2001). Trata-se de um tema importante a ser aprofundado em outros estudos para se buscar caracterizar e compreender melhor essa temática nas grandes cidades.

Nesse sentido, há que se considerar que a incorporação e integração dos hospitais assumem caráter de desafio estratégico para o SUS, pois é muito difícil garantir a integralidade do sistema se a instituição hospital não fizer parte efetiva do sistema. Como já foi discutido por outros, a viabilidade prática do SUS estaria seriamente comprometida caso o poder local não tiver competência legal e técnica para integrar os hospitais ao sistema (Campos, 1992).

No atual contexto histórico e institucional dos hospitais públicos brasileiros e do SUS, cabe uma reflexão sobre os temas da gestão, enquanto função relacionada à organização de sistema, e da gerência, como uma função relacionada com a direção de um serviço ou estabelecimento, nos termos em que foram conceituados na NOB de 1996. Com esse grau de autonomia dos hospitais, historicamente construída, é possível viabilizar a gestão de um sistema municipal e, conseqüentemente de serviços e estabelecimentos de saúde, sem assumir a gerência daqueles considerados estratégicos para o SUS? Assumir apenas a gerência isoladamente parece ser mais fácil, inclusive para projetos de descentralização do SUS.

Por fim, deve-se considerar que implementar uma direção única da saúde no SUS, implica em uma (re)divisão de poder e de recursos. Nesse sentido, pactuar uma direção única constitui-se um problema e um grande desafio políticos e, para viabilizá-la, não bastam normas, nem tampouco instrumentos de gestão. Embora se considere que esses instrumentos sejam necessários, na prática, são insuficientes para a dimensão do problema. A solução parece ser um pouco mais complexa, 
necessitando de abordagens macroestruturais e macropolíticas. Nesse contexto, implementar um processo de negociação, envolvendo os atores institucionais e políticos, visando a (re)pactuação de um projeto político permanente na saúde, se coloca como um desafio estratégico para o SUS.

\section{Referências}

ABRUCIO, F.L. A coordenação federativa no Brasil: a experiência do período FHC e os desafios do governo Lula. Revista de Sociologia e Política, Curitiba, n.24, p.4167, jun. 2005.

ALMEIDA, C.M. Reforma do Estado e reforma de sistemas de saúde: experiências internacionais e tendências de mudança. Ciência \& Saúde Coletiva, Rio de Janeiro, v.4, n.2, p.263-286, 1999.

AROUCA, A. Reforma sanitária brasileira. Tema/Radis, Rio de Janeiro, n.11, p.2-4, 1988.

ARRETCHE, M.T.S. Políticas sociais no Brasil: descentralização em um Estado federativo. Revista Brasileira de Ciências Sociais, São Paulo, v.14, n.40, p.111-141, jun. 1999.

ARRETCHE, M.T.S. Financiamento federal e gestão local de políticas sociais: o difícil equilíbrio entre regulação, responsabilidade e autonomia. Ciência e Saúde Coletiva, Rio de Janeiro, v.8, n.2, p.331-345, 2003.

BARATA, L.C.B.; TANAKA, O.Y.; MENDES, J.V.D. Por um processo de descentralização que consolide os princípios do Sistema Único de Saúde. Epidemiologia e Serviços de Saúde, Brasília, v.13, n.1, p.15-24, 2004.

BARDIN, L. Análise de Conteúdo. $3^{\mathrm{a}}$ ed. Lisboa: Ed. 70, 2004. 229p.

BRASIL. Lei Federal n 8.080, de 19 de setembro de 1990. Dispõe sobre as condições para a promoção, proteção e recuperação da saúde, a organização e o 
funcionamento dos serviços correspondentes. Diário Oficial da União, Brasília, DF, 20 set. 1990. Seção 1, p.18055.

BRASIL. Lei Federal nº 8.689, de 27 de julho de 1993. Dispõe sobre a extinção do Instituto Nacional de Assistência Médica da Previdência Social - INAMPS. Diário Oficial da União, Brasília, DF, 28 jul. 1993. Seção 1, p.10573.

BRASIL. MARE - Ministério da Administração Federal e Reforma do Estado. Reforma Administrativa do Sistema de Saúde. $2^{\mathrm{a}}$ ed. Brasília, DF, Cadernos MARE, n.13, 1998. 43p. Disponível em:

<http://www.bresserpereira.org.br/Reforma_Gerencial_de_1995>. Acesso em: 29 dez. 2008.

CAMPOS, G.W.S. Reforma da Reforma: repensando a saúde. São Paulo: Ed. Hucitec, 1992. 220p.

CARAPINHEIRO, G. Saberes e Poderes no Hospital: uma sociologia dos serviços hospitalares. $2^{a}$ ed. Porto: Ed. Afrontamento, 1993. 196p.

COHN, A.; ELIAS P.E. (Coord.). O Público e o Privado na Saúde: o PAS em São Paulo. São Paulo: Ed. Cortez, 1999. 248p.

COSTA, R.C.R. Descentralização, financiamento e regulação: a reforma do sistema público de saúde no Brasil durante a década de 1990. Revista de Sociologia e Política, Curitiba, n.18, p.49-71, jun, 2002.

GERSCHMAN, S.; SANTOS, M.A.B. O Sistema Único de Saúde como desdobramento das políticas de saúde do século XX. Revista Brasileira de Ciências Sociais, São Paulo, vol.21, n.61, p.177-190, jun. 2006.

LAPASSADE, G. A observação participante. In: . As Microssociologias. Brasília, DF: Liber Livro Ed., 2005. p. 69-90.

LEVCOVITZ, E.; LIMA, L.D.; MACHADO, C.V. Política de saúde nos anos 90: relações intergovernamentais e o papel das Normas Operacionais Básicas. Ciência e Saúde Coletiva, Rio de Janeiro, v.6, n.2, p.269-291, 2001. 
MENDES, E.V. As políticas de saúde no Brasil nos anos 80. In: (Org.).

Distrito Sanitário: o processo social de mudança das práticas sanitárias do Sistema Único de Saúde. São Paulo: Ed. Hucitec, 1993. p.19-91.

MENDES, E.V. A descentralização do sistema de serviços de saúde no Brasil. In: (Org.). A Organização da Saúde no Nível Local. São Paulo: Ed. Hucitec, 1998. p.17-55.

MENDES, E.V. O dilema fragmentação ou integração dos sistemas de serviços de saúde: por sistemas integrados de serviços de saúde. In: Os Grandes

Dilemas do SUS. Salvador: Ed. Casa da Qualidade, 2001. Tomo II, p.71-154.

OLIVEIRA, M.H.C.B. Pactos de gestão: divisão de responsabilidades entre estados e municípios na descentralização. In: PIERANTONI, C.R.; VIANNA, C.M.M. (Org.). Gestão de Sistemas de Saúde. Rio de Janeiro: UERJ/IMS, 2003. p.59-92.

PAIM, J.S. Ações integradas de saúde (AIS): por que não dois passos atrás. Cadernos de Saúde Pública, Rio de Janeiro, v.2, n.2, p.167-183, abr./jun. 1986. PINTO, N.R.S.; TANAKA, O.Y.; SPEDO, S.M. Política de saúde e gestão no processo de (re)construção do SUS em município de grande porte: um estudo de caso de São Paulo (SP), Brasil. Cadernos de Saúde Pública, Rio de Janeiro, v.25, 2009. No prelo.

RAMOS, R. A Integração Sanitária: doutrina e prática. 1972. 366 p. Tese (Livre Docência em Saúde Pública) - Faculdade de Saúde Pública, Universidade de São Paulo, São Paulo.

SÃO PAULO. Decreto n ${ }^{\circ}$ 49.343, de 24 de janeiro de 2005. Dispõe sobre as Coordenadorias da Secretaria da Saúde. Diário Oficial do Estado, São Paulo, SP, 25 jan. 2005.

SÃO PAULO. Decreto $n^{\circ} 51.434$, de 28 de dezembro de 2006. Dispõe sobre a reorganização da Coordenadoria de Serviços de Saúde, da Secretaria da Saúde. Diário Oficial do Estado, São Paulo, SP, 29 dez. 2006. 
SÃO PAULO. SMS - Secretaria Municipal de Saúde. Portaria SMS nº 621, de 23 de janeiro de 2003. Cria 5 Centrais de Regulação Regionais e 1 Central de Regulação Municipal. Diário Oficial do Município, São Paulo, SP, 24 jan. 2003. p.21.

SÃO PAULO. SMS. Portaria SMS n 525, de 13 de agosto de 2004. Institui sistema de regulação e integração para gestão do SUS - Gestão Plena do Sistema Municipal de Saúde. Diário Oficial do Município, São Paulo, SP, 14 ago. 2004. p.22.

SÃO PAULO. SMS. Portaria SMS nº 887, de 29 de junho de 2007. Obriga uso do Sistema de Informação SIGA Saúde. Diário Oficial da Cidade, São Paulo, SP, 30 jun. 2007. p.28.

SÃO PAULO (Município). Conselho Municipal de Saúde. Ata da $78^{a}$ reunião ordinária do Conselho Municipal de Saúde, de 16 de junho de 2005. 19p. Disponível em:

<http://ww2.prefeitura.sp.gov.br//arquivos/secretarias/saude/cms/0019/ata_2005_78_ ord.pdf> Acesso em: 15 out. 2008.

SOBRINHO, E.J.M.A. Saúde em São Paulo, dificuldades e esperanças. In: SOUSA, M.F.; MENDES, A. (Org.). Tempos Radicais da Saúde em São Paulo: a construção do SUS na maior cidade brasileira. São Paulo: Ed. Hucitec, 2003. p.11-15.

SOUZA, R.R. Construindo o SUS: a lógica do financiamento e o progresso da divisão de responsabilidades entre as esferas de governo. In: PIERANTONI, C.R.; VIANNA, C.M.M. (Org.). Gestão de Sistemas de Saúde. Rio de Janeiro: UERJ/IMS, 2003. p.15-58.

TANAKA, O.Y.; ROSENBURG, C.P. Análise da utilização pela clientela de uma unidade ambulatorial da Secretaria da Saúde do Município de São Paulo, SP (Brasil). Revista de Saúde Pública, São Paulo, v.24, n.1, p.60-68, 1990.

TANAKA, O.Y. et al. Gerenciamento do setor saúde na década de 80, no Estado de São Paulo, Brasil. Revista de Saúde Pública, São Paulo, v.26, n.3, p.185-194, 1992. VIANA, A.L.A.; LIMA, L.D.; OLIVEIRA, R.G. Descentralização e federalismo: a política de saúde em novo contexto - lições do caso brasileiro. Ciência e Saúde Coletiva, Rio de Janeiro, v.7, n.3, p.493-507, 2002. 
WALT, G. et al. 'Doing' health policy analysis: methodological and conceptual reflections and challenges. Health Policy and Planning, v.23, p.308-317, 2008.

WEISS, C.H. Evaluation: methods for studying programs and policies. $2^{\text {nd }}$ ed. Upper Saddle River: Prentice Hall, 1998. 372p.

YIN, R.K. Case Study Research: design and methods. $2^{\text {nd }}$ ed. Thousand Oaks: Sage Publications, 1994. 171p. 


\subsection{Artigo 3: formatado visando o periódico Physis}

O artigo “AMA (assistência médica ambulatorial): 'inovação' assistencial ou uma estratégia para 'limpar fila' da porta de prontos-socorros?' foi formatado para ser apresentado aos editores do periódico Physis de Saúde Coletiva, que é uma publicação do Instituto de Medicina Social, da Universidade Estadual do Rio de Janeiro, Rio de Janeiro (RJ).

\section{Referências editoriais do periódico e comunicação autor(es) - editor}

- Artigos

a) Texto e referências - máximo de 20 páginas (incluindo referências, gráficos e tabelas)

b) Referências - em ordem alfabética (ABNT) e citação no manuscrito, entre parêntesis, pelo nome do(s) autor(es) em letras minúsculas

c) Resumo - máximo de 250 palavras

d) Palavras chaves -3 a 6

- Envio do artigo para o periódico

2 de fevereiro de $2009 \rightarrow$ NÃO enviado 


\section{AMA (assistência médica ambulatorial): "inovação" assistencial ou uma estratégia para "limpar fila" de porta de prontos-socorros? ${ }^{3}$}

\section{AMA (ambulatorial medical care): a new health care "innovation" or a “queue cleaner" strategy of gate at emergency health services?}

\section{Nicanor R. S. Pinto}

Médico Sanitarista do Departamento de Medicina Preventiva (Unifesp), Doutorando em Saúde Pública (Faculdade de Saúde Pública da USP), Mestre em Ciências (Unifesp-EPM)

End.: Rua Botucatu 740, Vila Clementino, CEP 04123-062, São Paulo, SP, Brasil

E-mail: nicanor@medprev.epm.br

Tel.: (55-11) 5571-5000

\section{Sandra Maria Spedo}

Médica Sanitarista do Departamento de Medicina Preventiva (Unifesp), Doutoranda em Saúde Pública (Faculdade de Saúde Pública da USP), Mestre em Saúde Coletiva (Unicamp)

End.: Rua Botucatu 740, Vila Clementino, CEP 04123-062, São Paulo, SP, Brasil

E-mail: smspedo@medprev.epm.br

Tel.: (55-11) 5571-5000

\section{Oswaldo Yoshimi Tanaka}

Professor Titular da Faculdade de Saúde Pública (USP)

End.: Av. Dr. Arnaldo 715, Cerqueira César, CEP 01246-904, São Paulo, SP, Brasil E-mail: oytanaka@usp.br

Tel.: (55-11) 3061-7107

\footnotetext{
${ }^{3}$ A pesquisa, que gerou os dados trabalhados neste artigo, teve apoio financeiro do CNPq (Proc.

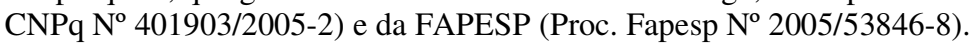




\section{Resumo}

A organização da assistência à demanda de urgência médica é um importante desafio para a gestão local do Sistema Único de Saúde (SUS). Desde 2005, a implantação de serviços denominados AMA (assistência médica ambulatorial) vem sendo assumida como prioridade da política de saúde do município de São Paulo. Foi realizado um estudo de caso, para avaliar o processo de implantação das AMAs, no período 20052008. As fontes de dados foram: entrevistas, documentos e observação participante. O conceito de modelos tecnoassistenciais de saúde foi utilizado como categoria analítica. As AMAs foram organizadas como prontos atendimentos médicos acopladas a estabelecimentos pré-existentes: a maior parte em UBSs; algumas em prontos socorros e ambulatórios de especialidades públicos; e uma minoria em serviços isolados. Embora planejadas inicialmente para 30, em dezembro de 2008 já existiam 114 desses serviços em funcionamento. A motivação política para a priorização do projeto das AMAs era atribuída à baixa resolutividade dos serviços vinculados à Atenção Básica e ao excesso de filas nos prontos socorros públicos da cidade. Discute-se a resistência dos técnicos da atenção primária em saúde (APS) em incorporar a demanda espontânea como uma de suas responsabilidades. Nesse contexto, as AMAs assumiram a condição de marca de governo. Observou-se que, entre usuários, predominava uma avaliação positiva, embora setores mais politizados fossem críticos à proposta. Entre gestores, predominava uma posição pragmática, embora existissem dirigentes críticos a essa política, tanto em relação à necessidade de sua criação, quanto a sua eficiência, como sobre seu potencial de desorganizar a atenção básica.

Palavras chave: Política de Saúde; Gestão em Saúde; Integração de Serviços de Saúde; Sistema Único de Saúde; Modelo Assistencial; Assistência de Urgência 


\begin{abstract}
Organization of health care to the medical urgency demands is an important challenge to the local management of the Brazilian National Health System (SUS). Since 2005, the implementation of services called AMA (ambulatorial medical care) is being assumed as a political priority in São Paulo city. A case study was made to evaluate the process of implementation of the AMA services, during the period from 2005 to 2008. The evidence sources used were: management interviews and documents, and participative observation. The concept of health care model was used as an analytical category. AMAs were organized as emergency rooms together with pre existent health establishments: most of them in basic health unities; some along in emergency rooms services and in secondary care ambulatories; and a few on isolated care services. Although initially planned for 30, on December of 2008 there were already 114 of those services. Political causes for creating AMC as a priority was attributed to the low efficacy of the primary health care (PHC) services and the excessive population queues on the public emergency rooms services. PHC professional resistance to incorporate the population acute and spontaneous demands as one of their routine duties is discussed. On this context, AMCs was established as a government trademark. Among citizen users of SUS, the evaluation was positive, although some were critical. Among public health managers there were a pragmatic position, even though there were some who were critical to this health policy, specialy because its potential to misorganize PHC services.
\end{abstract}

Key words: Health Policy; Health Management; Health Services Integration; Single Health System; Health Care Model; Urgency Care 


\section{Introdução}

A organização da assistência à demanda de urgência médica continua sendo um dos importantes desafios para a gestão local do Sistema Único de Saúde (SUS) em municípios de grande porte, particularmente, em capitais e municípios sede de regiões metropolitanas.

No Brasil, desde a época colonial, a presença do Estado na assistência à saúde teve caráter pontual, com a implantação de ações e serviços em poucas capitais, e dirigida a setores e áreas específicos. Assim, em distintos momentos da história nacional, foram registradas ações como a implantação de hospitais militares, em grandes cidades e vinculada à inexistência de Santas Casas (século XVIII), bem como de hospitais-colônia ou asilos, para doenças específicas como: hanseníase, tuberculose e doenças mentais (séculos XIX e XX). Os primeiros registros de "serviços de assistência pública destinados a socorros médicos de urgência desenvolvidos sob jurisdição municipal” são datados do final do século XIX e início do século XX (Guimarães, 1982, p.107).

No período entre final do século XIX e a primeira metade do século XX, com o desenvolvimento econômico e industrial, o país experimentou uma aceleração em seu processo de urbanização e transitou de um modo de produção, predominantemente, escravista e agroexportador para um modo de produção capitalista, urbano e industrial (Pereira, 1984). Essa mudança no padrão da economia foi a base sobre a qual se formou uma nova classe de trabalhadores urbanos assalariados, para a qual o sistema previdenciário e o subsistema de saúde previdenciária era dirigido e se desenvolveu (Oliveira e Teixeira, 1989). 
Nesse contexto histórico e institucional, a Lei Federal nº 6.229 de 1975, já revogada, instituiu o sistema nacional de saúde brasileiro, consolidando a fragmentação de ações e serviços de saúde, até então, existentes. Essa lei estabelecia as responsabilidades das três esferas de governo - federal (incluindo todos os ministérios que atuavam na saúde: previdência, saúde, educação, interior, forças armadas, justiça), estadual e municipal -; cabia aos municípios a responsabilidade pela assistência das urgências e emergências. Esse sistema de saúde, assim configurado, fragmentado e segmentado, vigorou até o início do processo que instituiu o SUS (Guimarães, 1982; Gerschman e Santos, 2006).

Entre as décadas de 1970 e de 1980, o Município de São Paulo, para cumprir essas responsabilidades legais, contava com uma rede de: 13 hospitais próprios, com serviços de emergência vinculados; alguns serviços caracterizados como prontos socorros isolados, com sala de emergência e poucos leitos de observação de curta duração, mas sem leitos e sem centro cirúrgico; e cerca 40 unidades ambulatoriais, denominadas à época de postos de assistência médica (PAMs). Esses serviços desenvolviam ações preferencialmente para as áreas de: puericultura; pré-natal; e atendimento de quadros ou problemas agudos, na forma de serviço de pronto atendimento (PA). Além dessa rede própria, o município financiava alguns hospitais privados filantrópicos, para que estes atendessem a população sem vínculo empregatício formal - não segurada pela Previdência Social - em seus serviços de urgência e emergência, bem como em alguns leitos hospitalares.

O período de 1983 a 1985 marcou o início da redemocratização do país e, a partir da eleição direta de um governador do partido do movimento democrático brasileiro (PMDB) para o governo do estado, este nomeou Mário Covas, do mesmo partido, 
como prefeito da capital. Nessa gestão, a secretaria municipal de saúde (SMS-SP) teve a sua frente um médico sanitarista, militante do ideário da reforma sanitária e do SUS (Alves e col., S.D.). Nessa gestão, a saúde foi priorizada e conseguiu fazer um dos primeiros processos de municipalização do país, envolvendo cerca de 80 unidades básicas de saúde (UBSs) recém construídas por um programa estadual, o programa metropolitano de saúde. O desafio da gestão foi incorporar e ampliar, na rotina de suas UBSs, ações de assistência médico-sanitária, também denominadas por alguns de ações programáticas. Até então, essas ações eram desenvolvidas principalmente nos centros de saúde estaduais.

Entre 1985 e 1988, o Município de São Paulo foi governado pelo prefeito Jânio Quadros, que era vinculado ao partido trabalhista brasileiro (PTB). Esta gestão municipal não priorizou a saúde, nem tampouco imprimiu uma marca política da gestão na saúde. Nesse período, a SMS-SP manteve a rede pública municipal em estado inercial. Se por um lado, não foram implementadas mudanças significativas no modelo assistencial, por outro, tampouco foram repostos as perdas - por mortes, aposentadorias ou demissões - de trabalhadores da saúde.

Na gestão municipal 1989-1992, governada pela prefeita Luiza Erundina do partido dos trabalhadores (PT), a SMS-SP foi dirigida por dois médicos sanitaristas, também militantes da reforma sanitária e do SUS, que conduziram um processo de reorganização institucional e a descentralização intramunicipal da saúde, com a criação de 31 Distritos de Saúde. Estes foram organizados e implementados tendo como referência o modelo assistencial da vigilância em saúde, de forma articulada com a manutenção de ações programáticas e com a incorporação de equipes multiprofissionais (Furtado e Tanaka, 1998). 
Entre 1993 e 1996, o Município de São Paulo teve Paulo Maluf como prefeito, que era do antigo partido da democracia social (PDS). Essa gestão marcou a saúde pública e o município por ter criado e implementado um dos mais polêmicos projetos contra o SUS experimentado no país, o Plano de Atendimento à Saúde (PAS). A implantação do PAS, além de desorganizar a estrutura da SMS-SP, no plano da gestão, organizou a primeira experiência gerencialista de um sistema local em município de grande porte do país, transferindo a gestão de 14 módulos assistenciais para cooperativas de profissionais de saúde criadas para esse fim. No plano assistencial, as UBSs funcionavam predominantemente no modelo de pronto atendimento, centrado no trabalho médico (Keinert, 1997; Cohn e Elias, 1999). Essa gestão teve forte apelo popular e conseguiu eleger seu sucessor, Celso Pitta, que foi prefeito do município de 1997 a 2000, dando continuidade ao PAS até o fim de seu mandato.

A gestão 2001-2004 teve uma nova prefeita do PT, Marta Suplicy, que marcou sua gestão na saúde com a extinção do PAS e o alinhamento da política municipal de saúde com o SUS. Nesse período, a SMS-SP foi, novamente, dirigida por dois médicos sanitaristas que priorizaram, além da desmontagem do PAS, a incorporação do Município de São Paulo ao SUS, a retomada do modelo assistencial da vigilância em saúde, de forma combinada com ações programáticas, a implementação de novo processo de distritalização da SMS-SP e a implantação do Programa de Saúde da Família (PSF) como projetos prioritários. Nessa gestão, também se registrou a municipalização dos CSs estaduais e a habilitação do município na condição de gestão plena do sistema municipal de saúde. 
No período da gestão 2005-2008, o governo foi conduzido por uma frente partidária, composta pelo partido da social democracia brasileira (PSDB), que teve o prefeito José Serra na primeira metade do mandato, e pelo partido democrático brasileiro (DEM), cujo vice Gilberto Kassab assumiu a prefeitura na segunda metade do mandato, quando o prefeito foi eleito para o governo do estado. Nessa gestão, a SMS-SP teve quatro secretários a sua frente, sendo que a maioria tinha pouco acúmulo profissional e político-institucional com o SUS. Para enfrentar o problema das filas nos serviços de urgência e emergência da cidade, a SMS-SP priorizou a implantação de um modelo assistencial centrado no pronto atendimento, em unidades denominadas Assistência Médica Ambulatorial (AMA). Esse projeto das AMAs, em particular, foi usado como uma das marcas políticas da gestão na campanha eleitoral, que reelegeu Kassab prefeito que, por sua vez, se comprometeu publicamente a expandi-las ainda mais, em seu novo mandato.

A implantação das unidades de AMA foi assumida como prioridade da política municipal de saúde, desde o início da gestão 2005-2008. As AMAs foram organizadas dentro de estabelecimentos pré-existentes, em sua maioria Unidades Básicas de Saúde (UBSs), com o objetivo de "ampliar o acesso de pacientes que necessitam de atendimento imediato, racionalizar, organizar e estabelecer o fluxo de pacientes para as UBS, Ambulatórios de Especialidades e Hospitais" (São Paulo.SMS, 2008).

Nesse contexto, este artigo teve o objetivo de avaliar o processo de implantação do projeto de unidades de AMA e, na medida em que a maioria delas foi acoplada a UBSs pré-existentes, discutir essa integração de serviços de saúde na lógica da integralidade do SUS, no Município de São Paulo, no período da gestão 2005-2008. 


\section{Métodos}

O delineamento do estudo foi fundamentado na pesquisa avaliativa, em sua dimensão adotada de análise de implantação, que tem como base um projeto de intervenção em um dado contexto organizacional. No plano teórico, há uma analogia entre o modelo político adotado neste estudo, com um jogo de poder organizacional, sendo seu resultado associado mais aos interesses dos distintos atores presentes e em disputa do que a seu próprio planejamento (Denis e Champagne, 1997; Draibe, 2001).

A estratégia metodológica adotada foi a de um "estudo de caso", que se caracteriza por ser uma investigação sobre um fenômeno contemporâneo e complexo, realizada em seu contexto. Outra característica dessa estratégia é que não há definição nítida das fronteiras entre o fenômeno estudado e seu contexto (Yin, 1994).

O conceito de "integração sanitária", em sua dimensão intra-setorial, foi escolhido como categoria analítica. Esse conceito diz respeito a ações e serviços do setor saúde e consiste em "agrupar órgãos díspares dentro de um plano e um programa de ação comuns; e reuní-los em um serviço que funcione como um todo harmônico sob uma chefia única” (Ramos, 1972, p. 6). Destaca-se que há afinidade conceitual entre este e o princípio da integralidade do SUS, expresso no artigo $7^{\circ}$, inciso II da Lei ${ }^{\circ} 8.080$ (Brasil.MS, 1990).

Utilizou-se, também, o conceito de "modelos tecnoassistenciais de saúde" como outra categoria analítica de forma articulada. Esse conceito é associado à formação da Saúde Pública como política governamental, considerando que se deve tomar a “dimensão assistencial como central, sem desconsiderar a dimensão tecnológica, pois é através da primeira que se pode captar as questões referentes à forma de organização da produção dos serviços e à sua concretização enquanto instituições 
específicas. A configuração dessas ações de saúde, enquanto política governamental, adquire o formato de modelos tecno-assistenciais para as formulações que procuram apresentá-los como projetos de políticas públicas que disputam determinados rumos possíveis para as políticas governamentais, no campo da saúde coletiva" (Merhy, 1992, p.17). Considerado sob outra perspectiva, esse conceito poderia ser expresso também como: "forma ou modo de produção de serviços de saúde seria uma composição concreta de recursos (financeiros, materiais e força de trabalho), tecnologias e modalidades de atenção, articulados de maneira a constituir uma dada estrutura produtiva e um certo discurso, projetos e políticas que assegurassem a sua reprodução social” (Campos, 1992, p.38).

Foram utilizadas as seguintes fontes de evidência: (a) atores sociais e institucionais do processo de gestão ("informantes-chaves"), selecionados entre o corpo dirigente da gestão municipal da saúde, por meio entrevistas; (b) documentos da gestão; e (c) observação participante.

As entrevistas realizadas eram não-estruturadas, conduzidas pelos próprios autores, gravadas e transcritas. Os objetivos gerais da pesquisa eram apresentados ao entrevistado, que era estimulado a discorrer sobre o tema central, livremente, após o que os autores exploravam temas de interesse específico.

Os documentos de gestão analisados foram: documentos oficiais (decretos, portarias, relatórios de conferências, atas de reuniões, folder de divulgação) publicados ou disponibilizados em: Diários Oficiais; sítios institucionais; documentos internos, mesmo que em versões preliminares; e publicações de sujeitos da pesquisa.

A observação participante foi desenvolvida, com implicação de tipo "periférico" (Lapassade, 2005), por dois dos autores em reuniões plenárias do Conselho 
Municipal de Saúde, em Conferências Municipais de Saúde, em visitas a serviços e estabelecimentos de saúde da SMS-SP e em conversas com gestores, técnicos da gestão e cidadãos-usuários. Neste artigo, as informações obtidas por essa técnica foram usadas como fonte primária de evidência, com a reprodução de frases curtas no texto, e como fonte secundária de evidência, para uma triangulação de fontes e técnicas.

Considerando os objetivos do artigo e a dimensão territorial do município, optou-se por delimitar este estudo a uma única instância administrativa regional da Secretaria Municipal de Saúde de São Paulo (SMS-SP). Na gestão 2005-08, a SMS-SP era composta por 5 Coordenadorias Regionais de Saúde (CRSs) e 24 Supervisões Técnicas de Saúde (STSs). A região selecionada foi a de uma STS, denominada aqui de STSe, que abrange uma Subprefeitura, com três Distritos Administrativos e uma população residente estimada em torno de 430 mil habitantes. Neste artigo, para preservar o anonimato dos dirigentes entrevistados, foram utilizadas as siglas CRSe e STSe para identificar as instâncias regionais selecionada e CRSc para identificar outra regional, cujo coordenador foi convidado a participar. No sentido de se preservar a identidade dos dirigentes entrevistados, as seleções reproduzidas foram identificadas pela função pública exercida por seu autor.

O material selecionado foi analisado com referência na técnica da análise temática (Bardin, 2004). Para tanto, foram identificados temas sobre o processo de delineamento do projeto e da implantação das unidades AMA no município de São Paulo, pela SMS-SP, baseados em dois critérios: destaque no discurso dos dirigentes entrevistados ou em documentos de gestão e concordância de escolha entre os autores. 
Este artigo analisou dados coletados em pesquisa, cujo projeto inicial foi submetido e aprovado pelos Comitês de Ética em Pesquisa da Faculdade de Saúde Pública (USP) e da Secretaria Municipal de Saúde de São Paulo, com base na Resolução n 196/96 do Conselho Nacional de Saúde.

\section{Resultados}

As AMAs caracterizavam-se por serem serviços planejados para atenderem patologias de baixa e média complexidade, sem agendamento prévio, contando com apoio radiológico, de alguns exames de patologia clínica e de ambulância para remoção de casos graves.

Desde o início do processo de sua implantação, a gestão das AMAs era apresentada como sendo compartilhada entre a Secretaria Municipal de Saúde e instituições parceiras, cabendo a estas a adequação da estrutura física e a contratação de pessoal. Sua implantação teve início em março de 2005 e, em que pese um planejamento inicial de apenas 30 AMAs (PPA 2006-2009), no início de dezembro de 2008, a SMS-SP divulgava a existência 114 unidades em funcionamento (Figura.1). Desse total, $88(77,2 \%)$ estavam instaladas acopladas a UBSs, $10(8,8 \%)$ estavam em ambulatórios de especialidades, 8 (7,0\%) estavam em prontos-socorros de hospitais municipais e outras $8(7,0 \%)$ estavam funcionando de forma isoladas, em prédios alugados, geralmente próximos a grandes hospitais de referência do SUS.

Os principais achados foram classificados em três temas eixo: o contexto da Atenção Básica; o projeto das unidades de AMA; e o processo de implementação do projeto das AMAs. No primeiro tema eixo, foram identificados três núcleos temáticos: motivação, origem política, baixa resolutividade da atenção básica e filas nos 
prontos-socorros públicos. No segundo eixo, três núcleos temáticos: concepção, projeto e "imagem objetivo". E, no terceiro eixo, foram identificados outros três núcleos: poder, atores e localização.

Figura 1. Evolução do número de unidades de AMA (Assistência Médica Ambulatorial), por ano-calendário. São Paulo (SP): 2005 a 2008.

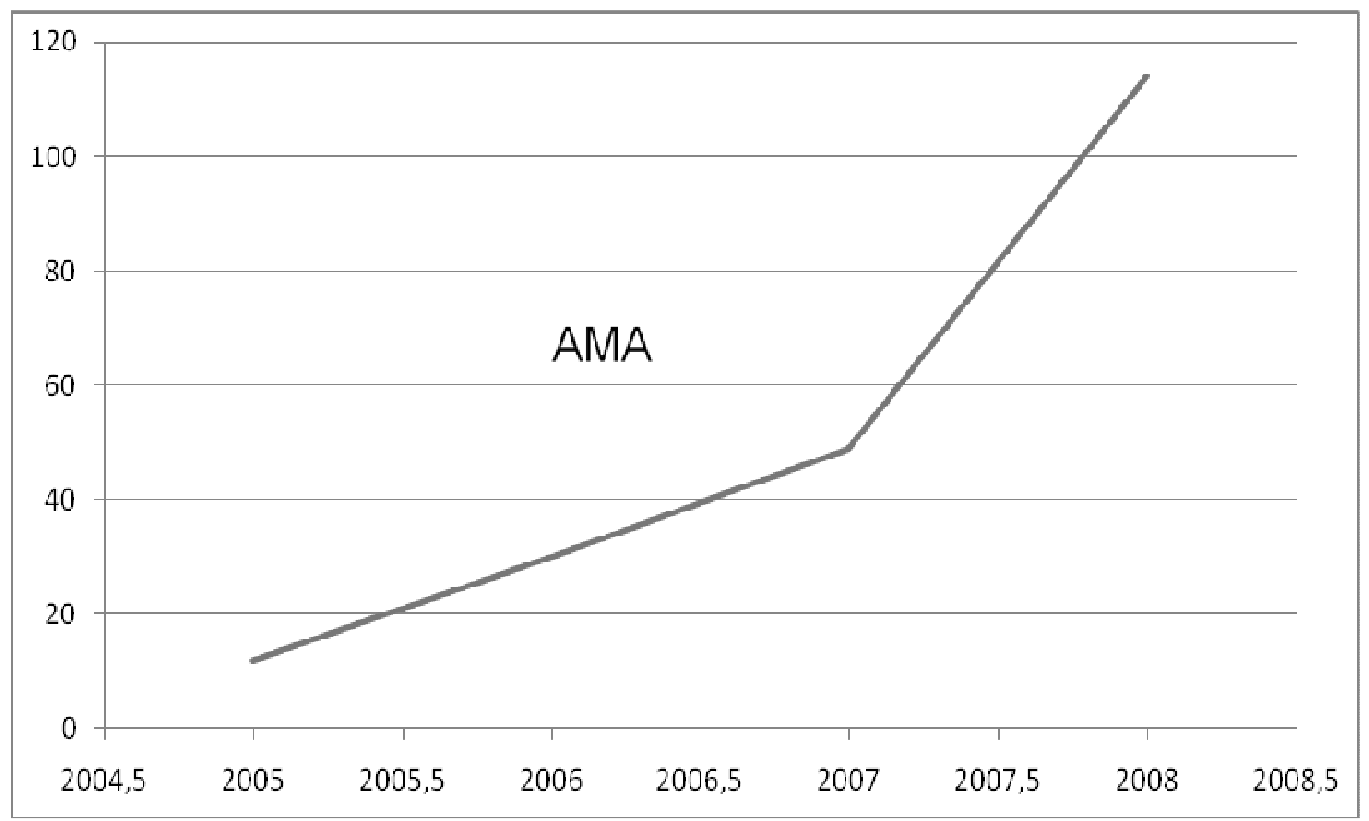

Fonte: Ceinfo (SMS-SP, dez. 2008).

\section{- O contexto da Atenção Básica}

No contexto da prática dos serviços de Atenção Básica e em sua relação com os cidadãos-usuários do SUS, pode-se avaliar como alguns profissionais vinculados a esses serviços vêm lidando com essa demanda para eventos agudos ou não programados, também denominados de "demanda eventual" ou ainda "demanda espontânea". Reproduzimos algumas das respostas dirigidas a alguns cidadãosusuários ou pacientes do serviço por trabalhadores da saúde vinculados em distintos 
serviços (UBS “tradicional” ou UBS com PSF), na maioria das vezes em espaços públicos e abertos (recepção, sala de vacina, farmácia), na presença de um dos autores, e que puderam registradas:

"Aqui [UBS ou PSF] é o lugar da saúde!"

"O lugar da doença é o hospital!"

"O lugar da doença é o pronto socorro!”

"Hoje não dá pra passar. Hoje é dia só de pré-natal”

"Você chegou atrasada! [20 min.!!] Vai ter que remarcar!"

"Quando o investimento, a cobertura de PSF for maior na cidade, vão acabar as filas dos prontos-socorros”.

Em relação ao projeto das unidades de Assistência Médica Ambulatorial (AMA), um primeiro aspecto a ser abordado relaciona-se com sua motivação e concepção. Nesse sentido, uma informação sobre as motivações e primeiras idealizações desse projeto remete à relevância política que a saúde vem assumindo para a política municipal e o papel do próprio prefeito na identificação de uma potencial solução para problemas da área, como se pode evidenciar no relato do gestor abaixo:

“Temos AMAs acopladas à Atenção Básica, [...] aliás, a idéia surgiu em um tipo de unidade existente no Jardim Angela, onde estava 100\% implantado o PSF. [...] O prefeito entendeu que aquela unidade de nível primário dava suporte e sustentabilidade para o PSF. Fazia até vasectomia! Uma unidade do nível primário, que atendia pequenas urgências, aliviando a demanda $e$ aliviando as filas. [...] Na época, o prefeito visitou, achou interessante e resolveu: um tipo de unidade como aquela, em outras regiões. [...] Tem raio-X, 
né? [...] Para dar alguma resolutividade para as UBSs. Assim, surgiu a AMA!" (gestor E).

Outro motivo alegado para que a SMS-SP implementasse esse novo projeto, foi relacionado por outro gestor como sendo a fragilidade da Atenção Básica, tanto por falta de profissionais, quanto por uma baixa resolutividade. E, caracterizou o perfil do novo programa de unidades que, à época, ainda sem uma "marca" ou um "nome fantasia", eram identificadas como unidades de pronto atendimento, como manifestou o gestor do período ao Conselho Municipal de Saúde:

“A Atenção Básica está com uma rede totalmente incompleta e precisamos tomar algumas medidas imediatas. A primeira coisa que pensamos fazer foi colocar nas Unidades Básicas o Pronto-Atendimento, porque a agenda hoje com poucos médicos não comporta mais o atendimento da demanda que a população precisa. Por isso vocês viram anunciados aí as 30 Unidades Básicas escolhidas pra que a gente possa de imediato começar o Pronto-Atendimento junto com elas, formando equipes de 2 pediatras, 2 clínicos, 1 cirurgião, mais equipe de enfermagem adequada para que possa atender a não agenda que virá das Unidades naquele dia, naquele momento, doze horas por dia, das 7 as 19 hs, de segunda a sábado. Pretendemos fazer esse tipo de atuação, fortalecendo a Atenção Básica. [...] Estaríamos escolhendo algumas Unidades que já tem estrutura física para não precisar de muita reforma e readequação e nelas estaríamos colocando também o Pronto-Atendimento. [...] Com relação as Unidades Básicas, nós não estaremos abrindo a Unidade toda aos sábados, vamos abrir só a Unidade de Pronto-Atendimento. Essas trinta Unidades escolhidas, agora já foram mapeadas” (São Paulo.CMS, 2005, p.8-12). 
Essa motivação aparece de outra forma na percepção de um dirigente do nível central da SMS-SP, mas que reforça a dimensão política da saúde na avaliação dos governantes:

“Na verdade, o que pressiona um político? É a fila do pronto-socorro! [...] Pronto-socorro cheio, paciente na maca, é isso que é explorado [pela imprensa]. [...] Quem tem decisão política, quer resolver esse problema!” (assessor do gabinete-1 - SMS-SP).

Contudo, a solução encontrada pelo prefeito, para parte dos problemas da saúde, não foi compartilhada por parte importante da equipe de gestão da saúde, como explicitado pelo gestor do período:

“Estão começando a aparecer as críticas às AMAs, porque não resolve! No fundo, cria novos focos de demanda! Novas 'represas'! Você só mudou a represa. Tira uma parte do pronto-socorro, tira uma parte da unidade básica e joga para um negócio chamado AMA, que não é nem pronto-socorro e nem unidade básica. É um atendimento sob a forma de um PA! [...] Isso, necessariamente, teria que ser feito através da criação das AMAs? Eu acho que não. A gente precisava de unidades básicas de saúde um pouco melhores. [...] Discordava de ter isso como marca governamental. [...] A AMA, pra mim, é uma marca. Ela agrega? Pode ser. [...] A AMA é uma parte que foi valorizada dentro de um particular, marginalizando-se a importância do todo! [...] Somos técnicos! Adiantou alguma coisa a criação das AMAs? Resolveu o problema da saúde em São Paulo? Nada! 'Agora, tem uma porta de entrada'. O que acontece? Você saiu de lá com um pedido de exame. Vai fazer o que? Vai para onde?” (gestor C). 


\section{- O projeto das unidades de AMA}

Alguns dirigentes identificaram, no projeto das unidades AMAs, uma nova "porta de entrada" do sistema de saúde, embora alternativa. Na medida em que tinha a possibilidade de ampliar o acesso de cidadãos/usuários ao sistema de saúde.

“As AMAs tinham a proposta de levar o usuário para dentro da UBS. [...] Porque, hoje, ele não está na UBS. [...] Não está acreditando na UBS, porque não tem resolutividade lá” (assessor do gabinete-1 - SMS-SP).

“A AMA é um serviço que está no nível da Atenção Básica! Não está no nível secundário. [É] atendimento da demanda espontânea. [...] Ele vem aumentar o acesso à Atenção Básica!” (assessor do gabinete-2 - SMS-SP).

Em função da baixa resolutividade da Atenção Básica, tanto nas UBSs de "modelo PSF", como nas de "modelo tradicional", a AMA era preconcebida como tendo uma vantagem sobre ambas. E essa vantagem era claramente identificada com o fato de que esses serviços eram programados para dispor de equipamentos de raio- $\mathrm{X}$ e de acesso diferenciado e agilizado a exames laboratoriais. Dessa forma, a AMA era avaliada como tendo potencial de aumentar a resolutividade da Atenção Básica.

“A UBS tem muito pouco recurso para resolver os problemas. [...] Um dos grandes males da Atenção Básica é a falta de resolução de problemas, que chegam na unidade. [...] A AMA vem com aquela idéia de poder atender na hora, se a pessoa tem um evento agudo, e poder resolver o evento agudo. Não basta atender!” (coordenador da CRSc).

“A proposta do AMA [...] traz também uma melhoria: um aumento da resolutividade da unidade. Ela ganha um raio-X, ela ganha alguns equipamentos. Ela ganha uma sala de observação mais equipada, uma sala de 
emergência mais estruturada, com respirador. [...] Ela vem completar, uma coisa complementar de uma unidade básica” (supervisor da STSe).

Observou-se que alguns dirigentes da SMS-SP tinham uma percepção da AMA, seguindo o material de divulgação da Secretaria, como mero atendimento médico ambulatorial ofertado para situações e eventos agudos que, de acordo com os mesmos, não vinham sendo atendidos ou resolvidos nas unidades básicas de saúde (UBSs).

"O AMA [...] é colocado como Atendimento Médico Ambulatorial. Ele vem cobrir [...] aquele paciente que chega hoje em uma unidade básica e vai ser agendado para daqui a um/dois meses. Uma consulta com um clínico; não uma consulta de especialidades. A proposta do AMA é que haja um médico ali, na unidade, que esteja apto a dar um atendimento e uma orientação, naquele momento" (supervisor da STSe).

“A AMA vem preenchendo uma brecha que a gente não conseguia preencher, que é antiga, que é como a gente atende o evento agudo nas unidades básicas. Faz parte da integralidade também!" (coordenador da CRSc).

Alguns dirigentes já conseguiam perceber que esse projeto estava ganhando um certo status e que se podia considerá-lo como uma estratégia da instituição para a organização dos serviços de saúde vinculados à SMS-SP, no município. Contudo, o caráter e identidade da AMA como um serviço de pronto-atendimento gerava algumas divergências ou incômodos.

“A AMA é uma estratégia! A AMA não é um PA [pronto atendimento], como muitas pessoas pensam! A AMA vai atender aquela demanda da busca do dia da 
unidade de saúde. [...] Você otimiza o espaço físico e oferece consulta. E, ela tem uma certa resolutividade” (coordenador da CRSe).

Outra concepção sobre o projeto das AMAs, que tiveram certa centralidade nos discursos de alguns dirigentes da SMS-SP, relaciona-se com o fato desse serviço poder ser uma solução ou, pelo menos, ter potencial para diminuir as "filas de prontos-socorros públicos" - um problema recorrente para os gestores da saúde -, como se evidenciou nos trechos destacados:

"Ela [a AMA] tira da porta do pronto-socorro! Ela deixa para o prontosocorro espaço para a própria emergência, para a verdadeira emergência” (coordenador da CRSe).

“Com a AMA, aquele usuário que precisava de um pronto atendimento, mas está indo na porta de um do pronto-socorro, ele seria atendido dentro de uma UBS. [...] A proposta era aliviar um pouco a porta do pronto-socorro" (assessor do gabinete-1 - SMS-SP).

\section{- O processo de implementação do projeto das AMAs}

Embora a proposta inicial fosse implantar esses serviços, predominantemente, de forma acoplada às UBSs, destacou-se a informação de um gestor do período, que registrou a implantação do serviço em prontos-socorros. Esse mesmo gestor, ainda, forneceu um dado de pesquisa encomendada pela SMS-SP junto aos usuários, para aferir o grau de satisfação, como reproduzido abaixo:

"Ao observarmos que [a AMA] reduziu a demanda nos pronto-socorros desse tipo de necessidade, pronto! Pensou-se em uma AMA que ficasse acoplada ao pronto-socorro atendesse a pequena urgência. [...] A primeira, foi colocada junto ao hospital T; atende $75 \%$ da demanda! Somente o restante entra para 
dentro do hospital. [...] Acoplada a pronto-socorro, só tem no [hospital] T, no CL e no Z. [...] A experiência é muito interessante. Em pesquisa de satisfação dos usuários, 95\% estão satisfeitos com o atendimento” (gestor E).

O projeto das AMAs foi concebido, elaborado e implementado de forma centralizada, incorporando pouco debate ou sugestões dos níveis regionais da SMSSP. Os dirigentes, com atuação em instâncias de gestão locorregionais, foram incumbidos de encaminhar e acompanhar o processo de implantação das AMAs junto com a instituição "parceira", que também era definida e contratada centralmente. $\mathrm{O}$ relato do supervisor evidencia que o mesmo não participou sequer da definição da localização geográfica do serviço planejado para a STS sob sua responsabilidade.

“Eu fui informado que [a UBS] VM seria o segundo AMA nosso aqui da região. [O "parceiro"] seria o hospital R. Depois voltou, vai, volta, tudo. Ele acabou sendo cancelado pela Secretaria. Vocês devem estar pensando: 'E qual a participação que você teve nisso?' 'Nenhuma! Nenhuma!' Fui informado: 'Olha, o AMA da VM não sai mais!' 'Ah, mas por quê?' 'Não, não sai mais! Preferimos. Não sai mais!' [...] Então se decidiu que meu segundo AMA, na região, seria o [pronto-socorro] AGM. Aí, eu falei: 'O AGM?! Muito bem, essa unidade não é minha!' O AGM pertence a uma autarquia [hospitalar], antiga autarquia J. [...] A orientação: 'Você não faz nada. A autarquia vai providenciar o AMA' [...] O AGM, para quem não conhece é um prontosocorro, sem unidade hospitalar acoplada, sem internação! O que faz um AMA dentro de um pronto-socorro? Será que essas coisas não se sobrepõem?[...] 'É uma decisão. Esqueça o VM! Seu segundo AMA vai ser no AGM!' Eu cumpri as 
ordens! Esqueci o VM e estamos esperando o AGM como AMA” (supervisor da STSe).

Ao mesmo tempo em que esse dirigente se considera sem poder para interferir nesse processo, um ator social se destacou atuando, no sentido de alterar o projeto inicial da AMA planejado pela SMS-SP: o movimento popular de saúde da região. No entanto, essa interferência não se deu na concepção do projeto, mas em alguns aspectos mais periféricos como, por exemplo, na definição da UBS em que a AMA iria ser implantada. O Conselho Gestor de uma UBS da região, ao tomar conhecimento que sua unidade havia sido escolhida para sediar a implantação de uma AMA, atuou resistindo a essa iniciativa da Secretaria e impedindo a implantação, pelo menos por algum tempo, conforme relatado no trecho reproduzido: “A UBS JSS seria uma proposta para um outro AMA, por estar distante, por estar bem na pontinha da região. [...] É uma unidade que facilmente se transformaria em um AMA, porque não exige construção, ela é grande, ela tem uma estrutura boa. [...] O Conselho de Gestão da unidade recusou o AMA. Ele fez uma recusa inicial. [...] No momento em que foi oferecido para o Conselho, a proposta era muito desconhecida, vamos dizer assim. Ninguém sabia o que era. Era um 'bicho papão': vai acabar com os funcionários, vai tirar todo mundo de lá, o médico bonzinho que eles gostam vai sair de lá. Hoje, acho que já desmistificou essa questão. [...] Acredito que hoje eu consiga conversar com essa comunidade para propor a implantação de um outro AMA. [...] No momento em que eu tiver com o Conselho a favor, se é que eu vá conseguir isso, eu vou trazer a Coordenação para estar vendo a possibilidade disso. É um funil, eu falo: 'Olha, a comunidade aceita o AMA lá. Vamos fazer?' Daí, eu vou ter 
que esperar eles dizerem: 'Olha, seu 'parceiro' é fulano! Você faz em tal lugar. Tem que fazer até tal data!'” (supervisor da STSe).

A participação ativa do ator social "movimento popular" também contribuiu para alterar o projeto inicial, planejado no nível central da SMS-SP, modificando a proposta de horário de funcionamento de uma AMA implantada na região. A unidade de AMA em foco, que pela proposta inicial da instituição funcionaria 12 horas por dia, de segundas a sextas-feiras, teve seu horário de funcionamento estendido para 24 horas diárias, incluindo os sábados e os domingos, a partir de mobilização e pressão política do movimento popular diretamente com o prefeito, como foi relatado na entrevista:

“A [Associação de Moradores U], que é uma organização interna deles ali, foi para o prefeito e fez uma bela de uma queixa: 'Vocês vão fechar o nosso atendimento noturno? Não, não vão não!' Aí, o AMA se tornou 24 horas. Mas, sem fim de semana. Voltei a uma reunião do Conselho: 'Mas, e o fim de semana?' 'Não, não tem fim de semana'. Voltei para a Coordenação: 'Então, vamos estender até sábado'. Enfim, uma semana antes da inauguração, se abriu o 'plantão de domingo'. E, com isso, ficou a semana inteira. Foi esse trâmite, de negociação difícil com a coordenação. Eu, supervisor. A comunidade me cobrando. [...] Na verdade, o que quebrou o elo foi a hora em que o prefeito foi lá, visitar. E, a comunidade pegou o prefeito! Eu tenho claro isso. O prefeito chegou e falou: 'Não. Vai ser noturno!' E, aí, virou noturno” (supervisor da STSe).

Outro ator que se destacou, interferindo em alguns aspectos do projeto da AMA, foi o 'parceiro'. Geralmente, referido como a 'parceira', essa era uma instituição 
contratada pela SMS-SP, regida pelo direito privado, que compartilhava com esta a gestão das equipes do PSF e, desde 2005, também das AMAs. As instituições 'parceiras' tinham algum poder e relativa autonomia para interferir nas escolhas de serviços nos quais as AMAs seria implantadas podendo, inclusive, não aceitar a proposta oficial, como pode ser evidenciado pelo trecho reproduzido:

"A idéia era fazer uma AMA por Supervisão [STS]. Eu escolhi um lugar no C, um lugar na LP, um lugar no B. Isso foi e voltou. No fim, nenhum dos três lugares deu certo para fazer a AMA! [...] Eu tenho uma região ruim, que é a região da $R$. [...] Mas lá, com essa intervenção da universidade, a coisa está muito melhor. Como a universidade voltou e não tinha interesse, para o ensino, ter uma AMA junto com o PSF. Foi meio que desqualificado! Então, eles propuseram um outro lugar" (coordenador da CRSc).

\section{Discussão}

Neste artigo, julga-se importante discutir as questões desse tema mais relacionados com suas dimensões técnicas e políticas do modelo priorizado. E, ainda, o quanto ele pode conviver com os modelos tradicionais de UBSs ou mesmo aqueles serviços organizados sob um suposto novo paradigma, que hoje, no Brasil, estão concentrados nas equipes de PSF.

Pelo que se pode evidenciar, seja nos discursos dos atores institucionais, seja na evolução numérica registrada no processo de implantação das AMAs, esse serviço, independentemente, de quaisquer objeções técnicas ou econômicas parece ter respondido a parte da demanda por serviços de pronto atendimento na cidade. Os dirigentes, com papel e poder na gestão, deixaram claro um tipo de motivação de 
caráter mais técnico quando destacaram, em sua análise, a questão da baixa resolutividade da Atenção Básica e o excesso de fila nos poucos prontos-socorros públicos.

Dessa forma, é importante reconhecer que o problema da falta de resolutividade da Atenção Básica existe, assim como as filas nos prontos socorros-públicos. A Atenção Básica, inclusive o PSF do município, apresentam indícios de baixa resolutividade e baixa acessibilidade, seja por questões relacionadas à formação e à alta rotatividade dos profissionais, particularmente, dos médicos, seja por falta de uma gestão local mais consistente.

Esse problema é agravado por uma postura ideológica desses profissionais que abstraem essa necessidade de realizar um atendimento médico imediato, atribuindo à população uma suposta ignorância sobre o papel da Atenção Básica ou da Atenção Primária em Saúde (APS). Por outro lado, é importante reconhecer que, se as demandas ou problemas agudos não são atendidos prontamente e próximo ao local de moradia, as portas dos poucos e precários prontos-socorros públicos do município fiquem cada vez mais cheios e com filas cada vez maiores.

Deve-se considerar que, desde a conferência de Alma-Ata, a concepção de Atenção Primária de Saúde mais bem divulgada se associa à dezena de pontos relacionados com a Declaração da conferência, mas omitem-se ou abstraem-se dois conteúdos fundamentais. Um que caracteriza a APS como "o primeiro nível de contato dos indivíduos, das famílias e da comunidade com o sistema de saúde, levando o cuidado à saúde o mais próximo do lugar onde residem e trabalham as pessoas”. E outro, na mesma página, que detalha a abrangência da APS, compreendendo inclusive "o tratamento apropriado das enfermidades e traumatismos comuns” (OMS, 1978, p. 
4). Nesse sentido, em uma cidade como São Paulo, que por suas características sócio-demográficas e econômicas, faz com que muitos cidadãos residentes fiquem a maior parte do dia fora de casa e, ainda, atrai muitos cidadãos residentes em cidades vizinhas, tanto por motivos relacionados com o trabalho, quanto por motivos de compras ou outro qualquer. Como devem se portar esses cidadãos em relação ao funcionamento dos serviços vinculados à Atenção Básica? E aqueles que têm problemas como "enfermidades e traumatismos comuns", não deveriam procurar os serviços da Atenção Básica na cidade?

O não atendimento, pronto, rápido, à demanda por problemas como os previstos, desde Alma-Ata, não é um problema só do PSF. Os registros de frases significativas dos discursos de trabalhadores da saúde vinculados a serviços de Atenção Básica, em alguns espaços institucionais, semelhante ao que se ouvia tempos atrás, entre sanitaristas ditos mais fundamentalistas, mas que, em ambas as situações, parece não terem conhecimento sequer da Declaração de Alma-Ata.

Seja qual for o modelo assistencial priorizado, se não há referência teórica e ética, se não há compromisso com as necessidades da população - mesmo aquelas não detectadas por estudos epidemiológicos -, com o sistema, fica difícil melhorar a capacidade resolutiva da Atenção Básica. Por outro lado, se não há gestão que acolha essas necessidades não detectadas pelos instrumentos tradicionais, fica mais difícil ainda. Hoje, a atenção básica do município tem muitos gerentes, que cumprem bem as orientações e normas de seus superiores. Mas, essa área estratégica do SUS ainda necessita de gente bem formada, com perfil e capacidade de gestão.

Uma questão relevante é a que diz respeito ao apelo popular para um ator social, embora muito desrespeitado, com muito interesse nessa questão. Dito de outra 
maneira, esse modelo de pronto atendimento oferta à população um serviço que atende se não necessidades de saúde, enquanto conceito vinculado à epidemiologia, pelo menos atende expectativas populares de poder acessar o serviço de saúde quando melhor lhe convém. E, ainda, a porta do pronto atendimento fica mais tempo aberta e não é preciso que o usuário seja rotulado ou classificado com uma das prioridades do programa ou serviço para poder acessá-lo. Nesse sentido, é muito significativo o relato de uma senhora idosa, militante de um movimento popular da região da STSe, sobre um atendimento recente recebido por ela, em uma AMA: “Eu gostei. Não demorou nadinha para eu ser atendida. [...] Nem precisei marcar consulta! [...] E, ainda, tinha 'rau-X'! [...] Foi bom. Eu tava ocupada, [...] fui atendida logo e por médico! E voltei logo pra casa, para as minhas tarefas”. Vale registrar que o movimento popular do bairro, que inclusive essa cidadã-usuária participa, foi um dos exemplos de ator social que questionou e acabou conseguindo inviabilizar a implantação da AMA nas dependências da UBS do referido bairro.

Mesmo os atores desse segmento, mais articulados a movimentos sociais mais amplos, ou mais politizados, quando criticaram essa iniciativa, não a desqualificaram. Nas últimas Conferências Municipais de Saúde da capital esse tema foi debatido e as críticas mais contundentes ou que geraram teses e posicionamentos mais antagônicos estavam relacionadas com a gestão terceirizada do processo de implantação das AMAs. Além de algumas teses contrárias à gestão terceirizada para as entidades "parceiras", outras formulações e teses desse fórum, com origem em setores dos atores sociais que não os gestores - trabalhadores da saúde ou movimentos sociais - estavam se posicionando mais no sentido de fortalecer o "pólo 
fraco", ou seja, aumentar os investimentos nos serviços da Atenção Básica e mesmo nos prontos-socorros municipais (São Paulo.CMS, 2005; 2007).

O processo de implementação das AMAs, dentro de UBSs reacendeu o debate tanto sobre o caráter, pertinência, tamanho da necessidade, quanto sobre a possibilidade de integração entre esses modelos assistenciais quase polares, representados, de um lado, por serviços de Atenção Primária em Saúde, organizados com ações programáticas e, de outro, os serviços de pronto atendimento, onde o elemento central é a assistência médica, baseada quase exclusivamente na queixa - conduta.

Vale ressaltar que, como destacado por outros autores, existe uma tensão latente, por vezes, antagônica entre esses dois modos de organizar a assistência, relacionada com as diferenças inerentes a como cada um intervém sobre as necessidades em saúde da população, como já foi discutido por outros (Dalmaso, 1993). E, também, motivadas pelas contradições e conflitos entre os atores sociais envolvidos ou interessados na questão, sejam estes gestores, trabalhadores da saúde ou população usuária.

Nesse sentido, estudo realizado em época cujas tensões repercutiam menos, que avaliou aspectos de integração sanitária entre serviços organizados por lógicas distintas - assistência médico-sanitária, ou programática, concentrada no PAM; e assistência médica individual, de caráter curativa, concentrada no PA -, em um estabelecimento municipal, caracterizam essa questão (Tanaka e Rosenburg, 1990). Embora estejamos discutindo o modelo tecnoassistencial hegemônico, é importante considerar essas questões mais relacionadas com a gestão do sistema, pois algumas medidas adotadas de forma a valorizar mais uma das dimensões acaba repercutindo na outra. Nesse sentido, uma avaliação das AMAs realizada pelo Conselho Regional de Medicina aborda essa questão, surgida em uma vistoria de um serviço desse 
instalado em um pronto-socorro, quando identifica nessa opção "uma estratégia que visa contornar as dificuldades de contratação de médicos para o PS, uma vez que com a instalação da AMA vem a parceira e com ela a superação das dificuldades com a política salarial da administração direta” (Cremesp, 2007, p.5).

O pronto atendimento médico e as ações programáticas, além de serem formas distintas de se organizar a assistência à saúde, na complexa dinâmica de forças e partidos políticos em disputa e das variada alternância no poder e, em particular, das políticas implementadas na capital paulistana têm potencial para assumir identidades com determinados campos político-ideológicos das disputas presentes na cidade.

A partir dos anos 1980, o município de São Paulo, seja por sua relativa autonomia, seja por seu peso político no cenário nacional, tem experimentado na política de saúde esse largo espectro de opções partidárias e, conseqüentemente, de prioridades políticas. Ora se investe em um programa ou modelo assistencial, ora em outro em sentido contrário ao anterior. Nem todos são antagônicos a ponto de serem incompatíveis na realidade do SUS da capital. Mas, quando esses modelos se configuram para a opinião pública como uma marca de governo, aí a sustentação político-institucional e mesmo técnica passa a sofrer risco quanto a sua continuidade no tempo.

\section{Considerações Finais}

A implementação do projeto de unidades AMA não apresenta, na prática, uma inovação assistencial como se quer associar a esse programa/política que foi assumida como prioridade de governo, não só do setor saúde, constituindo-se inclusive uma marca de governo de forte apelo popular, na disputa política e eleitoral 
de 2008. Pode-se caracterizar as AMA como serviços de pronto atendimento típicos, centrado na consulta médica, de tipo clássico baseada na relação queixa - conduta, embora disponham de alguns recursos e serviços de apoio diagnóstico à disposição. Independentemente dos altos custos para sua manutenção, é uma política que, por suas origens e potencial de diálogo com necessidades e demandas populares não incorporadas na rotina da Atenção Básica brasileira pode, em curto prazo, se expandir para outras regiões do país. E, na dependência do desempenho político e eleitoral da frente partidária, que hoje governa a capital e o estado, em médio prazo de tempo, pode ganhar status de política nacional.

Contudo, vale registrar que as AMAs, na sua maioria, mesmo tendo sido implantadas de forma acoplada a UBSs, não conseguem integrar com os serviços desenvolvidos pelas UBSs por terem equipes diferenciadas, salários diferenciados e, principalmente, por não trabalharem com os prontuários sequer dos cidadãosusuários residentes na área de abrangência do serviço. Nesse sentido, não conseguem promover a integração sanitária sequer com as equipes do estabelecimento de saúde que lhe dá acolhida e estrutura física de abrigo. Não promovem tampouco as premissas da integralidade da assistência à saúde entre as equipes de trabalho do mesmo estabelecimento: profissionais da equipe da UBS "tradicional"; profissionais da equipe do PSF; e profissionais da equipe da AMA.

\section{Referências}

ALVES, O.S.F.; MORAIS, M.L.S.; MOTT, M.L.B. Narrativas de vivências em Políticas Públicas no Estado de São Paulo. 13p. Disponível em:

<http://www.cfh.ufsc.br/abho4sul/pdf> Acesso em: 20 out. 2008. 
BRASIL. Lei Federal nº 8.080, de 19 de setembro de 1990. Dispõe sobre as condições para a promoção, proteção e recuperação da saúde, a organização e o funcionamento dos serviços correspondentes. Diário Oficial da União, Brasília, DF, 20 set. 1990. Seção 1, p.18055.

CAMPOS, G.W.S. Reforma da Reforma: repensando a saúde. São Paulo: Ed. Hucitec, 1992. 220p.

COHN, A.; ELIAS, P.E. (Coord.). O Público e o Privado na Saúde: o PAS em São Paulo. São Paulo: Ed. Cortez, 1999. 248p.

CREMESP - Conselho Regional de Medicina do Estado de São Paulo. Análise das condições de funcionamento das unidades de Assistência Médica Ambulatoriail AMAs, do município de São Paulo - 2006. São Paulo: Cremesp, 2007. 32p. [mimeo] DALMASO, A.S.W. O atendimento não-programado: o pronto-atendimento nas ações programáticas em saúde. In: SCHRAIBER, L.B. (Org.). Programação em Saúde Hoje. $2^{\mathrm{a}}$ ed. São Paulo: Ed. Hucitec, 1993. p.227-243.

DENIS, J.; CHAMPAGNE, F. Análise da implantação. In: HARTZ, Z.M.A. (Org.). Avaliação em Saúde: dos modelos conceituais à prática na análise da implantação de programas. Rio de Janeiro: Ed. Fiocruz, 1997. p.49-88.

DRAIBE, S.M. Avaliação de implementação: esboço de uma metodologia de trabalho em políticas públicas. In: BARREIRA, M.C.R.N.; CARVALHO, M.C.B. Tendências e Perspectivas na Avaliação de Políticas e Programas Sociais. São Paulo: IEE/PUC-SP, 2001. p. 13-42.

FURTADO, L.A.C.; TANAKA, O.Y. Processo de construção de um distrito de saúde na perspectiva de gestores e médicos: estudo de caso. Revista de Saúde Pública, São Paulo, v.32, n.6, p.587-595, 1998.

GERSCHMAN, S.; SANTOS, M.A.B. O Sistema Único de Saúde como desdobramento das políticas de saúde do século XX. Revista Brasileira de Ciências Sociais, São Paulo, vol.21, n.61, p.177-190, jun. 2006.

GUIMARÃES, C. Situação assistencial brasileira. In: GONÇALVES, E.L. (Coord.). Administração de Saúde no Brasil. São Paulo: Ed. Pioneira, 1982. p.103-137. 
KEINERT, T.M.M. Política pública de saúde, inovação e o Plano de Atendimento à Saúde do município de São Paulo. RAE - Revista de Administração de Empresas, São Paulo, v.37, n.3, p.78-85, jul./set. 1997.

LAPASSADE, G. A observação participante. In: . As Microssociologias. Brasília, DF: Liber Livro Ed., 2005. p. 69-90.

MAGALHÃES Jr, H.M. Urgência e emergência: a participação do município. In: CAMPOS, C.R.; et al. (Org.). Sistema Único de Saúde em Belo Horizonte: reescrevendo o público. São Paulo: Ed. Xamã, 1998. p.265-286.

MERHY, E.E. A Saúde Pública Como Política: um estudo de formuladores de políticas. São Paulo: Ed. Hucitec, 1992. 221p.

OLIVEIRA, J.A.A.; TEIXEIRA, S.M.F. (Im)Previdência Social: 60 anos de história da Previdência no Brasil. $2^{\text {a }}$ ed. Petrópolis: Ed. Vozes, 1989. 360p.

OMS - Organización Mundial de la Salud. Atención Primaria de Salud. [Informe de la Conferencia Internacional sobre Atención Primaria de Salud. Alma-Ata, URSS, 612 sep.1978]. Ginebra: OMS (Série "Salud Para Todos", No 1), 1978. 91p.

PEREIRA, D. Industrialização deformada. In: PEREIRA, R.R. (Ed.). Retrato do Brasil: da monarquia ao estado militar. Ed. Política, 1984. Vol.2, p.457-462.

RAMOS, R. A Integração Sanitária: doutrina e prática. 1972. 366 p. Tese (Livre Docência em Saúde Pública) - Faculdade de Saúde Pública, Universidade de São Paulo, São Paulo.

SÃO PAULO. SMS - Secretaria Municipal da Saúde. Assistência Médica Ambulatorial - AMA. Disponível em: <http://portal.prefeitura.sp.gov.br/secretarias/saude/organizacao/0006> Acesso em: 15 out. 2008.

SÃO PAULO (Município). CMS - Conselho Municipal de Saúde. Ata da $78^{a}$ reunião ordinária do Conselho Municipal de Saúde. São Paulo: CMS-SP/SMS-SP, 16 jun. 2005. 19p. Disponível em: $<$ http://ww2.prefeitura.sp.gov.br//arquivos/secretarias/saude/cms/0019/ata_2005_78_ ord.pdf> Acesso em: 15 out. 2008. 
SÃO PAULO (Município). CMS. $13^{a}$ Conferência Municipal de Saúde - São Paulo: efetivando o controle social no SUS (Relatório Final). São Paulo: 19 a 21 dez. 2005. 32p. Disponível em:

$<$ http://ww2.prefeitura.sp.gov.br//arquivos/secretarias/saude/cms/0011/XIII_Conf_M un_Saude.pdf> Acesso em: 25 out. 2008.

SÃO PAULO (Município). CMS. $14^{a}$ Conferência Municipal de Saúde de São Paulo (Relatório Final). São Paulo: 3 set. 2007. 55p. Disponível em:

<http://ww2.prefeitura.sp.gov.br//arquivos/secretarias/saude/cms/0011/RelatorioFina 1_14_ConferenciaVersaoCMS_Produto3.pdf> Acesso em: 25 out. 2008.

TANAKA, O.Y.; ROSENBURG, C.P. Análise da utilização pela clientela de uma unidade ambulatorial da Secretaria da Saúde do Município de São Paulo, SP (Brasil). Revista de Saúde Pública, São Paulo, v.24, n.1, p.60-68, 1990.

WALT, G. et al. 'Doing' health policy analysis: methodological and conceptual reflections and challenges. Health Policy and Planning, v.23, p.308-317, 2008. WEISS, C.H. Evaluation: methods for studying programs and policies. $2^{\text {nd }}$ ed. Upper Saddle River: Prentice Hall, 1998. 372p.

YIN, R.K. Case Study Research: design and methods. $2^{\text {nd }}$ ed. Thousand Oaks: Sage, 1994. 171p. 


\section{CONSIDERAÇÕES FINAIS}




\section{CONSIDERAÇÕES FINAIS}

Esperamos ter conseguido levantar e problematizar algumas questões relevantes para o progresso do SUS, avaliando aspectos da incorporação da integralidade no processo de (re)construção do sistema de saúde no Município de São Paulo, no período de 2001 a 2008, nos marcos e limites de uma pesquisa avaliativa e, predominantemente, qualitativa.

Nesse sentido, procuramos neste trabalho analisar os achados da pesquisa e da experiência empírica - projetos, estratégias, movimentos, argumentos -, visando problematizar sua consistência empírica e conceitual. Para tanto, organizamos estas considerações finais de forma a resgatar os recortes temáticos que forneceram a base para a elaboração dos três artigos apresentados nesta tese, com suas principais questões, mesmo que estas fossem recorrentes.

Em relação aos achados mais relevantes da pesquisa empírica, no primeiro recorte temático - aquele explorado por meio da identificação e avaliação das políticas de saúde priorizadas na primeira gestão e que tiveram sustentação política, nos dois períodos de gestão estudados - e que dizem respeito à adesão do Município de São Paulo ao SUS e, conseqüentemente, a seus princípios. Observou-se o município extinguiu o Plano de Assistência à Saúde, que foi identificado como uma experiência gerencialista que não respeitava princípios do SUS, e vinha implementando políticas de saúde que respeitavam os princípios constitucionais da universalidade, particularmente de acesso à atenção básica, e da participação e controle social do 
SUS, com conflitos e solução de continuidade por poucos meses no segundo período de gestão.

As reorganizações administrativas, separando as instâncias de coordenação da atenção ambulatorial, de um lado, e de coordenação da atenção hospitalar, de outro, sem instrumentos de gestão que propiciassem uma efetiva integração funcional e institucional, levou à constituição do se denominou, aqui, de dois subsistemas municipais de serviços de saúde. Esse fato, associado à precária integração com os hospitais e ambulatórios de especialidades estaduais e que continuavam sob gestão, de fato, estadual, mantinha a fragmentação do SUS no município em três subsistemas público-estatais de saúde funcionando em paralelo, com lógicas distintas e pouca integração de serviços na prática. Embora o município tenha sido habilitado, em relativo curto espaço de tempo, na gestão plena do sistema municipal, essa situação de fragmentação do sistema em três perdurou até o final do período estudado. Identificou-se, nessa conformação do SUS em três subsistemas de saúde funcionando em paralelo, um importante obstáculo para uma melhor articulação e integração entre serviços de distintas densidades tecnológicas, o que dificulta a incorporação da integralidade da assistência no desenvolvimento do SUS no município. Nesse contexto, foi identificada instituição hospital - com sua tradição, papel e poder historicamente constituídos - como um fator interveniente na fragmentação do sistema e, conseqüentemente, dificultando e fragilizando a possibilidade da incorporação da integralidade da assistência do SUS no município.

Uma variável condicionante sobre a compreensão e implementação do SUS como política pública, bem como de princípios complexos e trabalhosos como a busca da "imagem objetivo" da incorporação da integralidade da assistência foi associada com 
o perfil profissional e a trajetória pública dos gestores municipais da saúde. Dos seis secretários que se alternaram na direção da SMS-SP, apenas três tinham alguma formação profissional na área da saúde pública/coletiva e/ou trajetória vinculada ao processo de construção do SUS no país. Discute-se a necessidade dos gestores conheceram o SUS para melhor qualificar sua capacidade de governo, independentemente de outras articulações e afiliações que estes possam ter. A alta rotatividade dos gestores da saúde observada, no período de estudo, foi identificada como outro condicionante para fragilizar políticas de saúde prioritárias, comprometendo sua sustentação política no decorrer do tempo, tanto internamente no governo municipal, quanto externamente na relação entre gestores (municipais, estadual e federal).

No âmbito do modelo assistencial e limitado à atenção básica, o Programa de Saúde da Família (PSF) foi identificado como uma das políticas priorizadas, com sustentação política durante as duas gestões. Isso foi associado com o fato desse programa ter abrangência nacional e ser prioridade do gestor federal do SUS, com estímulo financeiro vinculado, bem como ao fato da primeira gestão ter usado o nome "genérico" do programa - PSF - e por este não ter se constituído em "marca política" da gestão municipal. Em que pese o fato dessa política ser caracterizada como um tipo de isomorfismo institucional, induzida pelo Ministério da Saúde, foram discutidos os esforços despendidos pela SMS-SP, as dificuldades para se expandir o programa em municípios de grande porte. A estratégia de implantação do programa no município pode ser caracterizada como tendo um viés "substitutivo" das equipes das unidades básicas de saúde "tradicionais". Nesse sentido, a estratégia adotada não consegue propiciar cobertura a populações desassistidas, configurando o 
que um dos gestores classificou como os buracos de um "queijo suíço". E, por fim, pode-se associar outra estratégia implantação do PSF, por meio de parcerias com entidades privadas, como uma contradição. Na medida em que essas parcerias, para a gestão de pessoal do programa, são caracterizadas como um instrumento de gestão de caráter gerencialista, que fragiliza a força de trabalho que, no setor saúde, é estratégica e tem potência para dar continuidade e sustentação às políticas.

Em relação ao segundo recorte temático - aquele explorado por meio da identificação e avaliação de estratégias, movimentos e ações dos atores institucionais, com referência na "imagem objetivo" da integralidade, nos dois períodos de gestão estudados - e que dizem respeito à construção de uma direção única do SUS no Município de São Paulo. No contexto do processo de habilitação do município na gestão plena do sistema municipal, discute-se o desafio e as dificuldades para negociar um pacto com a SES-SP, para que a SMS-SP assumisse a gestão dos serviços estaduais de média complexidade vinculados, tanto a ambulatórios, como a hospitais gerais ou especializados não-universitários. Discutese que a manutenção da gerência dos hospitalares e ambulatoriais especializados estaduais com a SES-SP, ainda que alguns sob gestão compartilhada com a SMS-SP, é um fator que dificulta a garantia da integralidade da assistência do SUS municipal. E que este ficou dependente da SES-SP - que possui e organiza a maioria dos recursos de média e alta complexidade públicos - e do setor privado - que, por intermédio dos prestadores privados, deveria atuar de forma complementar.

A estratégia de se construir um sistema de regulação é avaliada como limitada e frágil, pela dificuldade de negociar acordos políticos dos gestores, SMS-SP e SESSP, perder e ganhar poder. Nessa aproximação à realidade da gestão do SUS no 
município, reapareceu fortemente a questão do poder e autonomia dos hospitais em relação aos demais serviços de saúde. E, do fato de os gestores, embora sejam conhecedores em detalhes do problema, não terem um projeto político para lidar com essa instituição - hospital. Discute-se a implementação de um novo instrumento de gestão informatizado, o SIGA Saúde, que, embora necessário e tendo sustentação técnica e política por duas gestões, se mostrava frágil por não ser respaldado por acordos negociados, articulação e integração entre os atores institucionais. Frágil por não conseguir garantir o acesso a serviços gerenciados por outros (SES-SP e prestadores privados, que vendem o que e quando querem). É discutida a prática dos "acordos regionais", nas quais os hospitais estaduais tinham autonomia e poder para ofertar - ou não - serviços para as regionais da SMS-SP. Pois, segundo o representante da SES-SP “O hospital não se sente responsabilizado, do ponto de vista de instância secundária da região. Hospital tem um papel de hospital! [...] A porta do hospital é sua grande motivação! [...] A responsabilidade do hospital é dar conta do pronto-socorro".

Na esfera política e partidária, discute-se o fato de, desde o início de 2005, as duas gestões - estadual e municipal - serem da mesma frente político-partidária e, mesmo assim, não haver evidências de progresso em termos de negociação e construção de uma direção única do SUS no município. Registra-se uma iniciativa da gestão municipal em criar mecanismos interinstitucionais regionais, para integrar instâncias regionais da SMS-SP com serviços da SES-SP, que teve pouco apoio e foi abandonada. Se essa iniciativa lograsse apoio institucional e sustentação política, poderia melhorar a articulação e integração entre os gestores dos dois subsistemas municipal e estadual - para facilitar e racionalizar o acesso da população atendida na 
rede de saúde municipal ou municipalizada para os serviços de média e alta complexidades sob gestão estadual. Se prosperasse, essa iniciativa poderia ser um ensaio, um exercício prático de incorporação da integralidade da assistência no SUS da capital.

O que se evidenciou foi um movimento do governo do Estado consolidando, na saúde, um projeto político distinto daquele negociado com a SMS-SP e o Ministério da Saúde, na habilitação do município na gestão plena do sistema municipal. Evidenciou-se a fragilidade do processo de negociação entre a SES-SP e a SMS-SP e, entre 2005 e 2006, foi implementada uma reforma administrativa na SES-SP institucionalizando seu papel de gestora de fato e de direito dos serviços estaduais de média e alta complexidades na cidade. Discutem-se resistências em processos similares ao registrado no caso do Município de São Paulo, que tendem a dificultar processos de integração de serviços de saúde e, conseqüentemente, resultam em dificuldades adicionais ao processo de incorporação da integralidade. Essa situação, por outro recorte, trouxe à pauta novamente a fragmentação do SUS no município, agora pela expressão e manutenção de dois subsistemas públicos funcionando em paralelo, um estadual e outro municipal, o que dificulta a incorporação da integralidade da assistência à saúde. Nesse contexto, são discutidas as conseqüências e ineficiências associadas à fragmentação do SUS, como a atenção descontínua, a forte polarização entre hospital e ambulatório, bem como a ausência de integração. Registra-se a existência, na agenda pública brasileira, de um projeto de "reforma administrativa" do SUS, que propõe sua reorganização em dois subsistemas. Um de “entrada e controle”, concentrando serviços da atenção básica, que funcionaria como 
um modelo do tipo gatekeeper do acesso aos serviços de média e alta complexidades do SUS municipal, e outro de "referência ambulatorial e hospitalar".

Por fim, no contexto da autonomia dos hospitais, problematiza-se a possibilidade de se viabilizar a gestão de um sistema municipal e, conseqüentemente de serviços e estabelecimentos de saúde, sem a gerência daqueles considerados estratégicos para o SUS. E discute-se o desafio de implementar uma direção única da saúde no SUS implica em uma (re)divisão de recursos e poder. Negociar e pactuar uma direção única constituem-se um problema e um grande desafio políticos, necessitando, além de instrumentos de gestão, de abordagens macroestruturais e macropolíticas.

Finalmente, em relação ao terceiro recorte temático - aquele explorado por meio da avaliação do processo de implantação do projeto de unidades de AMA, na lógica da integralidade do SUS e do modelo assistencial, na medida em que a maioria delas foi acoplada a UBSs pré-existentes, no período da gestão 2005-2008 - que diz respeito à discussão da integração de serviços de saúde no Município de São Paulo. A discussão parte de uma análise inicial em que se discute a baixa resolutividade da atenção básica e o excesso de fila nos poucos prontos socorros públicos. Nesse contexto, ao que parece, esse novo serviço estaria respondendo a parte da demanda por serviços de pronto atendimento na cidade. Delineia-se e identifica-se o "novo" serviço, denominado AMA (assistência médica ambulatorial), mais como um tipo pronto atendimento do que uma "inovação" assistencial. Discute o quanto ele pode conviver com os modelos tradicionais de UBSs ou mesmo aqueles serviços organizados sob um suposto novo paradigma, que hoje, no Brasil, estão concentrados nas equipes de PSF. Associam-se a baixa resolutividade e baixa acessibilidade da Atenção Básica, incluindo o PSF do município, tanto à formação deficiente e à alta 
rotatividade dos profissionais, particularmente, dos médicos, quanto à falta de uma gestão local mais consistente. Associa-se, ainda, esse problema a uma postura ideológica dos profissionais, que abstraem a necessidade da população de um atendimento médico imediato, atribuindo-lhe uma suposta ignorância sobre o papel da Atenção Básica ou da Atenção Primária em Saúde (APS). Reconhece-se que, se as demandas ou problemas agudos não são atendidos prontamente e próximo ao local de moradia, as portas dos poucos e precários prontos-socorros públicos do município fiquem cada vez mais cheios e com filas cada vez maiores.

Recuperam-se a conferência de Alma-Ata e a concepção de Atenção Primária de Saúde, bem como dois conteúdos fundamentais. Um que caracteriza a APS como "o primeiro nível de contato dos indivíduos, das famílias e da comunidade com o sistema de saúde, levando o cuidado à saúde o mais próximo do lugar onde residem e trabalham as pessoas". E outro, que detalha a abrangência da APS, compreendendo inclusive "o tratamento apropriado das enfermidades $e$ traumatismos comuns". No contexto da cidade de São Paulo, com suas características sócio-demográficas e econômicas, discute como deveriam se portar os cidadãos em relação ao funcionamento dos serviços vinculados à Atenção Básica. E que o não atendimento, pronto, rápido, à demanda por problemas como os previstos, desde Alma-Ata, não é um problema só do PSF.

É discutido que, independentemente do modelo assistencial priorizado, se não existe referência teórica e ética, se não existe compromisso com as necessidades da população, com o sistema, fica difícil melhorar a capacidade resolutiva da Atenção Básica. Por outro lado, se não há gestão que acolha essas necessidades não detectadas pelos instrumentos tradicionais, fica mais difícil ainda. 
Uma questão relevante discutida diz respeito ao apelo popular que esse modelo de pronto atendimento oferta à população um serviço que atende se não necessidades de saúde, enquanto conceito vinculado à epidemiologia, pelo menos atende expectativas populares de poder acessar o serviço de saúde quando melhor lhe convém. E, ainda, a porta do pronto atendimento fica mais tempo aberta e não é preciso que o usuário seja rotulado ou classificado com uma das prioridades do programa ou serviço para poder acessá-lo. Mesmo os atores desse segmento, mais articulados a movimentos sociais mais amplos, ou mais politizados, quando criticaram essa iniciativa, não a desqualificaram. Nas últimas Conferências Municipais de Saúde da capital, as críticas estavam relacionadas com a gestão terceirizada do processo de implantação das AMAs, com algumas teses contrárias à gestão terceirizada para as entidades "parceiras".

A implementação das AMAs não representa uma inovação assistencial, podendo ser caracterizado como serviços de pronto atendimento típicos, centrado na consulta médica, de tipo clássico baseada na relação queixa - conduta, visando mais a diminuição das filas dos prontos-socorros. É uma política que, por suas origens e potencial de diálogo com necessidades e demandas populares não incorporadas na rotina da Atenção Básica brasileira pode, em curto prazo, se expandir para outras regiões do país. Por fim, ressalta-se que as AMAs não conseguem integrar com os serviços desenvolvidos pelas UBSs por terem equipes diferenciadas, salários diferenciados e, principalmente, por não trabalharem com os prontuários sequer dos cidadãos-usuários residentes na área de abrangência do serviço. Não conseguem promover a integração sanitária sequer com as equipes do estabelecimento de saúde que lhe dá acolhida e estrutura física de abrigo. Não promovem tampouco as 
premissas da integralidade da assistência à saúde entre as equipes de trabalho do mesmo estabelecimento: profissionais da equipe da UBS “tradicional”; profissionais da equipe do PSF; e profissionais da equipe da AMA.

Embora limitados por questões relacionadas ao acesso a espaços de gestão específicos e pelas limitações do próprio autor, na identificação de outras informações relevantes, este trabalho conseguiu mostrar alguns rumos e apontar para potencialidades, neste tipo de abordagem. Por outro lado, com os três recortes temáticos, teve consistência suficiente para embasar parte considerável de nossa problematização sobre problemas, insuficiências e desafios do SUS em municípios de grande porte, bem como buscou explorar ao máximo as poucas e pontuais iniciativas da gestão que favorecem e/ou dificultam a promoção da integralidade da assistência à saúde no SUS. 
6. REFERÊNCIAS 


\section{REFERÊNCIAS ${ }^{4}$}

ALMEIDA, C.M. Reforma do Estado e reforma de sistemas de saúde: experiências internacionais e tendências de mudança. Ciência \& Saúde Coletiva, Rio de Janeiro, v.4, n.2, p.263-286, 1999.

ALMEIDA, P.F.; GIOVANELLA, L.; MATTOS, M. Sistema de saúde brasileiro: dilemas da universalização. Saúde em Debate, Rio de Janeiro, v.26, n.61, p.137$154,2002$.

ARRETCHE, M. Mitos da descentralização: mais democracia e eficiência nas políticas públicas? Revista Brasileira de Ciências Sociais, São Paulo, v.31, n.11, p.44-66, 1996. Disponível em:

$<$ http://www.anpocs.org.br/portal/publicacoes/rbcs_00_31/rbcs31_03.htm >. Acesso em: 29 dez. 2008.

ARRETCHE, M.; MARQUES, E. Municipalização da saúde no Brasil: diferenças regionais, poder do voto e estratégias de governo. Ciência \& Saúde Coletiva, Rio de Janeiro, v.7, n.3, p.455-479, 2002.

BARATA, L.R.B.; TANAKA, O.Y.; MENDES, J.D.V. Por um processo de descentralização que consolide os princípios do Sistema Único de Saúde.

Epidemiologia e Serviços de Saúde, Brasília, v.13, n.1, p.15-24, 2004a.

BARATA, L.R.B.; TANAKA, O.Y.; MENDES, J.D.V. 15 anos de SUS: desafios e perspectivas (2003). In: CONASS. Convergências e Divergências sobre Gestão e Regionalização do SUS. Agosto de 2004b. Disponível em:

<http://dtr2001.saude.gov.br/dad/PactoGestao/docs>. Acesso em: 21 mar. 2005.

BRASIL. Constituição (1988). Constituição da República Federativa do Brasil. Brasília, DF: Senado, 1988.

BRASIL. Lei $\mathrm{n}^{\circ}$ 8.080, de 19 de setembro de 1990. Dispõe sobre as condições para a promoção, proteção e recuperação da saúde, a organização e o funcionamento dos

${ }^{4}$ As referências listadas neste capítulo estão relacionadas a citações contidas nos capítulos 1 e 3 . 
serviços correspondentes, e dá outras providências. Diário Oficial da União, Brasília, DF, 20 set. 1990a.

BRASIL. Lei no 8.142, de 28 de dezembro de 1990. Dispõe sobre a participação da comunidade na gestão do Sistema Único de Saúde (SUS) e sobre as transferências intergovernamentais. Diário Oficial da União, Brasília, DF, 31 dez. 1990 b.

BRASIL. MARE - Ministério da Administração Federal e Reforma do Estado.

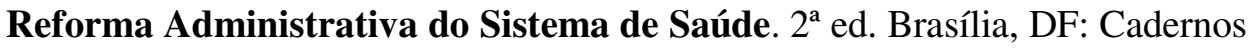
MARE de Reforma do Estado, n.13, 1998. 43p. Disponível em: <http://www.bresserpereira.org.br/Reforma_Gerencial_de_1995>. Acesso em: 29 dez. 2008.

BRASIL. MS - Ministério da Saúde. GM - Gabinete do Ministro. Portaria MS/GM n 1.399 , de 22 de julho de 2003. Habilita o Município de São Paulo conforme Anexo desta Portaria, na Gestão Plena de Sistema Municipal. Diário Oficial da União, Brasília, DF, 23 jul. 2003.

CARVALHO, B.G.; MARTIN, G.B.; CORDONI Jr, L. A organização do sistema de saúde no Brasil. In: ANDRADE, S.M.; SOARES, D.A.; CORDONI Jr, L. (Org.).

Bases da Saúde Coletiva. Londrina: Ed. UEL/Abrasco, 2001. p. 27-59.

CASTRO, C.G.J. O Processo de Implantação do Sistema Único de Saúde (SUS): estudo de caso em município de gestão semi-plena. 1999. Tese (Doutorado em Saúde Pública) - Faculdade de Saúde Pública, Universidade de São Paulo, São Paulo.

CECILIO, L.C.O. As necessidades de saúde como conceito estruturante na luta pela integralidade e eqüidade na atenção à saúde. In: PINHEIRO, R.; MATTOS, R.A. (Org.). Os Sentidos da Integralidade na atenção e no cuidado à saúde. Rio de Janeiro: UERJ, IMS/Abrasco, 2001. p. 113-126.

CNS - CONSELHO NACIONAL DE SAÚDE. Desenvolvimento do Sistema Único de Saúde no Brasil: avanços, desafios e reafirmação de princípios e diretrizes. Saúde em Debate, Rio de Janeiro, v.26, n.62, p.295-310, 2002.

COHN, A. As políticas sociais no governo FHC. Tempo Social, Rev. Sociol. USP, São Paulo, v.11, n.2, p.183-197, 1999. 
COHN, A.; ELIAS P.E. (Coord.). O Público e o Privado na Saúde: o PAS em São Paulo. São Paulo: Ed. Cortez/Cedec, 1999.

COHN, A.; ELIAS, P.E.; IANNI, A.M.Z. O público e o particular no Hospital das Clínicas de São Paulo. In: NEGRI, B.; VIANA, A.L.A. (Org.). O Sistema Único de Saúde em dez anos de desafio. São Paulo: Sobravime/Cealag, 2002. p. 555-572. CONASEMS - CONSELHO NACIONAL DE SECRETÁRIOS MUNICIPAIS DE SAÚDE. Teses e Plano de Ação: 2005-2007. Brasília, DF, 2005. Disponível em: $<$ http://www.conasems.org.br>. Acesso em: 11 out. 2005.

CORDONI Jr, L. Política de saúde nos anos 90 e a reforma sanitária - considerações sobre o artigo "Política de saúde nos anos 90: relações intergovernamentais e o papel das Normas Operacionais Básicas". Ciência \& Saúde Coletiva, Rio de Janeiro, v.6, n.2, p.306-307, 2001.

CORREIA, M.V.C. Que Controle Social? Os conselhos de saúde como instrumento. Rio de Janeiro: Ed. Fiocruz; 2000.

DENIS, J.L.; CHAMPAGNE, F. Análise da Implantação. In: HARTZ, Z.M.A. (Org.). Avaliação em Saúde: dos modelos conceituais à prática na análise da implantação de programas. Rio de Janeiro: Ed. Fiocruz, 1997. p. 49-88.

DESLANDES, S.F.; GOMES, R. A pesquisa qualitativa nos serviços de saúde: notas teóricas. In: BOSI, M.L.M.; MERCADO, F.J. (Org.). Pesquisa Qualitativa de Serviços de Saúde. Petrópolis: Ed. Vozes, 2004. p. 99-120.

DRAIBE, S.M. Avaliação de implementação: esboço de uma metodologia de trabalho em políticas públicas. In: BARREIRA, M.C.R.N.; CARVALHO, M.C.B. Tendências e Perspectivas na Avaliação de Políticas e Programas Sociais. São Paulo: IEE/PUC-SP, 2001. p. 13-42.

ELIAS, P.E. Reforma e contra-reforma na proteção à saúde. Lua Nova, São Paulo, 40/41, p.193-216, 1997.

ELIAS, P.E. Estado e saúde: os desafios do Brasil contemporâneo. São Paulo em Perspectiva , São Paulo, v.18, n.3, p.41-46, 2004. 
FERREIRA, S.C.C. Aspectos da Integralidade do SUS: um estudo de caso na A.P.3.1 no município do Rio de Janeiro. 2003. Dissertação (Mestrado em Saúde Pública) - Escola Nacional de Saúde Pública, Fiocruz, Rio de Janeiro.

FRANCO, T.B.; MAGALHÃES Jr, H.M. Integralidade na assistência à saúde. In: MERHY, E.E. et al. O Trabalho em Saúde: olhando e experienciando o SUS no cotidiano. São Paulo: Ed. Hucitec, 2003. p. 125-133.

FURTADO, L.A.C. Distrito de Saúde e a Assistência Integral: o caso do Distrito de Saúde de Santana - São Paulo - 1989/1992. 1995. Dissertação (Mestrado Saúde Pública) - Faculdade de Saúde Pública, Universidade de São Paulo, São Paulo.

GERSCHMAN, S. A descentralização da política de saúde no final dos anos 1990. RAP - Revista de Administração Pública, Rio de Janeiro, v.34, n.4, p.147-170, 2000.

GIOVANELLA, L. et al. Sistemas municipais de saúde e a diretriz da integralidade da atenção: critérios para avaliação. Saúde em Debate, Rio de Janeiro, v.26, n.60, p.37-61, 2002.

GODOY, A.S. Pesquisa qualitativa: tipos fundamentais. RAE - Revista de Administração de Empresas, São Paulo, n.35, v.3, p.20-29, 1995.

GUIMARÃES, L. El encuentro entre descentralización y la democracia: la participación ciudadana. In: Modalidades de descentralización del sector salud y sus contribuciones a la equidad: elementos fundamentales para la formulación de un marco normativo. Washington, DC: Organización Panamericana de la Salud (Programa de Políticas Públicas/Serie Informes Técnicos No. 76), 2001. p. 6-7.

HARTZ, Z.M.A.; CONTANDRIOPOULOS, A.-P. Integralidade da atenção e integração de serviços de saúde: desafios para avaliar a implantação de um "sistema sem muros”. Cadernos de Saúde Pública, Rio de Janeiro, v.20, p.S331-S336, 2004. Suplemento 2. 
HORTALE, V.A.; PEDROZA, M.; ROSA, M.L.G. Operacionalizando as categorias acesso e descentralização na análise de sistemas de saúde. Cadernos de Saúde Pública, Rio de Janeiro, v.16, n.1, p.231-239, 2000.

JULIANI, C.M.C. Organização do Sistema de Referência no Contexto do Sistema Único de Saúde. 1996. Dissertação (Mestrado) - Escola de Enfermagem, Universidade de São Paulo, São Paulo.

KEHRIG, R.T. Integralidade da Atenção à Saúde: suas expressões na organização tecnológica do trabalho em serviços locais de saúde. 2001. Tese (Doutorado em Saúde Pública) - Faculdade de Saúde Pública, Universidade de São Paulo, São Paulo.

LAPASSADE, G. A observação participante. In: As Microssociologias. Brasília, DF: Liber Livro Ed., 2005. p. 69-90.

LEVCOVITZ, E.; LIMA, L.D.; MACHADO, C.V. Política de saúde nos anos 90: relações intergovernamentais e o papel das Normas Operacionais Básicas. Ciência \& Saúde Coletiva, Rio de Janeiro, v.6, n.2, p.269-293, 2001.

LOPES, A.R. Diretrizes para o Planejamento de Serviços de Saúde Secundários e Terciários em Cardiopatia e Gravidez no Sistema Único de Saúde. 1996. Tese (Doutorado em Saúde Pública) - Faculdade de Saúde Pública, Universidade de São Paulo, São Paulo.

MAEDA, S.T. Gestão de Referência e Contra Referência na Atenção ao Ciclo Gravídico Puerperal: a realidade do Distrito de Saúde do Butantã. 2002. Tese (Doutorado em Saúde Pública) - Faculdade de Saúde Pública, Universidade de São Paulo, São Paulo.

MARQUES, R.M.; MENDES, A. A política de incentivos do Ministério da Saúde para a atenção básica: uma ameaça à autonomia dos gestores municipais e ao princípio da integralidade? Cadernos de Saúde Pública, Rio de Janeiro, v.18, p.163-171, 2002. Suplemento.

MATTOS, R.A. Os sentidos da integralidade: algumas reflexões acerca de valores que merecem ser defendidos. In: PINHEIRO, R.; (Org.). Os Sentidos da 
Integralidade na atenção e no cuidado à saúde. Rio de Janeiro: UERJ, IMS/Abrasco, 2001. p. 39-64.

MATTOS, R.A. A integralidade na prática (ou sobre a prática da integralidade).

Cadernos de Saúde Pública, Rio de Janeiro, v.20, n.5, p.1411-1416, 2004.

MENDES, E.V. O processo social da distritalização da saúde. In: (Org.).

O Distrito Sanitário: o processo social de mudança das práticas sanitárias do

Sistema Único de Saúde. São Paulo: Ed. Hucitec/Abrasco, 1993. p. 93-158.

MERHY, E.E. Em busca da qualidade dos serviços de saúde: os serviços de porta aberta para a saúde e o modelo tecno-assistencial em defesa da vida. In: CECILIO, L.C.O. (Org.). Inventando a Mudança na Saúde. São Paulo: Ed. Hucitec, 1994. p. 117-160.

MINAYO, M.C.S. Fase de análise ou tratamento do material. In: $\mathbf{O}$

Desafio do Conhecimento. Pesquisa qualitativa em saúde. $4^{\text {a }}$. ed. São Paulo: Ed. Hucitec, 1996. p. 197-247.

PINHEIRO, R. As práticas do cotidiano na relação oferta e demanda dos serviços de saúde: um campo de estudo e construção da integralidade. In: ; MATTOS, R.A. (Org.). Os Sentidos da Integralidade na atenção e no cuidado à saúde. Rio de Janeiro: UERJ, IMS/Abrasco, 2001. p. 65-112.

RAMOS, R. A Integração Sanitária: doutrina e prática. 1972. 366 p. Tese (Livre Docência em Saúde Pública) - Faculdade de Saúde Pública, Universidade de São Paulo, São Paulo.

SANTOS, N.R. Organização da atenção à saúde: é necessário reformular as estratégias nacionais de construção do "Modelo SUS"? Saúde em Debate, Rio de Janeiro, v.28, n.68, p.279-288, 2004.

SÃO PAULO. Secretaria Municipal de Saúde. Estrutura da SMS. Disponível em: $<$ http://portal.prefeitura.sp.gov.br/secretarias/saude/organizacao/estrutura > Acesso em: 21 mar. 2005. 
SCATENA, J.H.G.; TANAKA, O.Y. Os instrumentos normatizadores (NOB) no processo de descentralização da saúde no município de Itajaí. Saúde e Sociedade, São Paulo, v.10, n.2, p.47-74, 2001.

SILVA, S.F. Municipalização da Saúde e Poder Local: sujeitos, atores e políticas. São Paulo: Ed. Hucitec, 2001.

SILVA, P.L.B. Serviços de saúde: o dilema do SUS na nova década. São Paulo em Perspectiva, v.17, n.1, p. 69-85, 2003.

SILVA, V.C. O Processo de Implantação do Sistema Integrado de Serviços de Saúde em Vitória - ES: contribuição à discussão da integralidade na atenção à saúde. 2004. Dissertação (Mestrado em Saúde Pública) - Escola Nacional de Saúde Pública - Fiocruz, Rio de Janeiro.

TANAKA, O.Y.; MELO, C. Avaliação de Programas de Saúde do Adolescente: um modo de fazer. São Paulo: EDUSP, 2001.

TANAKA, O.Y. (Coord.), PINTO, N.R.S.; SPEDO, S.M. O Processo de (Re)Construção do Sistema Único de Saúde no Município de São Paulo. Uma avaliação sobre a incorporação do princípio da integralidade na política municipal de saúde [Projeto de pesquisa apresentado à Fapesp - auxílio à pesquisa]. São Paulo: FSP-USP, jun. 2005. [mimeo]

UGALDE, A.; HOMEDES, N. La descentralización de los servicios de salud: de la teoria a la práctica. Salud Colectiva, Buenos Aires, v.4, n.1, p.31-56, ene/abr, 2005. VIANA, A.L. Abordagens metodológicas em políticas públicas. RAP - Revista de Administração Pública, Rio de Janeiro, v.30, n.2, p.5-43, 1996.

VIANA, A.L.A. et al. Descentralização no SUS: efeitos da NOB-SUS 01/96. In: NEGRI, B.; VIANA, A.L.A. (Org.). O Sistema Único de Saúde em dez anos de desafio. São Paulo: Sobravime/Cealag, 2002. p. 471-488.

VIANA, A.L.A.; LIMA, L.D.; OLIVEIRA, R.G. Descentralização e federalismo: a política de saúde em novo contexto - lições do caso brasileiro. Ciência \& Saúde Coletiva, Rio de Janeiro, v.7, n.3, p.493-507, 2002. 
WEISS, C.H. Evaluation: methods for studying programs and policies. $2^{\text {nd }}$ ed. Upper Saddle River: Prentice Hall, 1998.

YIN, R.K. Estudo de Caso: planejamento e métodos. Tradução de D. Grassi. $3^{\mathrm{a}}$ ed. Porto Alegre: Bookman, 2005. 